FÁBIO IZUMI

PRODUÇÃO E CARACTERIZAÇÃO DE FILMES FINOS AMORFOS PARA APLICAÇÕES EM DISPOSITIVOS FOTÔNICOS 
FÁBIO IZUMI

\section{PRODUÇÃO E CARACTERIZAÇÃO DE FILMES FINOS AMORFOS PARA APLICAÇÕES EM DISPOSITIVOS FOTÔNICOS}

Dissertação apresentada à Escola

Politécnica da Universidade de São Paulo para a obtenção do título de Mestre em Engenharia.

Área de concentração:

Microeletrônica

Orientador:

Prof. Dra. Luciana Reyes Pires Kassab

São Paulo 
Um homem não é outra coisa senão o que faz de si mesmo

Jean-Paul Sartre 


\section{AGRADECIMENTOS}

À professora-orientadora, pelo apoio e incentivo ao trabalho.

Ao CNPq pela bolsa de Mestrado concedida.

À FATEC-SP e à Poli-USP pela possibilidade de realizar o trabalho

Aos alunos do Laboratório de Tecnologia em Materiais Fotônicos e Optoeletrônicos, e do Laboratório de Vidros e Datação que muito auxiliaram nos procedimentos.

Ao Prof. Dr. José Roberto Martinelli do IPEN-SP pelas realização das medidas de EDX.

Ao Prof. Dr. Acácio Siarkowski pelas colaboração na realização das medidas de perfilometria e elipsometria.

À Sra Simone P. de Toledo, do IFUSP, pelas realização das medidas de microscopia eletrônica de transmissão

Ao Prof. Davinson M. da Silva pela colaboração nas medidas de difração de raio-X.

Aos Profs. Davinson M. da Silva e Vanessa Cacho, e ao colega Leonardo Bomtempo pela ajuda na deposição dos filmes finos.

Aos demais colegas do Laboratório de Sistemas Integráveis (LSI-EPUSP) e do Laboratório de Tecnologia de Materiais Fotônicos e Optoeletrônicos (Fatec-SP) pelo auxílio em meus trabalhos. 


\section{RESUMO}

O presente trabalho possui como objetivo o estudo das propriedades dos filmes finos amorfos para aplicações em dispositivos fotônicos. Foram produzidos, por meio da técnica sputtering, filmes finos de telureto BWT, a partir de alvos cerâmicos com composição em peso de 54,6 $\mathrm{TeO}_{2}-22,6 \mathrm{WO}_{3}-22,8 \mathrm{Bi}_{2} \mathrm{O}_{3}$. A escolha dos vidros $\mathrm{BWT}$ se deve às qualidades elétricas e ópticas dos teluretos. Filmes com nanopartículas de ouro foram produzidos e a nucleação das nanopartículas se deu por tratamento térmico. Os filmes produzidos foram caracterizados pelas técnicas de elipsometria, perfilometria, espectrometria de fluorescência de raios-X por energia dispersiva, difração de raios-X, transmissão, absorção e microscopia eletrônica de transmissão e de varredura. Como etapa, final foram produzidos guias de onda do tipo "rib" por meio de procedimentos de corrosão e litografia, a fim de que fossem testados guiamentos de luz em $632,8 \mathrm{~nm}$ e em $1050 \mathrm{~nm}$. Foram usados diferentes fluxos de $\mathrm{SF}_{6}$ para corrosão dos filmes, resultando em guias de diferentes valores de $\mathrm{h}_{\text {_core }}$. Os guias com h_core de 63 e $82 \mathrm{~nm}$ apresentaram perda de no máximo 3,5 dB/cm para guiamento em 632,8 e $1050 \mathrm{~nm}$ em guias com larguras que variaram de 6 a $10 \mu \mathrm{m}$. As simulações realizadas mostraram guiamento multímodo para todos os casos. O material BWT é, portanto, promissor para aplicações em dispositivos fotônicos.

Palavras-chave: filmes finos, vidro, BWT, fotônica, sputtering, guia de onda. 


\begin{abstract}
The objective of this present work is study the properties of amorphous thin films for applications in photonic devices. Thin films of tellurite BWT were produced by sputtering technique using targets whose compositions in weight are $54.6 \mathrm{TeO}_{2}-22.6 \mathrm{WO}_{3}-22.8$ $\mathrm{Bi}_{2} \mathrm{O}_{3}$. BWT was chosen due to the electrical and optical properties of tellurite. Films with gold nanoparticles were produced and the nucleation of the nanoparticles was obtained by heat treatment. Films were characterized by the techniques of elipsometry, perfilometry, energy dispersive X-ray spectroscopy, X-ray diffraction, absorption, transmission, scanning electronic and transmission electronic microscopies. The final step was production of BWT rib waveguides using lithography and reactive-ion etching in order to test light guiding at $632.8 \mathrm{~nm}$ and $1050 \mathrm{~nm}$. BWT rib waveguides were produced, using different flux of $\mathrm{SF}_{6}$ for the etching, resulting in waveguides with different values of h_core. Waveguides with 63 and $82 \mathrm{~nm}$ of $\mathrm{h}$-core presented maximum loss of $3,5 \mathrm{~dB} / \mathrm{cm}$ at $632.8 \mathrm{~nm}$ and $1050 \mathrm{~nm}$ wavelengths in guides with widths ranging from 6 to $10 \mu \mathrm{m}$. All simulations showed multimode guiding. The BWT material is a potential candidate for applications in photonic devices.
\end{abstract}

Keywords: thin films, glass, BWT, photonics, sputtering, waveguide. 


\section{LISTA DE ILUSTRAÇÕES}

FIG. 1 - SPUTTERING YIELD EM FUNÇÃO DO ÂNGULO DE INCIDÊNCIA DO ÍON SOBRE A SUPERFÍCIE DO ALVO [4]

FIG. 2 - EQUIPAMENTO PARA DEPOSIÇÃO DE FILMES FINOS POR SPUTTERING DA FATEC-SP. 21

Fig. 3 - DiAgRAMA DE UM ONDA PLANAR COM TRÊS CAMADAS COM ÍNDICES DE REFRAÇÃO N ${ }_{1}, \mathrm{~N}_{2}$ E N $\mathrm{N}_{3}$. A LUZ É GUIADA NO MEIO DE ÍNDICE N2. [17]

FIG. 4 - PRINCÍPIO FÍSICO DO CONFINAMENTO DE LUZ, SENDO $N_{2}>N_{l}, N_{3}[18]$ 27

Fig. 5 - Modos de PROPAGAÇÃo DE UM RAIO LUMINOSO EM UM GUIA DE ONDA: (A) MODO DE RADIAÇÃO; (B) MODO DE SUBSTRATO; (C) MODO GUIADO [2, 19]

FIG. 6 - DISPOSITIVO ÓPTICO INTEGRADO USADO COMO TRANSMISSOR/RECEPTOR 28

FIG. 7 - ILUSTRAÇÃO DAS CONFIGURAÇÕES UTILIZADAS POR GUIAS DE ONDA. CONFINAMENTO DO EIXO X: GUIAS “SLAB” DO TIPO STEP INDEX (A) E ÍNDICE GRADUAL (B). CONFINAMENTO LATERAL: “RAISED STRIP” (C), CANAL (D) E “RIB” (E) [21]

FIG. 8 - FORMAS DE CONVERSÃO ASCENDENTE: (A) POR AEE; (B) POR AEE E TRANSFERÊNCIA ENERGÉTICA ENTRE ÍONS; (C) POR EC [13]

FIG. 9 - ESQUEMA DO CAMPO EVANESCENTE VERTICAL PROVINDO DE UM SINAL ELETROMAGNÉTICO GUIADO, COM SUFICIENTE (A) E INSUFICIENTE (B) ESPESSURA DA CAMADA BUFFER [31] 35

FIG. 10 - A TAÇA DE LYCURGUS, QUANDO ILUMINADA EM SEU INTERIOR COM LUZ DE DETERMINADA FREQUÊNCIA, PASSA DA COLORAÇÃO VERDE (ESQ.) PARA UMA AVERMELHADA (DIR.), DEVIDO À AÇÃO DOS PLASMONS DE SUPERFÍCIE [33] 37

FIG. 11 - ESPECTRO DE ABSORÇÃO DE NPS DE OURO COM DIFERENTES TAMANHOS [34] 38

FIG. 12 - ABSORBÂNCIA DE NANOBARRAS DE OURO [34] 38

FIG. 13 - INTERFERÊNCIA DA FORMA DAS NPS NA POSIÇÃO DAS BANDAS DE ABSORÇÃO DOS PLASMONS SUPERFICIAIS, EM COLÓIDES COM NPS DE PRATA [36]

FIG. 14 - FLUXOGRAMA DA PREPARAÇÃO DOS ALVOS CERÂMICOS 
FIG. 17 - SISTEMA DE TRATAMENTO COM HOTPLATE E UV

FIG. 18 - CAMADA DE ISOLAÇÃO ÓPTICA PARA OS GUIAS DE ONDA FORMADA POR OXIDAÇÃO TÉRMICA 48

FIG. 19 - CAMADA DE GUIAMENTO (FILME BWT) DEPOSITADO POR SPUTTERING SOBRE A CAMADA DE ISOLAÇÃO $\left(\mathrm{SIO}_{2}\right)$

FIG. 20 - FotOGRAVAÇÃO DOS GUIAS ÓPTICAS SOBRE O FILME DE GUIAMENTO 51

FIG. 21 - LAYOUT DA MÁSCARA USADA PARA A FABRICAÇÃO DE GUIAS DE ONDA BWT 52

FIG. 22 - CORROSÃO E DEFINIÇÃO DOS GUIAS “RIB” NO FILME DE GUIAMENTO 53

FIG. 23 - ASPECTO DO PLASMA E DA BAINHA NO REATOR RIE [12] 54

FIG. 24 - APARELHO REATOR USADO NA CORROSÃO RIE 55

FIG. 25 - RESULTADO DA LIMPEZA E REMOÇÃO DO FOTORRESISTE PARA OS GUIAS BWT 56

FIG. 26 - ESQUEMA DE UM MICROSCÓPIO ELETRÔNICO DE VARREDURA. C1 E C2 SÃO AS LENTES CONDENSADORAS. A BOMBA TURBOMOLECULAR É RESPONSÁVEL PELA GERAÇÃO DO VÁCUO DENTRO DO CANHÃO ELETRÔNICO [38] 58

FIG. 27 - ESQUEMA DE UM MICROSCÓPIO ELETRÔNICO DE TRANSMISSÃO [51] 60

FIG. 28 - MONTAGEM EXPERIMENTAL EMPREGADA PARA O ACOPLAMENTO DO LASER E MEDIDAS DE ATENUAÇÃO ÓPTICA

Fig. 29 - PERFIL ESTRUTURAL UTILIZADO NA CARACTERIZAÇÃO DOS GUIAS DE ONDA [2, 31] 64

FIG. 30 - DESENHO ESQUEMÁTICO DO GUIA DE ONDA TIPO “RIB” USADO NA SIMULAÇÃO [31] 65

FIG. 31 - TRANSMITÂNCIA DE AMOSTRAS BWT FABRICADAS SEM OXIGÊNIO 66

FIG. 32 - ABSORBÂNCIA DE AMOSTRAS BWT FABRICADAS SEM OXIGÊNIO 66

FIG. 33 - TRANSMITÂNCIA DE AMOSTRAS BWT FABRICADAS COM OXIGÊNIO 67

FIG. 34 - ABSORBÂNCIA DE AMOSTRAS BWT FABRICADAS COM OXIGÊNIO 67

FIG. 35 - COMPARAÇÃO DAS ABSORBÂNCIAS DE AMOSTRAS BWT TRATADAS COM OXIGÊNIO (VERMELHO) E SEM OXIGÊNIO (PRETO). AMBAS AS AMOSTRAS FORAM TRATADAS POR 1H 68 
Fig. 36 - TRANSmitÂnCiA do BWT COM Au SEM tRATAMENTO, TRATAdo APENAS NO Hotplate A $340^{\circ} \mathrm{C}$ E TRATADO COM HOTPLATE E UV A $340^{\circ} \mathrm{C}$ SIMULTANEAMENTE

Fig. 37 - ABSORÇÃo ÓPTICA DAS AMOSTRAS DE BWT SEM TRATAMENTO, TRATADAS COM HOTPLATE A 340 C E TRATADAS COM CHAPA AQUECIDA (HOTPLATE) A 340 C E UV SIMULTANEAMENTE

FIG. 38 - DifRAÇÃO REFERENTE À AMOSTRA DE BWT MATRIZ FEITA APENAS COM ATMOSFERA DE ARGÔNIO E TRATADA POR 10H A $360 \mathrm{C}$.

FIG. 39 - ANÁliSE DA DIFRAÇÃO DE UMA AMOSTRA BWT PRODUZIDA COM O 2 E TRATADA POR 1H, FEITA PELO PROGRAMA PANALYTICAL

FIG. 40 - DIFRAÇÃO DO BWT+AU TRATADO 20H NO HOTPLATE COM UV 74

FIG. 41 - Microscopia ELETRÔNICA DE TRANSMISSÃo DO FRAGMENTO 1 DE FILME FINO DE BWT COM NANOPARTículas DE OURO TRATAdo 20H COM hotPlate. A IMAGEM DE DifRAÇÃo DE ELÉTRONS E O HISTOGRAMA REFERENTE À DISTRIBUIÇÃO POR TAMANHO DAS NANOPARTÍCULAS SÃO TAMBÉM MOSTRADOS 75

FIG. 42 - EDS DO FRAGMENTO 1 DO FILME BWT+AU TRATADO 20H COM HOTPLATE 76

Fig. 43 - Microscopia ELETRÔNICA DE TRANSMISSÃO DO FRAGMENTO 2 DE FILME FINO DE BWT COM

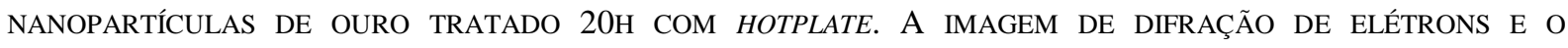
HISTOGRAMA REFERENTE À DISTRIBUIÇÃO POR TAMANHO DAS NANOPARTÍCULAS SÃO TAMBÉM MOSTRADOS 77

FIG. 44 - EDS DO FRAGMENTO 2 DO FILME BWT+AU TRATADO 20H COM HOTPLATE 77

Fig. 45 - Microscopia ElETRÔNICA DE TRANSMISSÃO DO FRAGMENTO 2 DE FILME FINO DE BWT COM

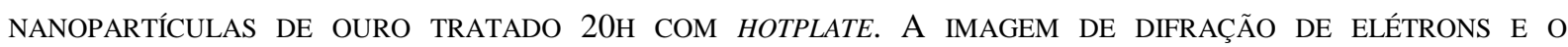
HISTOGRAMA REFERENTE À DISTRIBUIÇÃO POR TAMANHO DAS NANOPARTÍCULAS SÃO TAMBÉM MOSTRADOS

FIG. 46 - EDS DO FRAGMENTO 3 DO FILME BWT+AU TRATADO 20H COM HOTPLATE 79

FIG. 47 - IMAGEM DO GUIA DE ONDA PLANAR DE BWT DO TIPO “RIB” ANTES DA REMOÇÃO DO FOTORRESISTE. O GUIA É DE $6 \mu \mathrm{M}$ DE LARGURA . 80

FIG. 48- IMAGEM DO GUIA DE ONDA PLANAR DO TIPO “RIB” COM $5 \mu$ M DE LARGURA, APÓS REMOÇÃO DO FOTORRESISTE 80 
FIG. 49 - PERDAS POR PROPAGAÇÃo (EM DB/CM) NOS GUIAS DE ONDA BWT OBTIDOS APÓS LITOGRAFIA E CORROSÃO DO FILME COM 15 SCCM DE SF 6

FIG. 50 - PeRdas POR PROPAGAÇÃo (EM DB/CM) NOS GUIAS DE ONDA BWT OBTIDOS APÓS LITOGRAFIA E CORROSÃO DO FILME COM 25 SCCM DE SF 6 82

FIG. 51 - TRANSMISSÃO DE UM FEIXE DE LASER DE 632,8 NM EM UM GUIA BWT DE $9 \mu$ M DE LARGURA, PRODUZIDA UTILIZANDO 25 SCCM DE SF 6 PARA REMOÇÃO DO FILME

Fig. 52 - PERdAS POR PROPAGAÇÃo (EM DB/CM) NOS GUIAS DE ONDA BWT OBTIDOS APÓS LITOGRAFIA E CORROSÃO DO FILME COM 15 SCCM DE SF 6 , PARA COMPRIMENTO DE ONDA DE 1050 NM.

FIG. 53 - PERDAS POR PROPAGAÇÃo (EM DB/CM) NOS GUIAS DE ONDA BWT OBTIDOS APÓS LITOGRAFIA E CORROSÃO DO FILME COM 25 SCCM DE SF 6 , PARA UM FEIXE DE LASER DE 1050 NM 84

FIG. 54 - SIMULAÇÃO DOS MODOS DE PROPAGAÇÃO DO CAMPO ELÉTRICO NOS GUIAS DE ONDA BWT PRODUZIDOS COM 15 SCCM DE SF 6 PARA DIFERENTES W_CORE. O H_CORE DOS GUIAS É DE 63 NM ..... 85

FIG. 55 - SIMULAÇÃO DOS MODOS DE PROPAGAÇÃO DO CAMPO ELÉTRICO NOS GUIAS DE ONDA BWT PRODUZIDOS COM 25 SCCM DE SF6 PARA DIFERENTES W_CORE. O H_CORE DOS GUIAS É DE 82 NM 86

FIG. 56 - SIMULAÇÃO DOS MODOS DE PROPAGAÇÃO DO CAMPO ELÉTRICO NOS GUIAS DE ONDA BWT PRODUZIDOS COM 15 SCCM DE SF 6 PARA DIFERENTES W_CORE, EM COMPRIMENTO DE ONDA DE 1050 NM 87

FIG. 57 - SimULAÇÃO dOS MOdOS DE PROPAGAÇÃO DO CAMPO ELÉTRICO NOS GUIAS DE ONDA BWT PRODUZIDOS COM 25 SCCM DE SF 6 PARA DIFERENTES W_CORE, EM COMPRIMENTO DE ONDA DE 1050 NM

FIG. 58 - SimULAÇÃO DOS MOdOS DE PROPAGAÇÃO DO CAMPO ELÉTRICO NOS GUIAS DE ONDA BWT PRODUZIDOS COM 15 SCCM DE SF 6 PARA DIFERENTES W_CORE, EM COMPRIMENTO DE ONDA DE 1530 NM 89

FIG. 59 - SimULAÇÃO DOS MOdOS DE PROPAGAÇÃO DO CAMPO ELÉTRICO NOS GUIAS DE ONDA BWT PRODUZIDOS COM 25 SCCM DE SF 6 PARA DIFERENTES W_CORE, EM COMPRIMENTO DE ONDA DE 1530 NM 90

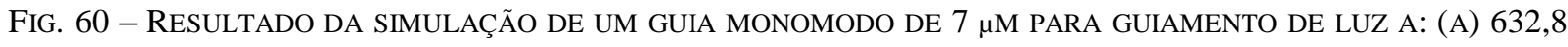
NM; (B) $1050 \mathrm{NM}$; (C) $1530 \mathrm{NM}$ 91

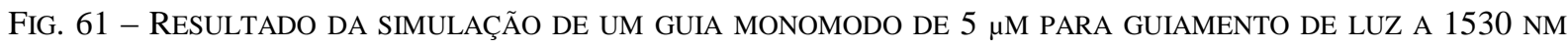




\section{LISTA DE TABELAS}

TABELA 1 - PARÂMETROS USADOS PARA A DEPOSIÇÃO DOS FILMES PRODUZIDOS

TABELA 2 - PARÂMETROS DE OXIDAÇÃO ADOTADOS NA OBTENÇÃO DO FILME $\mathrm{SIO}_{2}$ TÉRMICO

TABELA 3 - PARÂMETROS USADOS PARA A DEPOSIÇÃO DO FILME BWT USADO PARA OS GUIAS DE ONDA 50

TABELA 4 - PARÂMETROS DE CORROSÃO USADOS PARA OS GUIAS DE ONDA BWT 55

TABEla 5 - DescriÇÃO DAS DIMENSÕES dOS GUIAS DE ONDA BWT TIPO “RIB” MEDIDOS. A CAMADA DE COBERTURA (H_CLAD) CONSIDERADA FOI O AR

TABELA 6 - FILME DE BWT MATRIZ PRODUZIDA COM O 2 TRATADO $(1 \mathrm{H})$ 70

TABELA 7 - PoRCENTAgEM EM MASSA dos ElEMENTOS ObTIDOS PELO EDX. O VALOR TEÓRICO É DADO COMO REFERÊNCIA.

TABELA 8 - SPUTTER YIELD DOS ELEMENTOS PARA PLASMA DE AR [56, 57]

TABELA 9 - PICOS ENCONTRADOS NA DIFRAÇÃO DO FILME DE BWT ..... 72

TABELA 10 - PICOS ENCONTRADOS NO GRÁFICO BWT+AU 74

TABELA 11 - RESUltados DE H_CORE PARA GUIAS MONOMODOS, EM FUNÇÃO DO COMPRIMENTO DE ONDA DA LUZ GUIADA 


\section{LISTA DE ABREVIAÇÕES E SIGLAS}

BWT Óxido amorfo de bismuto, tungstênio e telúrio

PVD Physical Vapour Deposition

CVD Chemical Vapour Deposition

CNPq Conselho Nacional de Desenvolvimento Científico e Tecnológico

LVD Laboratório de Vidros e Datações

LSI Laboratório de Sistemas Integráveis

EPUSP Escola Politécnica da Universidade de São Paulo

USP Universidade de São Paulo

IF Instituto de Física

IPEN Instituto de Pesquisas Energéticas e Nucleares

FATEC Faculdade de Tecnologia de São Paulo

XRD X-Ray Diffraction

MET Microscopia eletrônica de transmissão

MEV Microscopia eletrônica de varredura

EDX Espectrometria de fluorescência de raios-X por energia dispersiva

AEE Absorção do estado excitado

EC Emissão cooperativa

DVD Digital Versatile Disc 
Plasmon de superfície

NP

Nanopartícula

TR

Terra-rara

$\mathrm{RF}$

Radio-frequência

IR

infravermelho

UV

ultravioleta

RIE

Reactive Ion Etching

CCD Charge-Coupled Device

TE

Polarização transversal elétrica 


\section{LISTA DE SÍMBOLOS}

n - índice de refração

n' - índice de refração não linear

$\mathrm{n}_{\text {Clad }}$ - índice de refração da camada de cobertura

$\mathrm{n}_{\text {Core }}$ - índice de refração da camada de guiamento

$\mathrm{n}_{\text {Buffer }}$ - índice de refração da camada de isolação

$\lambda$ - comprimento de onda

M - massa atômica

$h$ - constante de Planck

$\mathrm{M}_{\mathrm{alvo}}$ - massa atômica do alvo

$\mathrm{M}_{\mathrm{ion}}$ - massa atômica do íon

$\mathrm{S}$ - taxa de sputtering (sputtering yield)

E - energia

$\theta$ - ângulo de incidência

$\mu$ - permeabilidade magnética relativa do material

$\varepsilon$ - constante dielétrica relativa

$\alpha$ - constante de atenuação ou perda por propagação

$\beta$ - constante de propagação no modo guiado

W - largura do guia 
W_core - largura do núcleo de confinamento do guia de onda

H_buffer - Espessura da camada de isolação

H_sub - espessura do substrato

h_core - corrosão parcial para obter o confinamento no guia de onda

$\mathrm{d}$ - espessura da camada de guiamento

$p$ - constante de decaimento transversal

$k_{0}-$ constante de propagação no vácuo

$\omega$ - freqüência angular

$\mathrm{P}_{1}$ - intensidade do feixe em um ponto 1 do guia

$\mathrm{P}_{2}$ - intensidade do feixe em um ponto 2 do guia

$\mathrm{Z}_{1}$ - posição de um ponto 1 do guia

$\mathrm{Z}_{2}$ - posição de um ponto 2 do guia 


\section{SUMÁRIO}

1. INTRODUCÃO

2. REVISÃO BIBLIOGRÁFICA $r$

2.1. O PROCESSO DE SPUTTERING 20

2.1.1. DEPOSIÇÃO POR SPUTTERING 20

2.1.2. DEPOSIÇÃO POR CO-SPUTTERING 22

2.1.3. VANTAGENS DO SPUTTERING PARA DEPOSIÇÃO DE FILMES FINOS PRODUZIDOS A PARTIR DE ALVOS PRODUZIDOS COM ÓXIDOS DE METAL PESADO 22

2.2. FILMES FINOS AMORFOS NA FOTÔNICA 23

2.2.1. FILMES FINOS 23

2.2.2. FILMES FINOS DE $\mathrm{BI}_{2} \mathrm{O}_{3}-\mathrm{WO}_{3}-\mathrm{TEO}_{2}$ (BWT) 24

2.2.3. OS FILMES FINOS AMORFOS NOS DISPOSITIVOS EM FOTÔNICA 25

2.3. PRINCÍPIOS DOS GUIAS DE ONDA ÓPTICOS 26

2.4. GUIAS DE ONDA AMORFOS 30

2.5. GUIAS DE ONDA PASSIVOS E ATIVOS 31

2.6. Perdas Na PROPAGaÇão da LUZ 33

2.6.1. PERDAS POR ESPALHAMENTO 33

2.6.2. PERDAS POR ABSORÇÃO 34

2.6.3. PERDAS POR RADIAÇÃO 35

2.6.4. PERDAS POR ACOPLAMENTO 35

2.7. NANOPARTÍCULAS METÁLICAS E PLASMÔNICA 36

3. MATERIAIS E MÉTODOS

3.1. PRODUÇão DOS ALVOS 41

3.2. FABRICAÇÃO DOS FILMES

3.3. TRATAMENTOS TÉRMICOS DOS FILMES PARA NUCLEAÇÃO 46

3.4. PROCESSOS DE FABRICAÇÃO DOS GUIAS DE ONDA ÓPTICOS 47

3.4.1. LIMPEZA DAS LÂMINAS 47

3.4.2. OXIDAÇÃO TÉRMICA 48

3.4.3. DEPOSIÇÃO DO FILME BWT PARA OS GUIAS 49

3.4.4. TRATAMENTO TÉRMICO DO FILME BWT 50

3.4.5. FOTOGRAVAÇÃO DOS GUIAS ÓPTICOS POR LITOGRAFIA

3.4.6. CORROSÃO DOS FILMES DE BWT

3.4.7. REMOÇÃO DO FOTORRESISTE

3.5. TÉCNICAS DE CARACTERIZAÇÃO DOS FILMES E DOS GUIAS DE ONDA 55 
3.5.1. PERFILOMETRIA E ELIPSOMETRIA 56

3.5.2. MICROSCOPIA ELETRÔNICA DE VARREDURA (MEV) 58

3.5.3. MiCROSCOPIA ELETRÔNICA DE TRANSMISSÃO (MET) 60

3.5.4. ESPECTROMETRIA DE FLUORESCÊNCIA DE RAIOS-X POR ENERGIA DISPERSIVA $\begin{array}{ll}\text { (EDX) } & 60\end{array}$

3.5.5. ESPECTROMETRIA DE TRANSMISSÃO E ABSORÇÃO ÓPTICA NO UV-VIS 61

3.5.6. DIFRAÇÃO DE RAIOS-X (XRD) 61

3.5.7. CARACTERIZAÇÃO ÓPTICA DOS GUIAS

4. RESULTAdOS E DISCUSSÕES

4.1. MEDidAS DE TRANSMISSÃO E AbSORÇÃO ÓPTICA 66

4.1.1. MATRIZ BWT 66

4.1.2. BWT COM NANOPARTÍCULAS DE OURO 68

4.2. PERFILOMETRIA E ELIPSOMETRIA

4.3. ESPECTROMETRIA DE FLUORESCÊNCIA DE RAIOS-X 71

4.4. DIFRAÇÃO DE RAIOS-X 72

4.5. MICROSCOPIA ELETRÔNICA DE TRANSMISSÃO E DE VARREDURA 75

4.5.1. MICROSCOPIA ELETRÔNICA DE TRANSMISSÃO 75

4.5.2. MICROSCOPIA ELETRÔNICA DE VARREDURA 79

4.6. CARACTERIZAÇÃO ÓPTICA DOS GUIAS DE ONDA E SIMULAÇÕES 81

5. CONCLUSÕES E PERSPECTIVAS

6. SUGESTÕES PARA TRABALHOS FUTUROS

7. REFERÊNCIAS BIBLIOGRÁFICAS

APÊNDICE A - PARTICIPAÇÕES EM EVENTOS E PUBLICAÇÕES 100 


\section{INTRODUÇÃO}

O presente trabalho possui como primeiro objetivo o estudo das propriedades dos filmes finos amorfos de telureto com e sem nanopartículas de Au, para aplicações em dispositivos fotônicos utilizando comprimentos de onda de 632, 1050 e $1530 \mathrm{~nm}$. O estudo concentra-se no vidro de telureto BWT, cuja composição, em porcentagem de massa, é 54,6 $\mathrm{TeO}_{2}-22,6$ $\mathrm{WO}_{3}-22,8 \mathrm{Bi}_{2} \mathrm{O}_{3}$.

O segundo objetivo consiste na produção e caracterização passiva de guias de ondas do tipo "rib", visando aplicações futuras em $1530 \mathrm{~nm}$.

A escolha da composição BWT se deve às conhecidas características dos teluretos para aplicações em fotônica, como larga transmissão (desde o visível até o infravermelho médio), alto índice de refração linear e não linear, baixa energia de fônon [1]. A fotônica, como ciência da manipulação da luz como fonte de informações e dados, é um ramo extremamente promissor no campo da micro e nanotecnologia. Dentre os vários dispositivos fotônicos, os guias ópticos ganham destaque, devido à necessidade de transmitir sinais com eficiência a lugares com variadas distâncias, entre um transmissor e um modulador (ou receptor) dentro de um circuito integrado ou um local e outro distantes entre si por centenas ou milhares de quilômetros.

No campo das telecomunicações ópticas, os guias ópticos na forma planar ou canal estão ganhando destaque cada vez maior, devido à necessidade de miniaturização dos sistemas, transmissão de informações e velocidade na amplificação dos sinais. Assim, os guias planares favorecem a integralização reunindo os requisitos necessários aos atuais sistemas de telecomunicações [2].

O telureto é excelente hospedeiro para íons de terras-raras, para nucleação de nanopartículas metálicas e para fabricação de fibras ópticas. Há resultados recentes do grupo com vidros de telureto nucleados que nos mostraram aumento considerável da luminescência de íons de terras-raras. Em particular, a composição deste trabalho só foi estudada na literatura em vidros, não havendo resultados para filmes finos, o que motiva a pesquisa em questão. 
Os trabalhos foram motivados pelos resultados obtidos na Iniciação Científica [3], quando as propriedades do BWT começaram a ser analisadas.

Devido às propriedades apresentadas pelo BWT, foram feitos guias de onda planares passivos do tipo "rib" fabricados a partir dos filmes feitos com este material.

O capítulo 2 mostra a revisão bibliográfica associada ao projeto em questão.

A próxima etapa deste trabalho, exposta no capítulo 3, refere-se à metodologia, isto é, aos procedimentos necessários para a execução das tarefas pertinentes ao projeto. $\mathrm{Na}$ metodologia, abordamos as etapas de processo referentes à produção dos filmes finos e guias de onda, assim como as caracterizações e simulações das amostras descritas neste texto. As simulações visam verificar o tipo de guia de onda produzido em função de um comprimento de onda.

Em etapa posterior, no capítulo 4, mostramos os resultados das caracterizações e simulações acima referidas. Discussões sobre os resultados obtidos foram feitas no capítulo 5. 


\section{Revisão bibliográfica}

\subsection{O processo de sputtering}

\subsubsection{Deposição por sputtering}

O processo de sputtering é um dos métodos PVD de deposição usados para produção de filmes finos.

No sputtering mais utilizado, chamado de magnetron sputtering, é induzido um campo magnético de radiofrequência, tipicamente $13,56 \mathrm{MHz}$, entre o catodo (onde estão os alvos) e o anodo (onde estão os substratos por onde o filme será depositado). A natureza alternada do campo induz os íons e os elétrons a realizarem movimentos cíclicos, colidindo com os átomos do alvo. Quando os íons, dotados de carga positiva, são induzidos a dirigir-se aos alvos, os elétrons, com carga negativa, seguem trajetória oposta. Com a inversão do sinal do campo, as trajetórias invertem-se.

O gás utilizado para geração do plasma é o argônio, devido à sua apreciável massa atômica $\left(\mathrm{M}_{\mathrm{Ar}}=40\right.$ u.m.a.), pouca reatividade química e baixo custo de obtenção. Seus íons possuem energia suficiente para arrancar qualquer material durante o processo de sputtering.

O rendimento deste processo, ou sputtering yield (S), depende fortemente da massa do alvo $\left(\mathrm{M}_{\mathrm{alvo}}\right)$, da massa do gás ionizado $\left(\mathrm{M}_{\mathrm{ion}}\right)$, da energia fornecida (E) e do ângulo de incidência $(\theta)$ entre a trajetória do íon e a superfície do alvo, dada pela fórmula 3.1 [4]:

$$
S \alpha \frac{M_{\text {ion }}}{M_{\text {alvo }}} \frac{\ln E}{E} \cos \theta
$$

O sputtering yield máximo é obtido quando o ângulo entre a trajetória do íon e a superfície do alvo é próxima, mas não igual, a $90^{\circ}$ conforme a figura 1. 


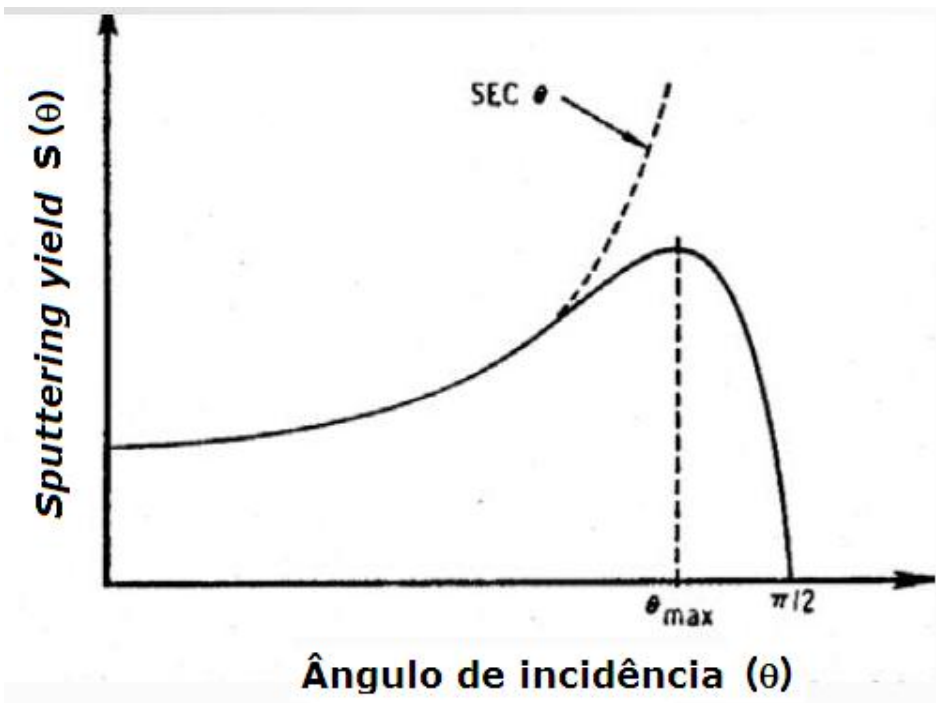

Fig. 1 - Sputtering yield em função do ângulo de incidência do íon sobre a superfície do alvo [4]

Quando há necessidade de fazer filmes como nitretos e óxidos, utiliza-se o sputtering reativo, empregando gases mais reativos do que o argônio, como o oxigênio $\left(\mathrm{O}_{2}\right)$. Esses gases interferem na taxa de deposição, pois reagem com as partículas arrancadas do alvo, antes que elas cheguem ao substrato.

A fig. 2 mostra o aparelho utilizado nas deposições, um EV-300 montado pela Prest Vácuo no Laboratório de Tecnologia de Materiais Fotônicos e Optoeletrônicos da Fatec-SP. Este aparelho foi adquirido com recursos do CNPq.

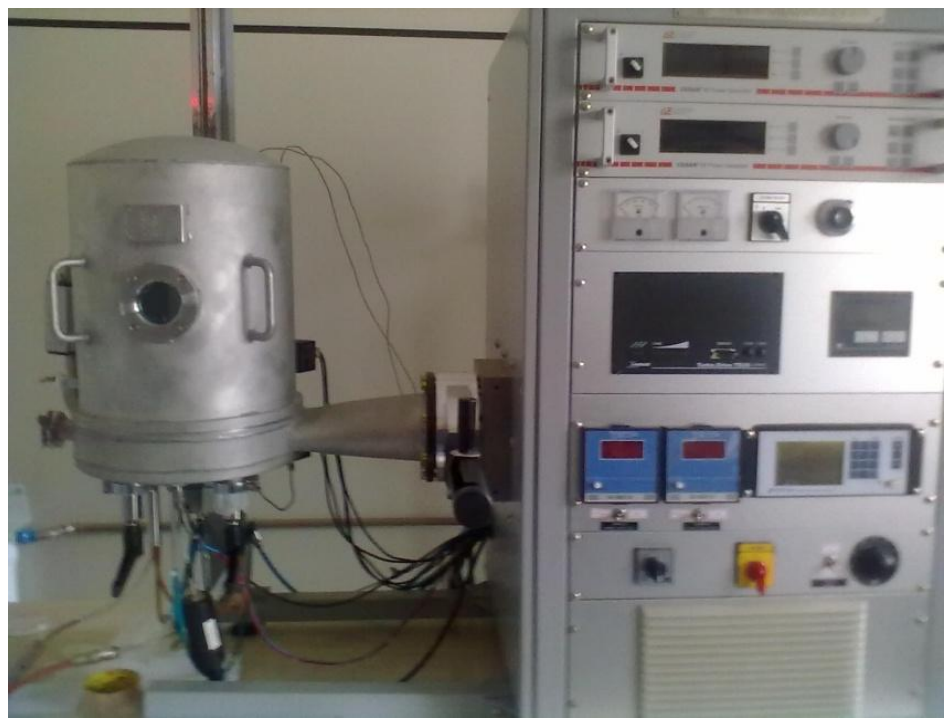

Fig. 2 - Equipamento para deposição de filmes finos por sputtering da Fatec-SP. 


\subsubsection{Deposição por co-sputtering}

O co-sputtering é a utilização de dois ou mais alvos, cada um sendo submetido a uma potência RF própria que permitem a deposição simultânea de diferentes materiais. Neste processo é possível operar com diferentes potências de RF em cada alvo de acordo com a necessidade. É comumente utilizado quando:

- deseja-se fazer filmes com estequiometria complexa quando não há possibilidade de empregar o sputtering reativo;

- for necessário produzir filmes dopados com elementos que não se misturam ou reagem com o material e acabam por formar nanopartículas, como é o caso do ouro, da prata e das terras-raras.

\subsubsection{Vantagens do sputtering para deposição de filmes finos produzidos a partir de alvos produzidos com óxidos de metal pesado}

Muitos filmes são produzidos em sputtering devido às suas qualidades: uniformidade, adequada cobertura de degrau, aderência do filme ao substrato e capacidade de depositar filmes com estequiometria complexa [5].

Os filmes feitos com sputtering tendem a reproduzir a mesma topografia do substrato, sendo, por isso, importante empregar substratos lisos e limpos. Nessas condições, os filmes apresentam rugosidade pouco significativa.

Existem algumas observações a respeito deste processo, considerando que foram usados óxidos de metais pesados:

- as taxas de deposição, que variam de acordo com a composição e natureza do material, foram relativamente altas;

- em certos casos o alvo pode degradar-se com a potência de RF empregada; neste caso é preciso então escolher valor adequado da potência usada. 
Cabe ainda ressaltar que a estequiometria e transparência podem ser controladas usando fluxo adequado de $\mathrm{O}_{2}$ durante a deposição.

Acrescenta-se ainda a possibilidade de tratamento térmico que, quando feito $a$ posteriori, pode causar aumento da transparência na região do visível. Ressalta-se ainda a possibilidade da incorporação de óxidos de terras-raras na forma trivalente nos referidos filmes desde que usado procedimento adequado: fluxo de $\mathrm{O}_{2}$ durante a deposição ou ainda ausência do mesmo conjugado a tratamento térmico, dependendo da matriz usada na produção do alvo.

As possibilidades acima apontadas demonstraram flexibilidade para uso da técnica sputtering para deposição de filmes finos produzidos a partir de alvos feitos à base de óxidos de metais pesados.

Estudos preliminares nos mostraram que outras técnicas de deposição não são adequadas quando usados alvos feitos à base de óxidos de metais pesados.

\subsection{Filmes finos amorfos na fotônica}

\subsubsection{Filmes finos}

Filmes finos são aqueles formados por um número restrito de camadas atômicas. Geralmente são considerados assim os filmes com espessura inferior a $1 \mu \mathrm{m}$, embora possam atingir até alguns micrômetros [6].

Dentre as várias aplicações na tecnologia moderna, estão circuitos integrados, mídias de gravação como DVD's e discos blu-ray, células solares, células de combustível, fibras ópticas, sensores, detectores e proteção contra agentes químicos [5].

Devido à sua reduzida espessura, os filmes finos possuem uma relação superfície/volume consideravelmente maior do que as estruturas maciças (bulkies) e mesmo do que os filmes espessos. Isso implica em uma maior incidência de átomos com ligações incompletas, por estarem na superfície dos filmes, e portanto serão mais reativos 
quimicamente com o meio externo. Requerem também maior cuidado com agentes mecânicos, principalmente quando os filmes finos não estão bem aderidos ao substrato, devido às diferenças estruturais, ou quando os filmes apresentam certa quantidade de falhas estuturais como contornos de grãos, resultado de problemas na formação (nucleação dos grãos, coalescência e aglutinação dos núcleos para formarem estruturas contínuas). Atrito, cisalhamento e impactos podem gerar falhas como fissuras e mesmo seccionamento de parte do material [6].

Os filmes finos amorfos diferem dos cristalinos pela estrutura, onde não há, como nos bulkies vítreos, um padrão para o ordenamento dos átomos. Quando apresentam transparência, alguns desses filmes possuem índices de refração consideráveis, o que os tornam indicados como transmissores e propagadores de ondas eletromagnéticas como a luz, os raios infravermelhos (IR) e ultravioletas (UV).

\subsubsection{Filmes finos de $\mathrm{Bi}_{2} \mathrm{O}_{3}-\mathrm{WO}_{3}-\mathrm{TeO}_{2}$ (BWT)}

Os filmes finos vítreos desenvolvidos no Laboratório de Tecnologia em Materiais Fotônicos e Optoeletrônicos da Fatec-SP com composição à base de germanato ou telureto apresentam características adequadas para aplicações em fotônica e optoeletrônica:

- índice de refração $(\mathrm{n} \geq 1,8$ a $\lambda=632 \mathrm{~nm})$ [7] consideravelmente superior ao do vidro de sílica, cujo índice de refração é de 1,46 para o mesmo comprimento de onda [8];

- baixas energias de fônon, entre $700 \mathrm{~cm}^{-1}$ e $900 \mathrm{~cm}^{-1}$, o que reduz as perdas por processos não radiativos [9];

- baixa reatividade química à maioria dos ácidos e bases; apenas o ácido fluorídrico os ataca em maior escala;

- considerável transparência destes vidros desde a região do visível até o infravermelho médio [10]; 
- resistência mecânica adequada, isto é, os vidros de germanato e telureto apresentam resistência a impactos maior, em geral, do que a dos vidros de sílica.

O material escolhido para o trabalho em questão apresenta a fórmula $70 \mathrm{TeO}_{2}-20 \mathrm{WO}_{3}$ - $10 \mathrm{Bi}_{2} \mathrm{O}_{3}$, em porcentagem molar [8].

Devido às características apresentadas, o BWT é um material potencialmente viável para aplicações em dispositivos fotônicos, como podemos ver a seguir.

\subsubsection{Os filmes finos amorfos nos dispositivos em fotônica}

A fotônica constitui um conjunto de estudos sobre a geração, transmissão, modulação, amplificação e detecção de ondas eletromagnéticas no espectro visível [11]. A geração corresponde à excitação energética de um elétron, durante a qual é fornecida energia suficiente para o elétron passar de um subnível a outro, gerando um fóton quando este mesmo elétron perde a energia e volta ao estado energético original. A transmissão se dá quando o espectro eletromagnético é propagado em um meio, graças aos mecanismos de difração, refração e reflexão ópticas, presentes em guias de ondas e fibras óticas. A modulação pode resultar em imposições para a luz se propagar, como o que ocorre na polarização por meio de lentes. A amplificação pode resultar no aumento da intensidade da luz por meio de interações com materiais com propriedades ópticas adequadas, principalmente se forem dopados com íons de terras-raras $[2,12,13]$. Por fim, a detecção corresponde ao uso de detectores de certas faixas de onda, para transformar a energia provinda desta em outras formas de energia.

Para executar o projeto de um dispositivo fotônico existem vários parâmetros, entre os quais $[12,14]$ :

- índice de refração linear (n), que determina a possibilidade de um feixe dentro do material fotônico não ter perdas por refração para o meio externo, pela lei de Snell (equaçao $3.2)$ :

$$
\mathrm{n}_{1} \operatorname{sen}\left(\theta_{1}\right)=\mathrm{n}_{2} \operatorname{sen}\left(\theta_{2}\right)(\text { Eq. 3.2) }
$$


Quanto maior o índice de refração em relação a um meio como o ar $(\mathrm{n}=1,0001)$, menor a possibilidade do feixe eletromagnético refratar para este meio de menor índice de refração;

- índice de refração não-linear (n'), determinado pelas propriedades de certos materiais de terem respostas ópticas não lineares; por exemplo, se um material tiver constante dielétrica não linear [14], isso afetará o índice de refração, conforme a fórmula (3.3.) [15]:

$$
n=\sqrt{\mu \varepsilon}(3.3 .)
$$

onde $\mu$ é a permeabilidade magnética relativa do material e $\varepsilon$ é a constante dielétrica relativa;

- energia de fônon, dada $\mathrm{em}^{-1}$, que indica a perda por decaimentos não radiativos. [16].

\subsection{Princípios dos guias de onda ópticos}

Guias de ondas são dispositivos que permitem a condução de luz de forma controlada, confinando-a em um determinado meio. O conceito básico de confinamento de onda é bastante simples. Um núcleo envolvido por uma cobertura de material com índice de refração menor do que o índice de refração do núcleo consegue confinar um feixe de luz por reflexão total interna. Este efeito provoca o confinamento da luz gerada, caso o índice de refração do núcleo seja suficientemente alto. Desse modo, é possível construir canais, ou guias, que conduzem a luz de um lugar para outro seguindo um caminho pré-definido [2].

Um guia de onda planar padrão tem três camadas:

- revestimento superior.

- núcleo ou de guiamento, com espessura $d$;

- isolação;

A Fig. 3 mostra um esquema de um guia planar [17]: 


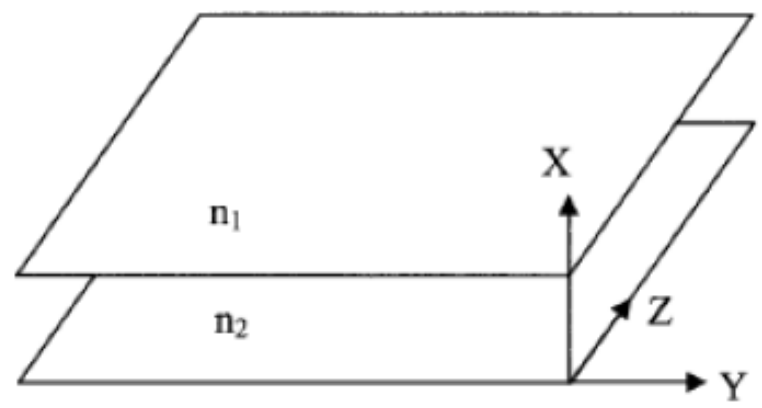

$\mathrm{n}_{3}$

Fig. 3 - Diagrama de um onda planar com três camadas com índices de refração $\mathrm{n}_{1}, \mathrm{n}_{2}$ e $\mathrm{n}_{3}$. A luz é guiada no meio de índice $\mathrm{n}_{2}$. [17]

$\mathrm{O}$ índice de refração das três camadas é $n_{1}, n_{2}, n_{3}$, respectivamente, e satisfaz às seguintes condições:

$$
n_{2}>n_{1}, n_{2}>n_{3}
$$

De acordo com a óptica geométrica o confinamento de luz no interior de um filme fino é descrito pela reflexão total em duas faces, como mostrado na fig. 4:

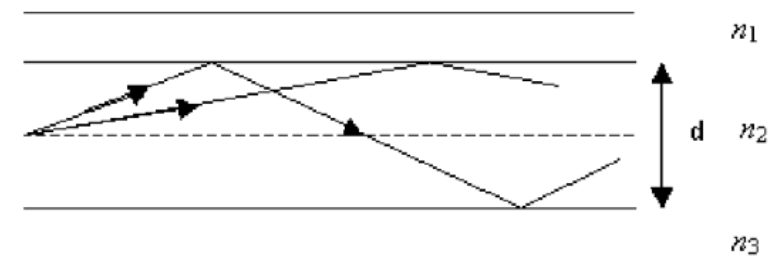

Fig. 4 - Princípio físico do confinamento de luz, sendo $n_{2}>n_{1}, n_{3}$ [18]

Um requisito importante para o entendimento da propagação de ondas eletromagnéticas em modos guiados é o conhecimento dos modos guiados.

Considerando que o meio 1, isto é, a camada de revestimento superior, é o ar, tem-se ainda que $n_{3}>n_{1}=1$. Isto implica na existência de dois ângulos limite $\theta_{1}$ e $\theta_{3}$ para as reflexões totais nas interfaces 1-2 do filme com o ar e 2-3 do filme com o substrato, respectivamente. Têm-se, portanto, três casos distintos, como representado na fig. 5: 


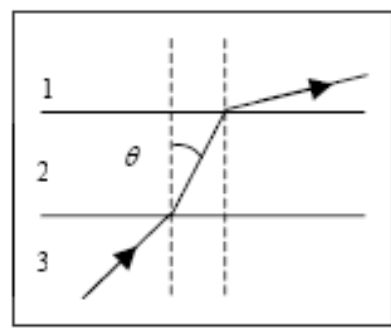

(a)

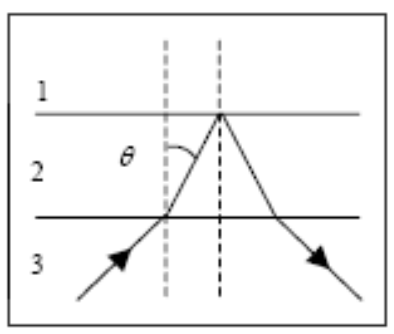

(b)

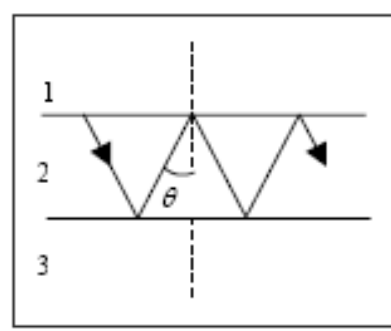

(c)

Fig. 5 - Modos de propagação de um raio luminoso em um guia de onda: (a) modo de radiação; (b) modo de substrato; (c) modo guiado [2, 19]

Para ângulos de incidência pequenos $\left(\theta<\theta_{1}, \theta_{3}\right)$, a luz incidente a partir do substrato é refratada de acordo com a lei de Snell e sai do guia como representado na fig. 5 (a). Este modo não confinado da luz é chamado de modo de radiação. Quando $\theta_{1}<\theta<\theta_{3}$, tem-se a situação descrita na fig. 5 (b) onde a luz é refratada na interface 3-2 e totalmente refletida na interface 2-1. Este é o modo de substrato. Finalmente, quando $\theta>\theta_{3}$ e $\theta>\theta_{1}$, ocorre reflexão total nas duas interfaces, fazendo com que haja confinamento da luz e, portanto, guiamento, conforme a fig. 5 (c). Este é o modo guiado.

Um dos guias de onda mais amplamente utilizados é a fibra óptica que é feita de dois cilindros de material dielétrico, de baixa perda, como o vidro. Apenas para exemplificar, na fig. 6 [20] é mostrado um guia de onda dentro de um circuito óptico integrado.

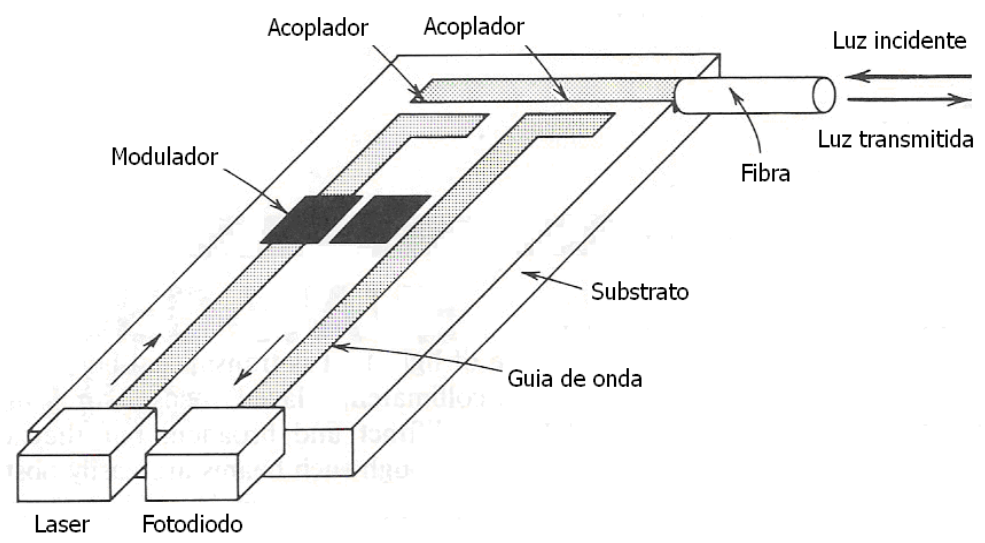

Fig. 6 - Dispositivo óptico integrado usado como transmissor/receptor

De acordo com a ilustração mostrada na fig. 6, a luz de entrada é acoplada em um guia de onda e dirigida em um fotodiodo onde é detectado. A luz do laser é guiada, modulada e acoplada em uma fibra. 
As configurações mais comuns utilizadas para o confinamento de luz em guias de onda, em ambas as direções transversais ao eixo de guiamento são apresentadas na Fig. 7 [21, 22].

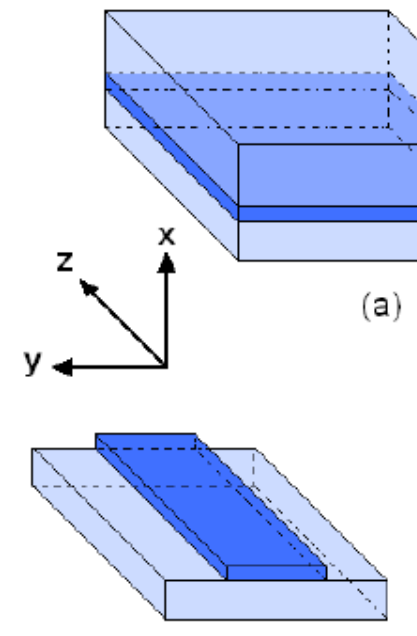

(c)

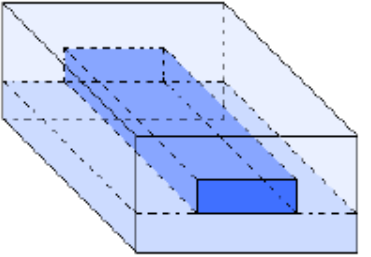

(d)

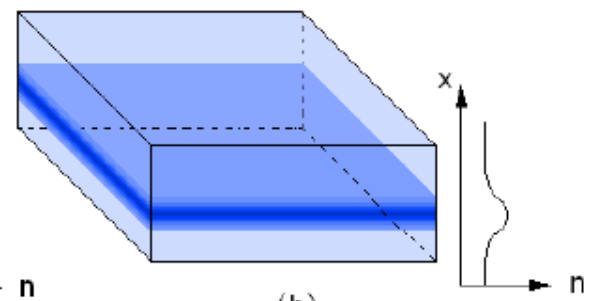

(b)

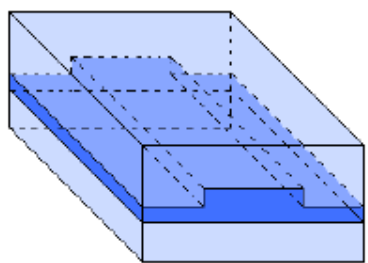

(e)

Fig. 7 - Ilustração das configurações utilizadas por guias de onda. Confinamento do eixo x: guias "slab" do tipo step index (a) e índice gradual (b). Confinamento lateral: "raised strip" (c), canal (d) e "rib" (e). [21, 22].

Nas figuras 7(a) e 7(b) são ilustrados guias do tipo "slab" do tipo "step index" e índice gradual, respectivamente. Nessas figuras, também são mostrados os perfis de índice de refração ao longo do eixo x. Os guias do tipo "slab" são estruturas ideais, compostas por camadas adjacentes, com diferentes espessuras e índices de refração. Essa estrutura é simétrica com relação ao eixo de propagação (eixo z, na figura) e a um dos eixos transversais ao eixo de propagação. Dessa forma, o perfil de índices só varia ao longo de uma direção (eixo x, neste caso). No caso dos guias "slab" do tipo "step index" convencional, temos uma camada com índice de refração maior que é adjacente a meios ou camadas de índice de refração menor. É dentro dessa camada de maior índice, que se costuma chamar de núcleo, que a luz se propaga.

Nos guias do tipo índice gradual, o índice de refração varia gradualmente de um valor maior na região do núcleo, para valores menores, na direção externa ao mesmo. As estruturas "slab" são muito úteis para a modelagem e simulação do comportamento eletromagnético, no projeto de guias de onda. Nas figuras 7(c), 7(d) e 7(e), são ilustradas algumas configurações utilizadas para realizar o confinamento lateral em guias de onda. Na Figura 7(c), é mostrada a configuração "raised strip", cuja lateral do núcleo é totalmente corroída de forma a definir as 
paredes laterais de um guia retangular. Na Figura 7(d), é mostrada a configuração canal, onde um núcleo formado por canal retangular fica envolto por meios de menor índice de refração. Na Figura 7(e), é mostrada a configuração do tipo "rib", cujo núcleo é parcialmente corroído para a definição das paredes laterais. Nesta, pode ou não haver deposição de uma cobertura sobre o núcleo.

Nos trabalhos feitos pelo grupo, foram utilizados guias do tipo "rib".

O "rib" é uma perturbação que pode ser criada, por exemplo, na camada guia de onda, ou em camadas acima ou abaixo desta, cuja finalidade é causar um aumento do índice efetivo do modo guiado nesta região. Isto previne que o campo eletromagnético guiado se espalhe lateralmente, melhorando o confinamento modal. O confinamento vertical da luz é obtido pelo princípio da reflexão interna total (RIT). Sendo assim, os índices refração das camadas de cobertura $\left(\mathrm{n}_{\text {Clad }}\right)$, guiamento $\left(\mathrm{n}_{\text {Core }}\right)$ e isolação $\left(\mathrm{n}_{\text {Buffer }}\right)$ devem seguir a seguinte relação: $\mathrm{n}_{\text {Core }}>\mathrm{n}_{\text {Clad }}$ e $\mathrm{n}_{\text {Core }}>\mathrm{n}_{\text {Buffer }}[22,23-26]$.

O confinamento lateral do feixe em guias tipo "rib" é obtido através da corrosão parcial do filme de guiamento, diminuindo o valor do índice de refração efetivo $\left(N_{\text {eff }}\right)$ nas áreas laterais ao guia.

As condições de confinamento determinam os modos de propagação no guia de onda. Os modos de propagação são os perfis característicos de distribuição espacial da onda eletromagnética guiada na estrutura e são determinados matematicamente por métodos numéricos desenvolvidos para a óptica integrada.

Para os guias "rib" existe um programa de simulação, o Selene 3.2 da BBV Software 3.2 [27], que possibilita a classificação dos guias em multímodo ou monomodo, e que foi usado no presente trabalho.

\subsection{Guias de onda amorfos}

Embora a fibra óptica seja um tipo especial de guia de onda, geralmente guias de onda referem-se a circuitos ópticos integrados em substratos. O conceito de guia de onda óptico veio na década de 1960 [17]. 
Com o rápido desenvolvimento dos sistemas de comunicações ópticas, houve pesquisas a respeito dos guias de onda amorfos, que mostraram ter desempenho altamente satisfatório.

Um guia óptico é na realidade a junção de três ou mais filmes finos, composto basicamente de um substrato, uma camada de isolação, uma camada de guiamento ("core") e uma camada de revestimento superior. Materiais para fabricação de guias de onda amorfos foram amplamente pesquisados, tanto os vidros de sílica quanto os vidros de multicomponentes (óxidos variados). Vários métodos foram desenvolvidos para fabricar os filmes finos componentes das guias, como CVD, troca iônica, sol-gel e sputtering.

A função primordial dos guias de onda amorfos convencionais é guiar e dividir o sinal luminoso. Outras utilidades, porém, vem sendo exploradas, expandindo consideravelmente a gama de aplicações. Eles podem ser usados, por exemplo, como comutadores ópticos ("switches") e filtros de frequência ajustável. Existem pesquisas no sentido de aplicar esses materiais em chips de amplificadores de sinais ópticos e moduladores eletro-ópticos. [17].

\subsection{Guias de onda passivos e ativos}

Os guias de onda amorfos podem ser divididos em passivos e ativos. Um guia é denominado passivo quando sua função é acoplar, dividir e ramificar a onda, como ocorre na grande maioria das fibras ópticas. Os guias ativos são formados de materiais com características não lineares que acabam por gerar ganhos ópticos.

Guias de onda ativos são formados a partir da deposição de vidros dopados com íons de terras-raras em substratos de Si. Os ganhos ópticos acontecem devido à excitação dos elétrons dos terras-raras, cujo subnivel mais energético é o 4f, quando um ou mais fótons provenientes da fonte ou de outros íons excitam os elétrons, os quais, em seguida, perdem a energia adquirida por meio da liberação de um novo fóton $[2,12,13]$. Este fenômeno é chamado de conversão ascendente [13, 28].

O processo de conversão ascendente pode acontecer de algumas formas. No espectro visível, três delas são significativas, conforme a fig. 8 [13]. 
No primeiro caso, mostrado na fig. 8 (a), correspondente ao processo de absorção do estado excitado (AEE), um íon em estado fundamental é excitado a um nível intermediário pela absorção de um fóton com energia ressonante à diferença entre dois níveis energéticos. A partir daí, a absorção de outro fóton leva este íon a um nível maior de energia em relação ao intermediário. Quando este íon volta ao seu estado fundamental, ele libera um fóton de maior energia e menor comprimento de onda. [28]

O segundo caso, mostrado na fig. 8 (b), é similar ao primeiro, porém há o envolvimento de um segundo íon, responsável pela liberação de um fóton para o íon vizinho em um estágio intermediário de energia. Logo, este íon mais energizado, ao voltar para o seu estado fundamental, libera um fóton mais energético.

Já o último caso, correspondente à fig. 8 (c), é mais raro por depender da interação coulombiana entre os íons e da distância entre eles; neste caso, dois íons recebem energia e são promovidos para um estado intermediário, retornando a um estado fundamental simultaneamente, liberando um único fóton com a energia recebida dos dois íons. Trata-se do processo de emissão cooperativa (EC). [28]

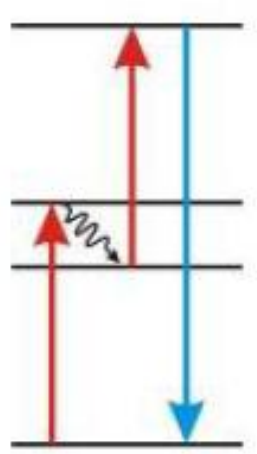

(a)

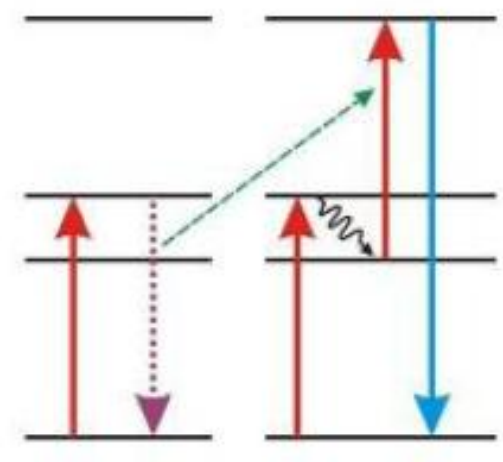

(b)

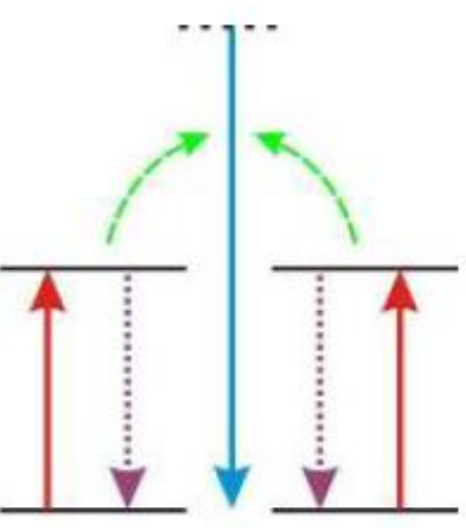

(c)

Fig. 8 - Formas de conversão ascendente: (a) por AEE; (b) por AEE e transferência energética entre íons; (c) por EC [13]

A grande maioria dos estudos relacionados aos guias de onda ainda estão voltados aos dispositivos passivos, e há uma quantidade considerável de trabalhos científicos a respeito de guias de onda em circuitos integrados, como o uso em chips fotônicos [29]. 


\subsection{Perdas na propagação da luz}

Em qualquer guia de onda, seja ele passivo ou ativo, existem as perdas de propagação, que podem ser:

- por espalhamento;

- por absorção;

- por radiação;

- por acoplamento

A soma destas perdas, apresentadas nos itens seguintes, constitui a atenuação no guiamento $[22,23]$.

\subsubsection{Perdas por espalhamento}

As perdas por espalhamento acontecem pelas imperfeições presentes no interior ou na superfície do filme, causadas por fatores como defeitos no filme vítreo e variações em sua composição.

O espalhamento de luz ocorre quando alguns fótons do feixe de luz incidente encontram estas irregularidades que desviam o seu ângulo de propagação. Estes fótons acabam por sair do modo guiado, provocando uma diminuição na intensidade da luz propagada. Efeitos como este interferem negativamente no confinamento da luz no guia.

A fonte predominante de espalhamento no guia óptico está localizada nas interfaces, associadas às irregularidades dos filmes depositados. A atenuação por espalhamento $\left(\alpha_{E}\right)$ é diretamente proporcional ao quadrado da rugosidade $(\sigma)$, de acordo com a equação (3.4.) a seguir [30]: 


$$
\propto_{E}=4(\beta \sigma)^{2} \frac{\cos ^{\mathrm{s}}(\theta) / \sin (\theta)}{W+^{2} / p}(3.4 .)
$$

onde $\beta$ é a constante de propagação no modo guiado, W é a largura do "rib", $\theta$ é o ângulo de propagação do guia e $p$ é a constante de decaimento transversal (vetor de onda transversal) dado por:

$$
p=\sqrt{\beta^{2}-\left(k_{0} n\right)^{2}}(3.5 .)
$$

onde $k_{0}$ é a constante de propagação no vácuo e $n$ é o índice de refração do filme em que ocorre o decaimento.

De acordo com Deri [30], a atenuação por espalhamento é diretamente proporcional à diferença entre os índices de refração entre a região de confinamento ("core") e as regiões de decaimento do modo de propagação (“clad”, "buffer" e laterais do “"rib"”), ou seja, a redução no contraste do índice de refração reduz o efeito de espalhamento, melhorando o casamento de impedâncias entre os meios que compõem a interface.

As perdas por espalhamento predominam nos guias de onda feitos a partir de materiais dielétricos, como é o caso da maioria dos vidros, variando de 0,5 a $5 \mathrm{~dB} / \mathrm{cm}$.

\subsubsection{Perdas por absorção}

Ocorrem em materiais que absorvem parte da radiação usada na propagação. Em materiais dielétricos cuja presença de contaminantes é bem controlada, a absorção é insignificante.

O guia de onda é fabricado a partir de um substrato de silício ( $\mathrm{Si}$ ) monocristalino. Devido ao alto índice de refração e também de absorção no visível, é necessária a utilização de um filme espesso de $\mathrm{SiO}_{2}$ antes da deposição do filme de guiamento (“core”), para a isolação do campo evanescente do modo guiado, como mostra a fig. 9 [31]. Na fig. 9 (A), o substrato está isolado do filme de guia de onda por uma camada dielétrica com espessura suficiente para minimizar o campo evanescente (radiação desviada do filme de guiamento 
para o substrato, chamada de "leaking loss"). Na fig. 9 (B), a camada de "buffer" possui espessura insuficiente para evitar o "leaking loss";

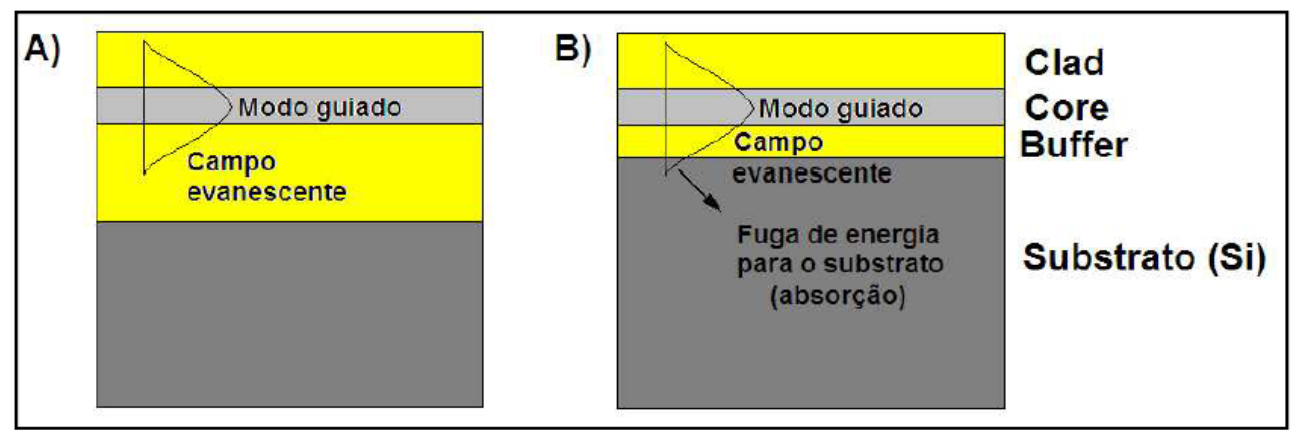

Fig. 9 - Esquema do campo evanescente vertical provindo de um sinal eletromagnético guiado, com suficiente (A) e insuficiente (B) espessura da camada buffer [31]

Os modos que se propagam em guias de ondas, onde o substrato apresenta índice de refração maior do que as demais camadas são normalmente classificados como modos vazantes ou "leaky modes" [22].

\subsubsection{Perdas por radiação}

Este tipo de perda envolve a diminuição da energia do modo guiado devido à probabilidade de alguns fótons escaparem do filme do guia de onda na interface filmesubstrato e filme-ar. Torna-se relevante em sistemas com baixa eficiência de confinamento de luz. O confinamento do feixe luminoso dentro do guia de onda (comprimento de onda da luz maior do que a espessura do guia) faz com que parte dele se propague nas interfaces, originando ondas evanescentes [2].

\subsubsection{Perdas por acoplamento}

Para acoplar luz em um guia de onda devemos focalizar a luz na extremidade do guia em um ângulo de incidência apropriado. $\mathrm{O}$ acoplamento depende não só deste ângulo mas das 
espessuras e dos índices de refração das camadas. A luz pode ser confinada e se propagar na direção do guia ou sobre uma superfície mas também pode ser atenuada por absorção no sistema [32]

\subsection{Nanopartículas metálicas e plasmônica}

As nanopartículas metálicas, ou NPs, conforme estudos feitos nos últimos anos, são capazes de absorver luz e transformar a energia eletromagnética em energia cinética dos elétrons livres pertencentes a estas nanopartículas. Esta energia cinética é basicamente oscilatória, que se torna coerente sob a ação de um campo eletromagnético. Por sua vez, este fenômeno é denominado plasmon de superfície (PS) [2, 12, 13, 33].

Dá-se o nome de plasmônica o estudo das interações dos diversos tipos de NPs com a luz. Estas interações variam conforme:

- a natureza das NPs (ouro, prata, cobre, platina e outros metais "nobres");

- o tamanho das NPs;

- o formato das NPs;

- o ambiente onde as NPs estão inseridas.

Os PS manifestam-se apenas em certas bandas de energia, correspondentes a uma frequência de ressonância. A energia não absorvida é liberada sob forma de energia eletromagnética. Este fenômeno foi explorado desde a Antiguidade, tendo como exemplo a Taça de Lycurgus, feita em Roma no séc. IV e exposta no British Museum de Londres [33], conforme a fig. 10 abaixo. Naquela época, as propriedades eram exploradas empiricamente e não se conheciam as propriedades dos plasmons de superfície. 

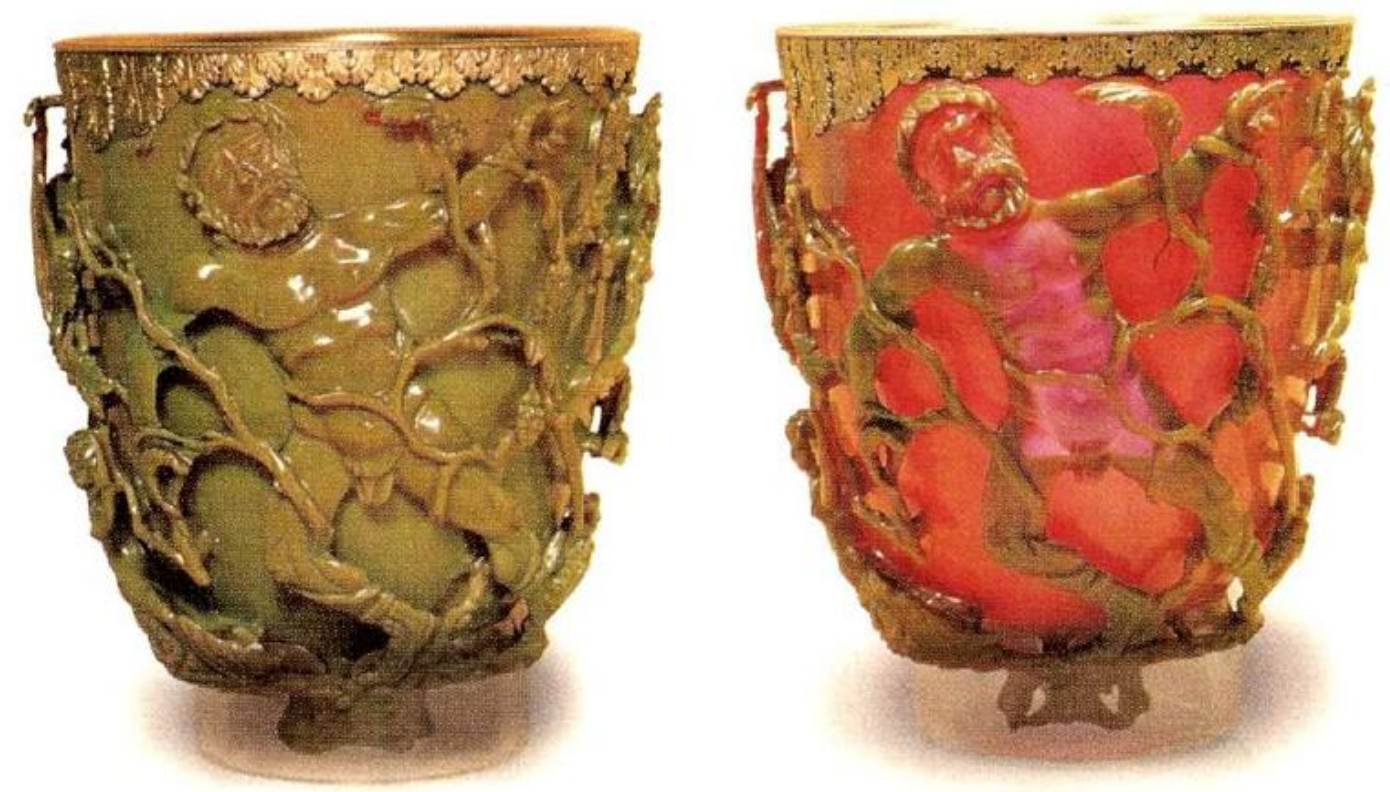

Fig. 10 - A taça de Lycurgus, quando iluminada em seu interior com luz de determinada frequência, passa da coloração verde (esq.) para uma avermelhada (dir.), devido à ação dos plasmons de superfície [33] .

Estes fenômenos foram estudados de forma sistemática por Gustav Mie (1869-1957), físico alemão, a partir de 1908, a partir da interação do ouro. Sua teoria, a partir das equações de Maxwell, relaciona o volume e a função dielétrica (tanto a real quanto a imaginária, sendo $\left.\varepsilon=\varepsilon_{1}+i \varepsilon_{2}\right)$ das NPs com a função dielétrica do meio isolante e a frequência angular $(\omega)$ da radiação incidente, correspondente à ressonância dos elétrons livres das NPs [34]. Mie e outros estudiosos da plasmônica notaram que o fenômeno ocorria não só com o ouro, mas diversos metais de transição, cujo subnível mais energético é $d$ [12]. Nos demais elementos, o plasmon não se manifesta na faixa do visível.

A literatura informa que [34, 35]:

- Para partículas extremamente pequenas (<25 nm para ouro), o deslocamento do pico da banda de absorção dos PS é pequena. No entanto, um alargamento do pico é observado.

- Para partículas maiores (> $25 \mathrm{~nm}$ para ouro), o pico da banda de absorção dos PS apresenta deslocamento para regiões de maior comprimento de onda, em direção ao vermelho. A fig. 11 ilustra esse comportamento para uma série de partículas de ouro com diferentes dimensões. 
- Para NPs com formato de barras, a banda de plasmon se dividiu em duas, correspondendo à oscilação dos elétrons livres no sentido longitudinal e transversal do eixo das nanobarras. A fig. 12 ilustra esse comportamento.

- O modo ressonante transverso possui comportamento semelhante às NPs, mas o modo longitudinal possui um expressivo deslocamento para regiões de maior comprimento de onda, que possui forte dependência da relação entre comprimento e espessura da nanobarra [34].

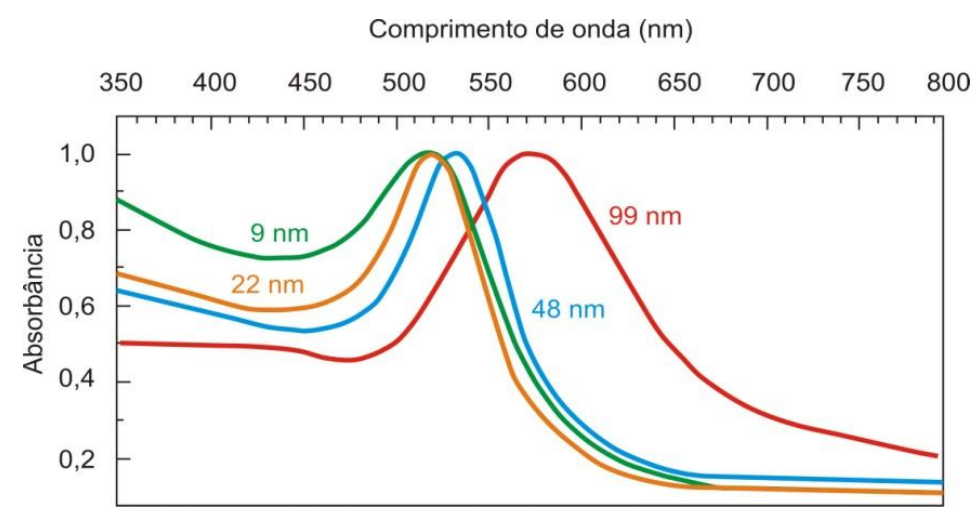

Fig. 11 - Espectro de Absorção de NPs de ouro com diferentes tamanhos [34].

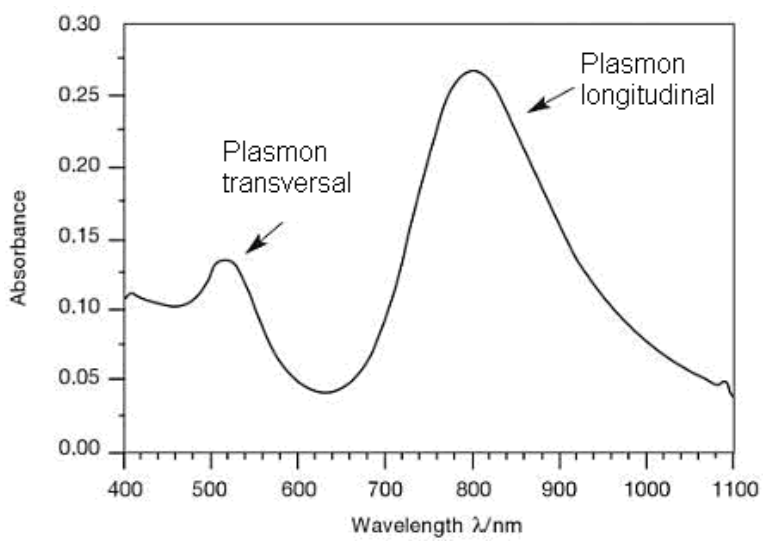

Fig. 12 - Absorbância de nanobarras de ouro [34].

A fig. 13 apresenta a interferência do formato das NPs de prata no posicionamento das bandas de plasmon em colóides. NPs esféricas apresentam bandas de absorção entre 300 e $450 \mathrm{~nm}$; as pentagonais apresentam bandas entre 500 e $600 \mathrm{~nm}$ e as com formato de prisma 
triangular apresentam bandas entre 600 e $750 \mathrm{~nm}$ [36]. Quando o tamanho da NP aumenta, ocorre o deslocamento da banda de plasmon para comprimentos de onda maiores conforme explicado anteriormente.

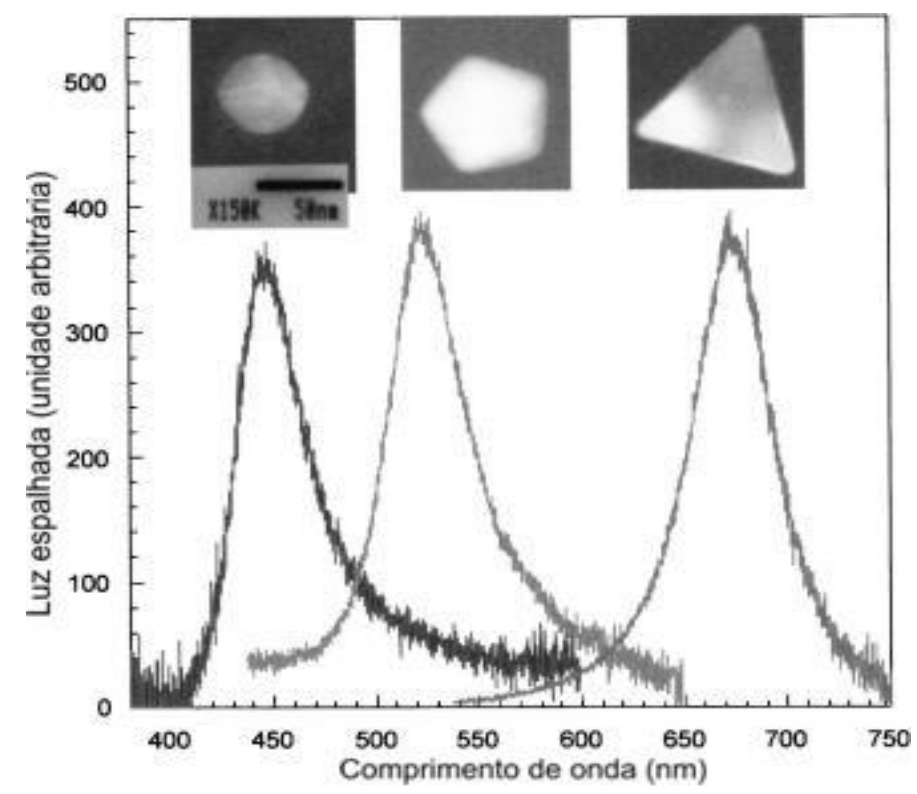

Fig. 13- Interferência da forma das NPs na posição das bandas de absorção dos plasmons superficiais, em colóides com NPs de prata [36].

Plasmons relativos a nanopartículas metálicas podem alterar a luminescência produzida pelos íons de TRs. Os três diferentes tipos de efeitos plasmônicos que podem interferir nas propriedades radiativas e não radiativas de íons de TRs são [34, 37]:

- Aumento do Campo Local - O aumento do campo local em torno dos íons de TR devido à presença das NPs metálicas concentra a densidade de excitação local ao redor dos íons, aumentando a emissão luminescente. NPs facetadas e de tamanho inferior a $5 \mathrm{~nm}$ intensificam o aumento do campo local [34].

- Transferência de energia entre os íons de TRs e as NPs - Esta interação introduz um canal adicional de decaimento não-radiativo, que depende da distância entre o íon e a NP [34].

- $\quad$ Aumento da Taxa Radiativa - Interação entre o íon de terra-rara e uma nanoestrutura metálica que aumenta a taxa radiativa intrínseca do íon de terra-rara. A taxa de decaimento radiativo é descrita pela "Regra de Ouro de Fermi". Portanto, íons mais próximos do que $5 \mathrm{~nm}$ da superfície das NP têm geralmente sua luminescência diminuída [34]. 
Para distâncias compreendidas entre $5 \mathrm{~nm}$ e $20 \mathrm{~nm}$, o aumento da luminescência pode ser favorecido, tanto pelo aumento do campo local, como pelo aumento das taxas radiativas [34].

A amplificação otimizada na presença de nanopartículas metálicas foi o motivo pelo qual foram produzidos no presente trabalho filmes com nanopartículas de $\mathrm{Au}$.

Há vários trabalhos do grupo publicados desde 2005 [2, 12, 13, 37] que demonstram aumento da luminescência dos íons de terras-raras por meio da nucleação de nanopartículas de ouro ou prata em vidros de germanatos e teluretos.

Cabe acrescentar que até o momento foram realizados estudos de nucleação de ouro em filmes de germanato $\left(\mathrm{GeO}_{2}-\mathrm{PbO}\right)$ [12]. Foram feitos também filmes de $\mathrm{GeO}_{2}-\mathrm{PbO}$ com prata [12] e de $\mathrm{TeO}_{2}-\mathrm{ZnO}$ com ouro [38]. Portanto, este trabalho representa o primeiro estudo de nucleação do ouro em filmes finos com composição BWT. 


\section{Materiais e métodos}

\subsection{Produção dos alvos}

Para a produção do alvo BWT foram usados os reagentes $\mathrm{Bi}_{2} \mathrm{O}_{3}, \mathrm{WO}_{3}$ e $\mathrm{TeO}_{2}$ nas concentrações determinadas pela literatura [8].

O procedimento inicial usado para a produção dos alvos é mostrado no fluxograma abaixo (Fig. 14):

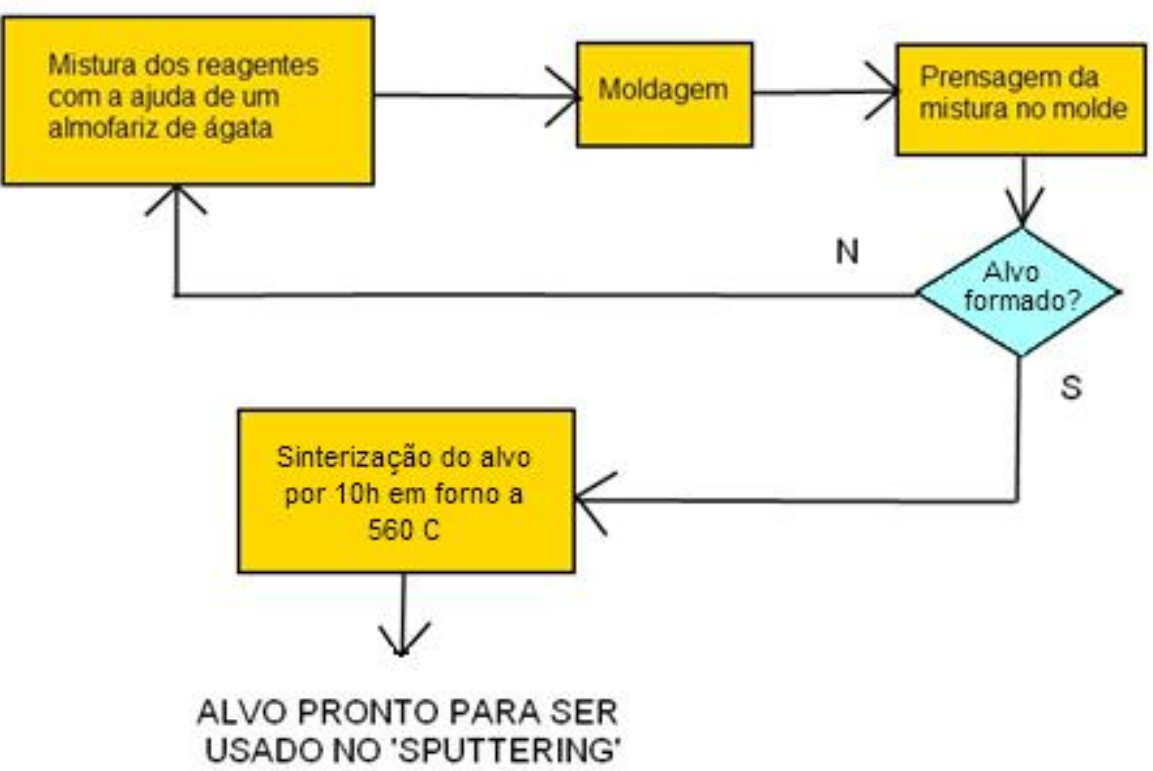

Fig. 14 - Fluxograma da preparação dos alvos cerâmicos

$\mathrm{O}$ alvo cerâmico foi sinterizado a $560^{\circ} \mathrm{C}$ para adquirir a resistência necessária para manter a integridade estrutural durante o sputtering.

A seguir é mostrado um forno usado para a sinterização (Fig. 15): 


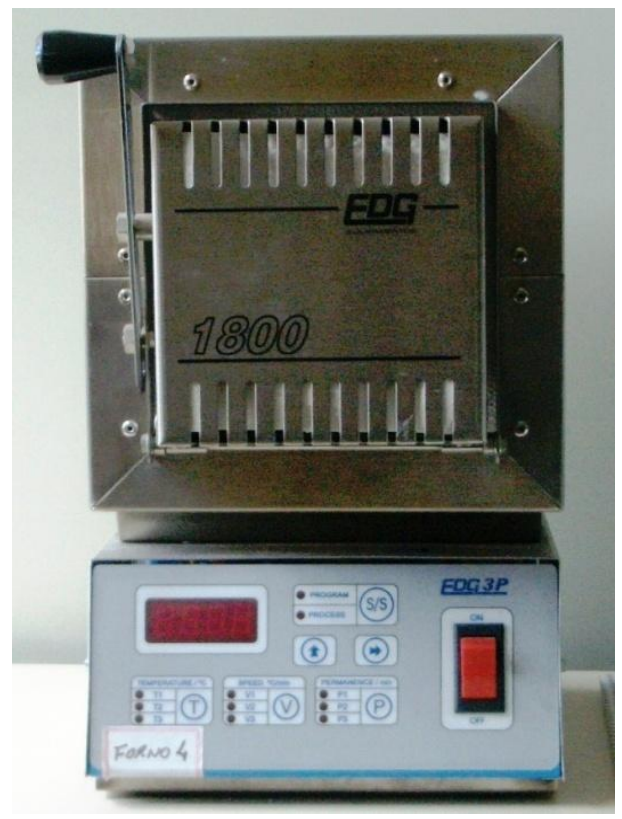

Fig. 15 - Forno usado para sinterização e tratamento térmico dos alvos

O alvo formado deve ser retirado do molde antes de ser submetido à sinterização. A Fig. 16 mostra o aspecto do alvo produzido dessa forma:

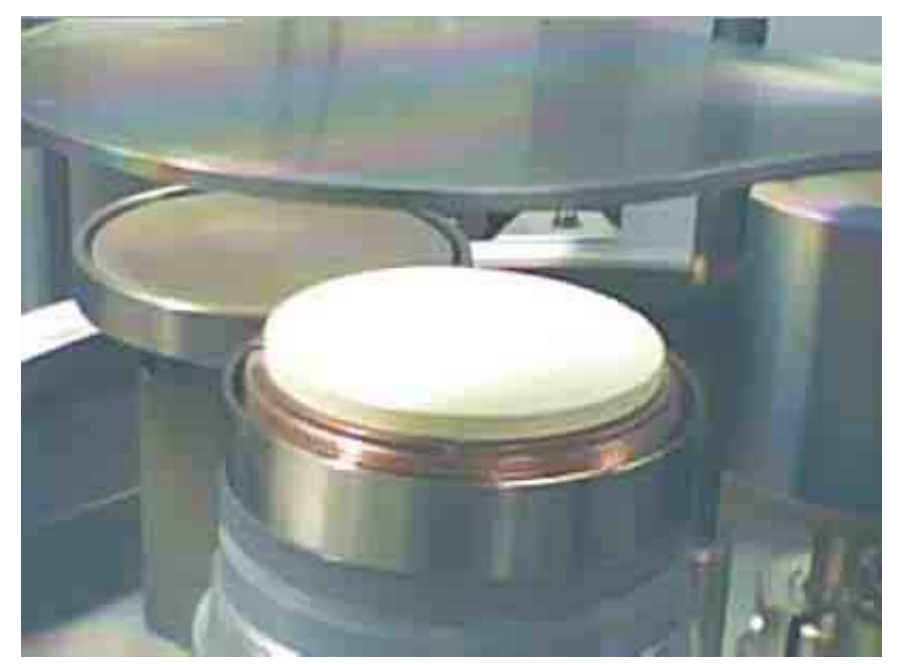

Fig. 16 - Alvo vítreo de BWT utilizado na fabricação de filmes finos

\subsection{Fabricação dos filmes}

Os filmes são depositados em substratos de vidro (para caracterização óptica) e de silício (para medidas de microscopia eletrônica de transmissão e elipsometria, e também para produção de guias de ondas). 
Os substratos de vidro, nos quais serão depositados os filmes de BWT, devem ser previamente limpos antes de serem usados. Para a limpeza das peças de vidro, o procedimento é basicamente uma imersão em álcool etílico ou isopropílico num béquer, para a remoção dos resíduos.

A limpeza dos substratos de vidro pode ser feita no local do sputtering.

A deposição dos filmes por sputtering deve obedecer a vários parâmetros, de acordo com a composição do filme a ser produzido. Os parâmetros usados no processo são:

- pressão de base: a pressão dentro da campânula do aparelho do sputtering sem a introdução dos gases formadores do plasma;

- pressão de operação: a pressão dentro da campânula com a introdução dos gases formadores de plasma;

- potência RF: é a potência de cada fonte RF, para cada alvo; na evaporadora EV-300 presente no LVD, são dois alvos e, portanto, duas fontes RF;

- abertura de shutter: controla o fluxo de partículas arrancadas pelo sputtering na direção do alvo;

- distância do(s) alvo(s) aos substratos: é inversamente proporcional ao sputtering yield $\mathrm{S}$

- rotação: trata-se da rotação da bandeja onde estão fixados os substratos, a fim de permitir a uniformidade dos filmes; normalmente, é utilizada $70 \%$ da velocidade máxima;

- fluxo dos gases formadores de plasma, em sccm (centímetros cúbicos padrão por minuto).

Além disso, é necessário determinar o tempo para o processo, a fim de obter filmes mais ou menos finos. Algumas caracterizações exigem filmes mais espessos, como a microscopia eletrônica de transmissão (MET), que utiliza fragmentos do filme colhidos cuidadosamente após cisalhamento da superfície do filme. 
Estes parâmetros são determinados antes do processo, e podem ser adequados a partir de processos anteriores feitos em filmes germanatos e teluretos com outras composições.

Até agora, foram produzidos filmes BWT com e sem nanopartículas de Au e Si.

O procedimento para o sputtering obedece às seguintes etapas:

\section{Etapas prévias para a deposição:}

a. Pré-programação de alguns parâmetros, como o fluxo de gases no sistema.

b. Ajuste na distância entre o catodo e o anodo, a fim de otimizar a deposição do material nos substratos.

c. Sem contato manual direto (uso de luva), introduzir o alvo na região do catodo.

d. Limpeza prévia dos substratos de vidro com heptano, que remove eventuais resíduos orgânicos.

e. Introdução dos substratos limpos no anodo, com o auxílio da pinça.

f. Abertura da válvula geral.

g. Acionamento da bomba mecânica.

h. Fechamento da câmara, que deve ser pressionada até a formação do vácuo.

i. Aciona-se a bomba turbomolecular quando a pressão interna da câmara atinge $10^{-1}$ Torr

j. Quando a pressão interna do sistema chegar à pressão de base, os gases são liberados pela abertura das válvulas de fluxo.

k. As fontes RF são ligadas e ajustadas.

1. Regulagem da abertura da válvula geral até atingir a pressão de operação.

m. Acionamento do RF, quando atingir a pressão de operação. A potência de RF deve ser ajustada logo no começo da operação. Forma-se o plasma na região do catodo. Os shutters devem, inicialmente, estar fechados, isto é, posicionados a forma a impedir qualquer deposição no alvo. Este procedimento, chamado pré-sputtering, dura cerca de 10 min. e serve para limpeza da superfície dos alvos.

n. Abertura do shutter para o começo da deposição.

\section{Etapas posteriores à deposição:}

o. Fechamento do fluxo dos gases, após o término da operação, e desligamento do RF. 
p. Fechamento da válvula de alto vácuo.

q. Desligamento da bomba turbo-molecular.

r. Abertura da válvula de arejamento para restabelecer a pressão atmosférica dentro da câmara e possibilitar a abertura desta.

S. Retirada dos substratos com os filmes já depositados.

t. Limpeza dos eletrodos.

u. Fechamento da câmara.

v. Abertura da válvula de vácuo para criar uma atmosfera de pré-vácuo (a bomba mecânica ainda está acionada). Isto dificulta a entrada de partículas dentro da campânula enquanto a evaporadora não está em uso.

w. Desligamento da bomba mecânica.

x. Desligamento da chave geral.

Apresentamos a seguir os parâmetros usados na deposição dos diversos filmes, mostrados na tabela 1 abaixo:

Tabela 1 - Parâmetros usados para a deposição dos filmes produzidos

\begin{tabular}{|c|c|c|c|}
\hline Parâmetro & BWT matriz s/O & $B W T$ matriz $c / O_{2}$ & $B W T+A u$ \\
\hline Potência de RF1 (W) & 40 & 40 & 40 (BWT) \\
\hline Potência de RF2 (W) & - & - & $6(\mathrm{Au})$ \\
\hline Fluxo de Ar (sccm) & 18 & 18 & 18 \\
\hline Fluxo de $\mathrm{O}_{2}(\mathrm{sccm})$ & - & 6 & 6 \\
\hline Pressão de base (Torr) & $2,9 \times 10^{-5}$ & $2,9 \times 10^{-5}$ & $5,0 \times 10^{-5}$ \\
\hline $\begin{array}{l}\text { Pressão de operação } \\
\text { (Torr) }\end{array}$ & $5 \times 10^{-3}$ & $5 \times 10^{-3}$ & $5 \times 10^{-3}$ \\
\hline $\begin{array}{l}\text { Distância alvo- } \\
\text { substrato }(\mathrm{cm})\end{array}$ & 15 & 15 & 15 \\
\hline Rotação & $\begin{array}{c}70 \% \text { da rotação } \\
\text { máxima }\end{array}$ & $\begin{array}{c}70 \% \text { da rotação } \\
\text { máxima }\end{array}$ & $\begin{array}{c}70 \% \text { da rotação } \\
\text { máxima }\end{array}$ \\
\hline Tempo (min.) & 120 & 360 & 360 \\
\hline
\end{tabular}

Podemos observar que foram feitos alguns filmes sem fluxo de $\mathrm{O}_{2}$. $\mathrm{O}$ fluxo de $\mathrm{O}_{2}$ pode aumentar a transparência destes filmes e por isso foram feitos processos de deposição com e sem o referido fluxo. 


\subsection{Tratamentos térmicos dos filmes para nucleação}

Os tratamentos térmicos seguem, aproximadamente, os tratamentos feitos para os vidros correspondentes. No caso do BWT produzido no decorrer da iniciação científica com base na literatura [8], a temperatura de tratamento térmico deste vidro foi de $360^{\circ} \mathrm{C}$.

Para haver nucleação das nanopartículas metálicas os filmes foram submetidos a tratamentos térmicos determinados empiricamente. Este procedimento foi usado para os filmes com nanopartículas de Au.

Quando uma das amostras tratadas com substrato de vidro apresentar algum resultado satisfatório, anota-se a duração e a temperatura do tratamento imposto a esta amostra, e o mesmo procedimento será feito para pelo menos uma amostra de filme depositado no silício. Estas amostras são partes de uma lâmina inteira. Normalmente a orientação cristalográfica desta lâmina é $\left[\begin{array}{ll}1 & 0\end{array}\right]$, o que facilita o seccionamento desta para obtenção das amostras.

Outro método utilizado foi a utilização de uma chapa aquecida (hotplate) com um sistema de luz ultravioleta (UV). O feixe de UV incide sobre uma área pequena da amostra, e assim temos uma parte tratada apenas com radiação térmica, e outra, com radiação térmica e UV simultaneamente. As amostras sem nanopartículas só foram submetidas a tratamento térmico por forno elétrico convencional.

A potência da lâmpada usada como fonte de UV é de $30 \mathrm{~W}$.

Antes de colocar a amostra, o feixe de UV deve estar ligado por pelo menos $30 \mathrm{~min}$., pois a lâmpada leva este tempo para estabilizar a emissão.

Por utilizar emissão eletromagnética de alta energia, é obrigatório o uso de óculos e luvas especiais, que minimizam os efeitos do UV sobre a pele e os olhos. Um cilindro oco de aço isola a amostra e o feixe. A temperatura é regulada e controlada por um termistor.

A Fig. 17 mostra o arranjo do sistema UV utilizado juntamente com o hotplate. 


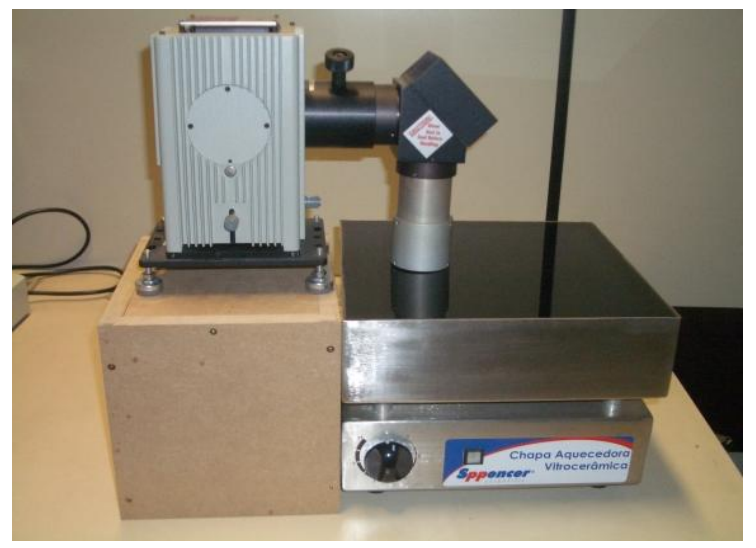

Fig. 17 - Sistema de tratamento com hotplate e UV

\subsection{Processos de fabricação dos guias de onda ópticos}

Para a fabricação dos guias de onda foram utilizados como substratos lâminas de silício tipo P, orientação cristalográfica (100), resistividade de 10 a $20 \Omega . c m$ e 75 mm de diâmetro. As etapas de fabricação são detalhadas a seguir:

\subsubsection{Limpeza das lâminas}

A limpeza das lâminas de silício é realizada para remover traços de impurezas como íons de sódio, metais e particulados que são prejudiciais, pois eles podem se espalhar e se difundir no interior dos filmes depositados. Portanto, trata-se de um requisito essencial para o sucesso na fabricação de dispositivos ópticos e circuitos integrados.

A limpeza química consiste na imersão das lâminas em soluções padronizadas na seguinte sequência [39, 40]:

1. Lavagem em água deionizada (DI) por 5 minutos para remoção de particulados;

2. Imersão em solução de ácido sulfúrico $\left(\mathrm{H}_{2} \mathrm{SO}_{4}\right)+$ peróxido de hidrogênio $\left(\mathrm{H}_{2} \mathrm{O}_{2}\right)$ por 10 minutos, cuja temperatura de reação é de $100^{\circ} \mathrm{C}$ (reação exotérmica). Nesta solução são removidos os compostos orgânicos e promove-se uma oxidação na superfície; 
3. Lavagem em água DI por 5 minutos para neutralizar a solução anterior;

4. Imersão por 10 minutos em solução de hidróxido de amônio $\left(\mathrm{NH}_{4} \mathrm{OH}\right)+$ peróxido de hidrogênio $\left(\mathrm{H}_{2} \mathrm{O}_{2}\right)$ aquecida a $80^{\circ} \mathrm{C}$ em chapa aquecida;

5. Lavagem em água DI por 5 minutos para neutralizar a solução anterior;

6. Imersão por 10 minutos em solução de ácido clorídrico $(\mathrm{HCl})+$ peróxido de hidrogênio $\left(\mathrm{H}_{2} \mathrm{O}_{2}\right)$ aquecida a $80^{\circ} \mathrm{C}$ em chapa aquecida;

7. Lavagem em água DI por 5 minutos para neutralizar a solução anterior;

8. Imersão por alguns segundos em solução de ácido fluorídrico (HF) para a remoção do óxido formado nas etapas 2 a 6 ;

9. Lavagem em água DI por 5 minutos para neutralizar a solução anterior.

Com a remoção do óxido, as lâminas saem completamente secas pois a superfície do Si é hidrofóbica. Ao término dessa etapa, as lâminas são levadas imediatamente ao forno de oxidação, evitando-se a contaminação pela exposição prolongada ao ambiente.

A etapa 2 é conhecida como "Limpeza Piranha". As etapas 4 a 7 são conhecidas como "Limpeza RCA" [39]. A oxidação da superfície é obtida pela ação do $\mathrm{H}_{2} \mathrm{O}_{2}$, enquanto o $\mathrm{NH}_{4} \mathrm{OH}$ remove resíduos orgânicos e o $\mathrm{HCl}$ reage com os íons metálicos.

\subsubsection{Oxidação térmica}

Nesta etapa, a lâmina de silício é exposta a um ambiente oxidante $\left(\mathrm{O}_{2}, \mathrm{H}_{2} \mathrm{O}\right)$ em altas temperaturas, resultando na oxidação do substrato de Si [41], usado como camada de isolação dos guias ópticos, como mostra a Fig. 18. Podemos controlar a espessura do filme de $\mathrm{SiO}_{2}$ formado alterando os parâmetros do processo como a temperatura, a concentração do elemento oxidante ou o tempo de oxidação.

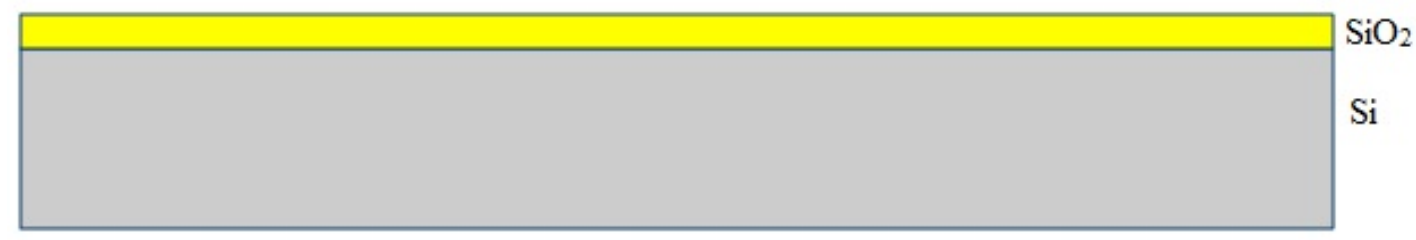

Fig. 18 - Camada de isolação óptica para os guias de onda formada por oxidação térmica 
Foi utilizado um forno convencional da Thermco Systems do LSI, com os parâmetros adotados em trabalhos anteriores [2, 12], mostrados na tabela 2:

Tabela 2 - Parâmetros de oxidação adotados na obtenção do filme $\mathrm{SiO}_{2}$ térmico

\begin{tabular}{c|c}
\hline Parâmetro & Valor \\
\hline Fluxo de $\mathrm{O}_{2}$ & $21 / \mathrm{min}$. \\
Temperatura & $1150^{\circ} \mathrm{C}$ \\
Tempo & $2 \mathrm{~h}$ \\
Espessura final & $1-1,2 \mu \mathrm{m}$ \\
\hline
\end{tabular}

\subsubsection{Deposição do filme BWT para os guias}

Os filmes BWT foram depositados pela técnica de RF "magnetron sputtering”. A Fig. 19 mostra a camada de guiamento BWT depositada sobre a camada de isolação. No processo de sputtering é preciso haver uma alta uniformidade de espessura e uma baixa rugosidade superficial no filme obtido, para possibilitar a implementação de guias ópticos de alta qualidade.

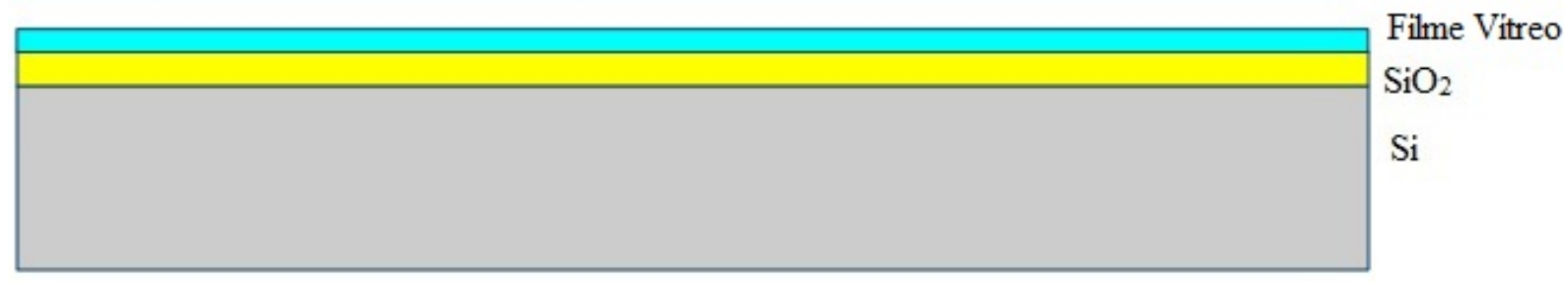

Fig. 19 - Camada de guiamento (filme BWT) depositado por sputtering sobre a camada de isolação $\left(\mathrm{SiO}_{2}\right)$

A tabela 3 apresenta os parâmetros de deposição usados para o filme BWT. Foram produzidos filmes com a inserção de fluxo de oxigênio. Sabe-se que na deposição de filmes de óxidos, o gás $\mathrm{O}_{2}$ é utilizado juntamente com o Ar para compensar o oxigênio perdido durante o sputtering e melhorar a qualidade estequiométrica do filme, conforme experimentos feitos pelo grupo. 
Tabela 3 - Parâmetros usados para a deposição do filme BWT usado para os guias de onda

\begin{tabular}{|c|c|}
\hline Parâmetro & Filme BWT \\
\hline Potência de RF (W) & $40(\mathrm{BWT})$ \\
\hline Fluxo de $\mathrm{Ar}\left(\mathrm{sccm}^{*}\right)$ & 18 \\
\hline Fluxo de $\mathrm{O}_{2}\left(\mathrm{sccm}^{*}\right)$ & 6 \\
\hline Pressão de base (Torr) & $5,0 \times 10^{-5}$ \\
\hline Pressão de operação (Torr) & $5 \times 10^{-3}$ \\
\hline Distância alvo-substrato $(\mathrm{cm})$ & 15 \\
\hline Rotação & $70 \%$ da rotação máxima \\
\hline Tempo (min.) & 577 \\
\hline
\end{tabular}

* sccm - standard cubic centimeter per minute - unidade de fluxo de gás

\subsubsection{Tratamento térmico do filme BWT}

Após a deposição, os filmes BWT produzidos no LVD foram submetidos a tratamentos térmicos em forno elétrico resistivo por $10 \mathrm{~h}$ à temperatura de $360^{\circ} \mathrm{C}$. Após tratamento térmico os filmes apresentaram alta transparência evidenciada no espectro de transmitância apresentado no capítulo 5 (Resultados). O tratamento térmico serve para consolidação dos filmes.

\subsubsection{Fotogravação dos guias ópticos por litografia}

A definição dos guias ópticos de BWT foi realizada por um processo litográfico óptico convencional [42]. A Fig. 20 mostra a deposição e revelação do fotorresiste sobre o filme de guiamento. 


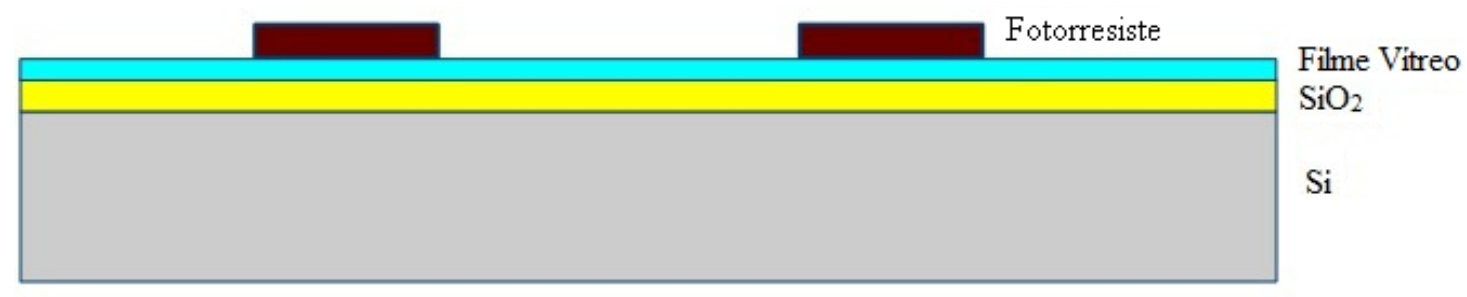

Fig. 20 - Fotogravação dos guias ópticas sobre o filme de guiamento

Nesta etapa o filme de guiamento foi coberto pelos fotorresistes (positivos) AZ5214 e V90, sensíveis à luz ultravioleta. Após a deposição do fotorresiste é feita a cura, chamada de "pré-bake" [41], que serve para evaporar o solvente, aumentando a aderência do fotorresiste no filme. Uma máscara contendo o padrão das linhas é alinhada com a lâmina, para depois iniciar a exposição à luz UV. Esta luz atravessa as partes transparentes da máscara, sensibilizando o fotorresiste e provocando a despolimerização da região exposta. Então, o fotorresiste sensibilizado é revelado, expondo as regiões na lâmina onde será feita a corrosão no óxido.

A lâmina deve estar isenta de partículas na superfície da lâmina e da máscara. A presença dessas partículas causa problemas na revelação do fotorresiste e quando encontrada na máscara pode bloquear a passagem da radiação UV comprometendo a transferência dos padrões geométricos da máscara para a lâmina.

Após a exposição, temos regiões com fotorresiste sensibilizado e não-sensibilizado. Durante o mergulho da amostra em solução reveladora, o filme de fotorresiste sensibilizado é removido, transferindo o padrão da máscara para o fotorresiste.

O processo litográfico foi realizado usando o resiste V90, seguindo os seguintes passos:

1) Secagem com álcool isopropílico por $20 \mathrm{~s}$ a $3500 \mathrm{rpm}$ no spinner;

2) Aplicação do promotor de aderência hexametildissilazana (HMDS) por $20 \mathrm{~s}$ a 3500 rpm no spinner;

3) Aplicação do fotorresiste por $20 \mathrm{~s} \mathrm{a} 3500 \mathrm{rpm}$ no spinner;

4) Cura de $90 \mathrm{~s}$ na temperatura de $105^{\circ} \mathrm{C}$ em uma chapa aquecida;

5) Exposição à luz ultravioleta por $15 \mathrm{~s}$; 
6) Revelação do fotorresiste por cerca de $40 \mathrm{~s}$ em solução com 3 partes de revelador MIF 312 e 1 parte de água D.I.;

7) Cura de 5 minutos a $130^{\circ} \mathrm{C}$ em uma chapa aquecida.

A máscara litográfica utilizada neste processo é composta de uma placa de quartzo $(10 \mathrm{x}$ $10 \mathrm{~cm}$ ) com um filme de cromo, onde os dispositivos foram previamente transferidos por uma exposição por feixe de elétrons. O esquema utilizado é mostrado na Fig. 21. Esta máscara possui vários conjuntos de linhas com larguras de 1 a $10 \mu \mathrm{m}$, separados por linhas de $85 \mu \mathrm{m}$ de largura.

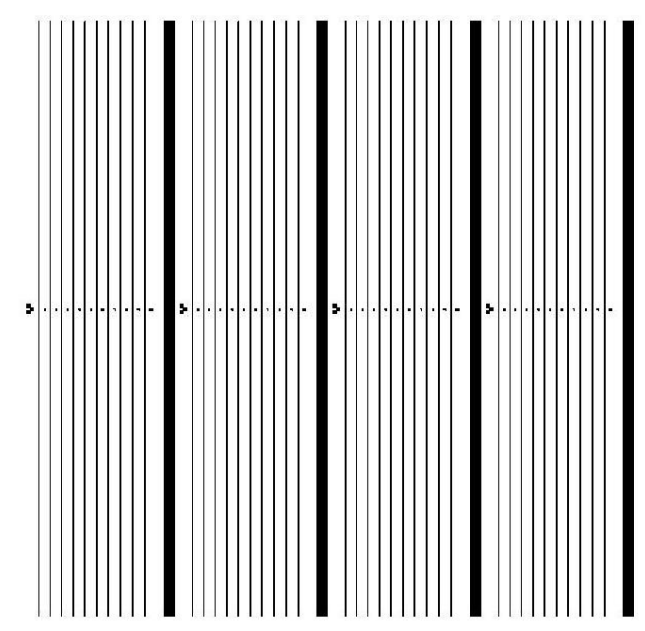

Fig. 21 - Layout da máscara usada para a fabricação de guias de onda BWT [31]

Os parâmetros do processo de litografia (deposição do resiste, exposição e revelação) foram ajustados para se obter uma resolução de $1 \mu \mathrm{m}$ nas estruturas contidas no padrão de guias de onda. Os padrões de linhas com larguras de 1 e $2 \mu \mathrm{m}$ servem para verificar a qualidade do processo de revelação do resiste após a exposição. Os guias de onda são definidos pelos padrões de linhas entre 3 e $10 \mu \mathrm{m}$ e utilizados na caracterização dos modos guiados e nas medidas de atenuação.

\subsubsection{Corrosão dos filmes de BWT}

Os guias "rib" foram obtidos por uma corrosão parcial dos filmes vítreos (h_core) nas regiões fora do guia, como indicado na Fig. 22. 


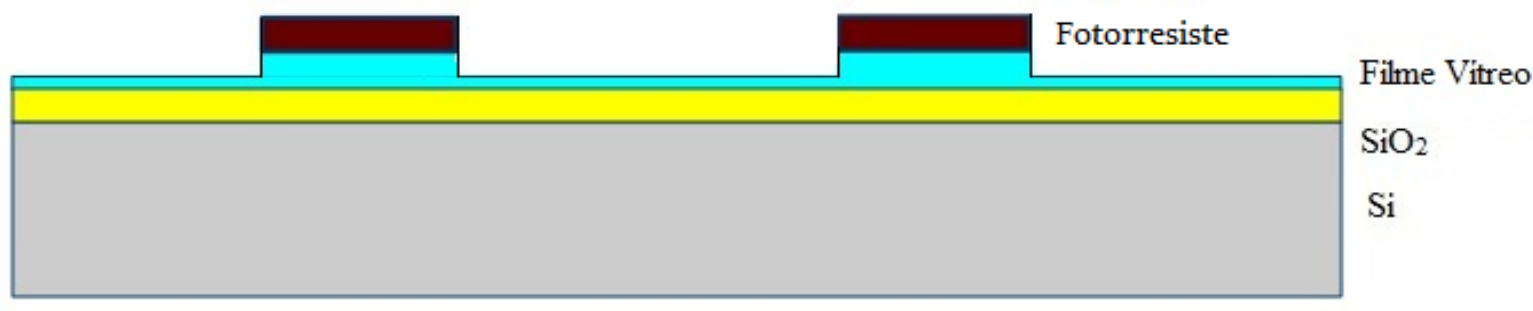

Fig. 22 - Corrosão e definição dos guias "rib" no filme de guiamento

Os trabalhos anteriores do grupo avaliaram empiricamente os processos de corrosão para os diversos guias de onda produzidos. Em nosso trabalho foi utilizada a corrosão seca (por plasma), seguindo os resultados do trabalho de doutorado anterior do grupo [2].

A corrosão seca envolve o uso de gases na forma de plasma. Quando o filme entre em contato com o plasma, a parte exposta do filme é removida por uma combinação de processos físicos e químicos [44].

Ao colocarmos a superfície de um filme em contato com o plasma, as espécies energéticas interagem com esta superfície e reagem quimicamente com o material a ser corroído. Se os produtos de reação são voláteis, ocorrerá remoção do material da superfície, ou seja, uma corrosão seca [45, 46].

O equipamento de corrosão utilizado neste trabalho é um reator de placas paralelas trabalhando no modo RIE ("Reactive Ion Etching") com eletrodos assimétricos do Laboratório de Sistemas Integráveis da Escola Politécnica de São Paulo (LSI-EPUSP). As amostras são posicionadas no eletrodo inferior, o qual está ligado à fonte. Um esquema desse reator é mostrado na Fig. 23. Na região entre os eletrodos mostra-se a região de plasma. Entre o eletrodo inferior e o plasma temos a região de bainha. 


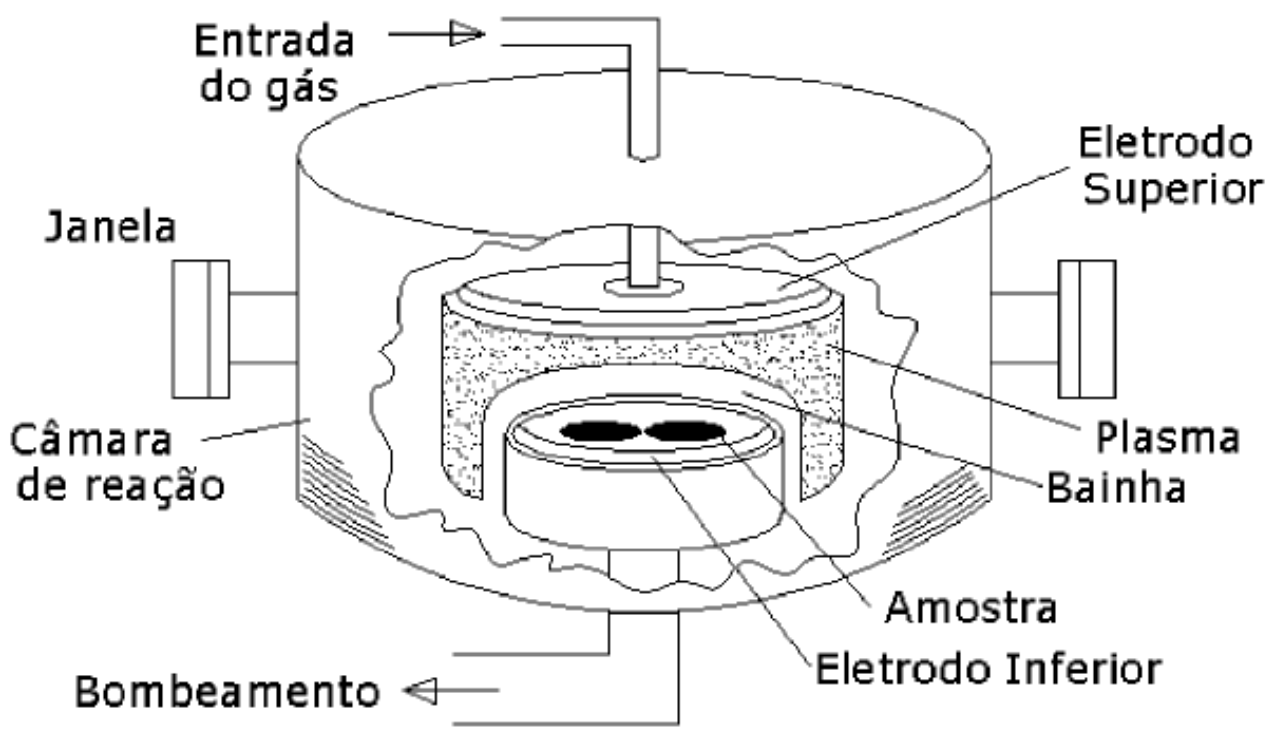

Fig. 23 - Aspecto do plasma e da bainha no reator RIE [12]

A formação do plasma nesses reatores ocorre da seguinte maneira: aplica-se um sinal $\mathrm{RF}$, geralmente de $13,56 \mathrm{MHz}$, na mistura gasosa entre os eletrodos. Nos primeiros poucos ciclos, os elétrons (partículas leves) seguem as variações do campo elétrico em direção aos eletrodos e parede da câmara mais rapidamente do que os íons (de maior massa). Com isso, os eletrodos ficam carregados negativamente e o plasma, positivamente. Um campo elétrico DC é formado entre o plasma e os eletrodos, determinando o potencial de bainha. Devido a este campo, os íons positivos que se encontram na periferia do plasma são atraídos para a superfície da amostra, colidindo e reagindo com o filme exposto. [47, 48, 49].

Na Fig. 24 é apresentada uma foto do reator utilizado. A câmara de processo é fabricada com aço inoxidável com $310 \mathrm{~mm}$ de diâmetro interno e $85 \mathrm{~mm}$ de espaçamento entre os eletrodos. O gás de processo é admitido via tampa superior, a qual possui um distribuidor em forma de "crivo", de $150 \mathrm{~mm}$ de diâmetro, com furos de $0,8 \mathrm{~mm}$ de diâmetro e espaçamento entre eles de $10 \mathrm{~mm}$.

O sistema de bombeamento é composto por uma bomba mecânica para o "pré-vácuo" e uma bomba "roots" para formação do alto vácuo. A descarga é excitada por um conjunto gerador de RF (modelo RFX-600) e malha acopladora (modelo ATX-600). Este conjunto pode fornecer descarga de até $200 \mathrm{~W}$ de potência de RF com frequiência de 13,56 MHz. 


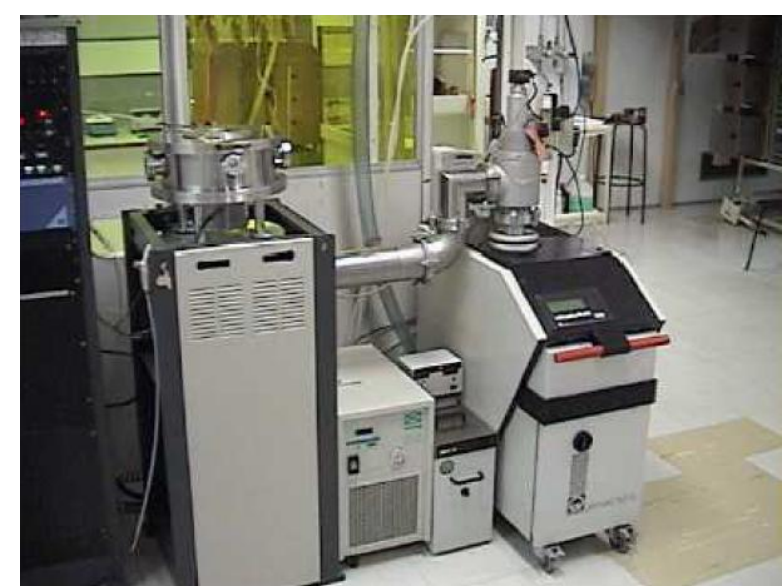

Fig. 24 - Aparelho reator usado na corrosão RIE

Para o filme BWT foi usado o $\mathrm{SF}_{6}$, com parâmetros mostrados na tabela 4. O uso do $\mathrm{SF}_{6}$ teve por base os experimentos empíricos para a corrosão dos filmes anteriores feitos pelo grupo [2]. A natureza diferente do BWT em relação aos filmes anteriores motivou o emprego de uma potência RF maior, de $50 \mathrm{~W}$ [2] para $100 \mathrm{~W}$.

Tabela 4 - Parâmetros de corrosão usados para os guias de onda BWT

\begin{tabular}{|c|c|c|c|c|}
\hline Mistura & Fluxo (sccm) & Pressãa (mTorr) & Potência RF (W) & Tempo (min) \\
\hline $\mathrm{SF}_{6}$ & 15 & 100 & 100 & 5 \\
\hline $\mathrm{SF}_{6}$ & 25 & 100 & 100 & 5 \\
\hline
\end{tabular}

\subsubsection{Remoção do fotorresiste}

A remoção do fotorresiste foi feita por meio da solução Microstripper 2001 ("Positive Photo Resist Stripper"). As amostras foram mergulhadas por 1 h. nesta solução e depois enxaguadas com água DI por 5 min.

Este procedimento foi usado com sucesso em trabalhos anteriores do grupo [2] e foi adotado no presente trabalho. A qualidade final é analisada por meio da microscopia eletrônica de varredura conforme será visto.

O resultado após a remoção do fotorresiste é mostrado na Fig. 25: 


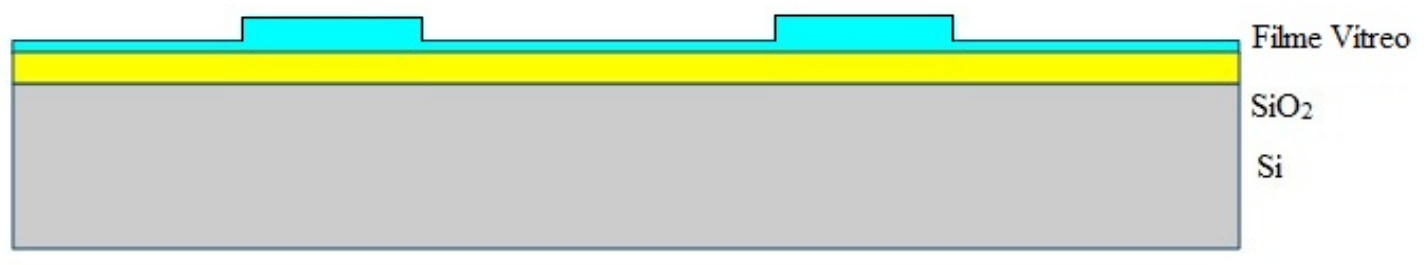

Fig. 25 - Resultado da limpeza e remoção do fotorresiste para os guias BWT

\subsection{Técnicas de caracterização dos filmes e dos guias de onda}

\subsubsection{Perfilometria e elipsometria}

A perfilometria é um dos métodos de medição da espessura de filmes finos.

Essas medidas são feitas por um aparelho chamado perfilômetro, disponível no LSI/EPUSP. O perfilômetro mecânico é basicamente um mecanismo que controla uma agulha móvel, cujo percurso envolve o degrau formado pelo limite do filme. Ela começa a mover-se, com pressão suficiente para garantir a confiabilidade da leitura sem danificar o filme nem o substrato, num ponto do filme. Ela passa pelo degrau e chega ao substrato não coberto, onde ela é levantada pelo mecanismo de leitura, terminando a medição. O caminho inverso também pode ser feito, quando a agulha começa a medição no substrato e termina no filme.

As irregularidades da superfície sentidas pela agulha são convertidas em sinais elétricos, traduzidos por um gráfico de altura em função do deslocamento. A região do degrau pode ser vista como uma brusca descida (quando o percurso começa no filme e termina no substrato) ou como uma subida (quando o percurso é no sentido inverso). Cursores ajudam a fazer as medições do degrau, fornecendo a espessura do filme. Também é possível avaliar as rugosidades do filme por este método.

A elipsometria é um procedimento óptico bastante eficiente na medição de espessura de filmes com um mínimo de transparência, por meio da utilização de luz polarizada para medir diferenças de fase entre a luz que foi apenas refletida e a luz que sofreu refração na camada de depósito e reflexão na superfície opaca do substrato, para novamente refratar para o meio. 
Esses dois feixes de luz são interceptados por leitores ópticos. Tanto os emissores quanto os receptores ópticos fazem parte de aparelhos chamados elipsômetros.

O elipsômetro também é capaz de avaliar o índice de refração (n) do material.

Geralmente são utilizados os espectros visíveis e de infravermelho (IR). Filmes vítreos são transparentes a essas duas faixas de frequiência, e seu índice de transparência é muito variável. Logo, há tanto a reflexão direta - característica comum na totalidade dos vidros produzidos - quanto a refração.

O elipsômetro do LSI-USP está regulado para substratos em silício, por ser este o material usado na micro e nanoeletrônica, até então. Por isso as amostras submetidas à elipsometria são filmes depositados em silício.

Está localizado na mesma sala do perfilômetro, no LSI/EPUSP. Portanto, pode ser usado em conjunto com este aparelho, que fornece a espessura. Logo, nas medidas do elipsômetro, pode-se tomar como parâmetro o valor medido no perfilômetro. A espessura, no elipsômetro, é identificada como TU. Então, basta utilizar um feixe no comprimento de onda (geralmente $\lambda=632,8 \mathrm{~nm}$, ou laser de $\mathrm{He}-\mathrm{Ne}$ ) para se obter o valor de $\mathrm{n}$, identificado como NU.

Quando o perfilômetro não é utilizado, adotam-se dois comprimentos de onda (o outro é um feixe no infravermelho próximo: $\lambda=806 \mathrm{~nm}$ ), que segue critérios compatíveis com o material a ser analisado, para comparação de resultados.

O elipsômetro faz a leitura da amostra em vários pontos, que são numerados. Se os resultados de cada ponto forem semelhantes, é um bom indicativo da conformidade do filme, isto é, ausência de gradientes de espessura. Caso contrário, o filme é não conforme e, portanto, não apresenta qualidade compatível com as aplicações em dispositivos fotônicos.

\subsubsection{Microscopia eletrônica de varredura (MEV)}

A microscopia eletrônica de varredura (MEV) é uma técnica de obtenção de imagens de figuras microscópicas. 
Por meio de um canhão eletrônico, um feixe de elétrons é conduzido de uma fonte emissora (eletrodo negativo) para a amostra. Um filamento capilar de tungstênio gera o feixe. Este material, além de relativamente abundante na natureza, é excelente fornecedor de elétrons, devido à configuração eletrônica do seu subnível mais energético (5d), preenchido com 4 elétrons. Antes de atingir a amostra, o feixe deve passar por lentes condensadoras, a fim de concentrar o feixe em uma área menor e evitar a dispersão na superfície do objeto. A lente objetiva serve para ajuste do foco. $\mathrm{O}$ interior do canhão eletrônico é mantido em vácuo, para evitar a interferência de partículas ou moléculas durante a trajetória do feixe eletrônico.

O feixe incide sobre o objeto e os elétrons retroespalhados são então captados por um detector de elétrons. Neste detector, os sinais são convertidos em pontos da imagem. Também há a geração de elétrons secundários, arrancados da eletrosfera dos átomos pelos elementos do feixe. Estes elétrons secundários também são captados pelo detector e sua taxa de geração varia conforme o tipo de material.

No trabalho, foi feito uma microscopia eletrônica de varredura dos guias de onda produzidas.

Abaixo, na fig. 26 [50], há um esquema de um microscópio eletrônico de varredura:

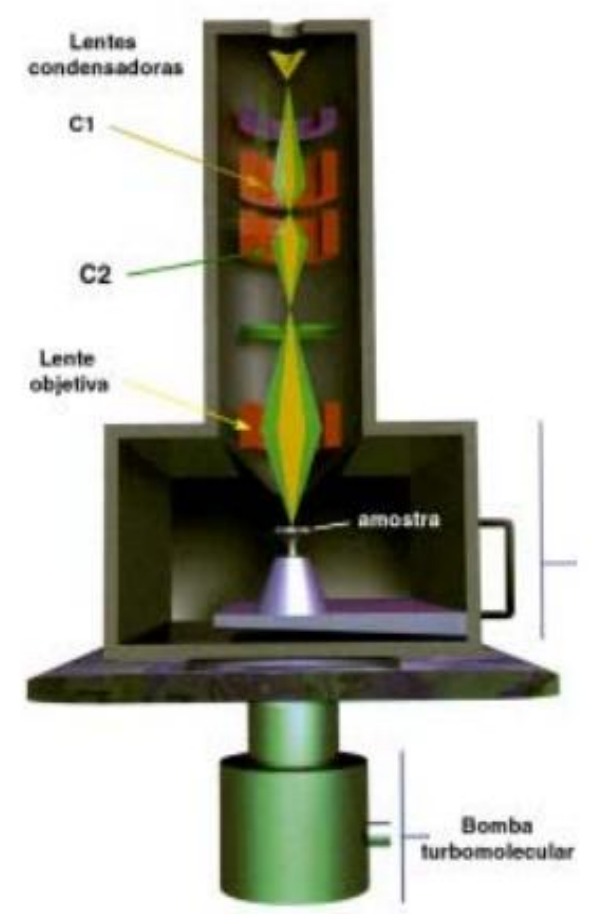

Fig. 26 - Esquema de um microscópio eletrônico de varredura. C1 e C2 são as lentes condensadoras. A bomba turbomolecular é responsável pela geração do vácuo dentro do canhão eletrônico [38] 
As análises de MEV foram feitas no equipamento Nova NanoSEM da Fei Company no Laboratório de Sistemas Integráveis (LSI) da Escola Politécnica da Universidade de São Paulo (EPUSP). O substrato utilizado foi Si e as tensões aceleradoras sempre da ordem de 20 $\mathrm{kV}$. Foi utilizada uma inclinação de $45^{\circ}$ no porta-amostra a fim de se observar o perfil lateral dos guias fabricados.

Essa técnica foi usada para avaliar a qualidade dos guias de onda produzidos por litografia e corrosão.

\subsubsection{Microscopia eletrônica de transmissão (MET)}

A técnica de microscopia eletrônica de transmissão (MET) serve para visualizar objetos muito pequenos, com dimensões da ordem de nanômetros. Foi usado para determinar o tamanho e a forma das nanopartículas dos filmes.

Consiste em utilizar um feixe fino de elétrons e um sistema de lentes chamadas de condensadoras, que direcionam o feixe na direção da amostra. $\mathrm{Na}$ amostra, o feixe sofre difração, em estruturas mono ou policristalinas. Os elétrons difratados passam para um conjunto de lentes chamadas projetivas, que ampliam a imagem do nanocristal, projetada numa chapa fotográfica. A Fig. 27 mostra o esquema básico do microscópio eletrônico por transmissão.

A amostra é um objeto sólido, em cuja superfície está pequena quantidade do filme fino depositado. Para a preparação da amostra foi necessário raspar o filme de um substrato (de preferência silício). Esta medida foi feita em equipamento do IFUSP. 


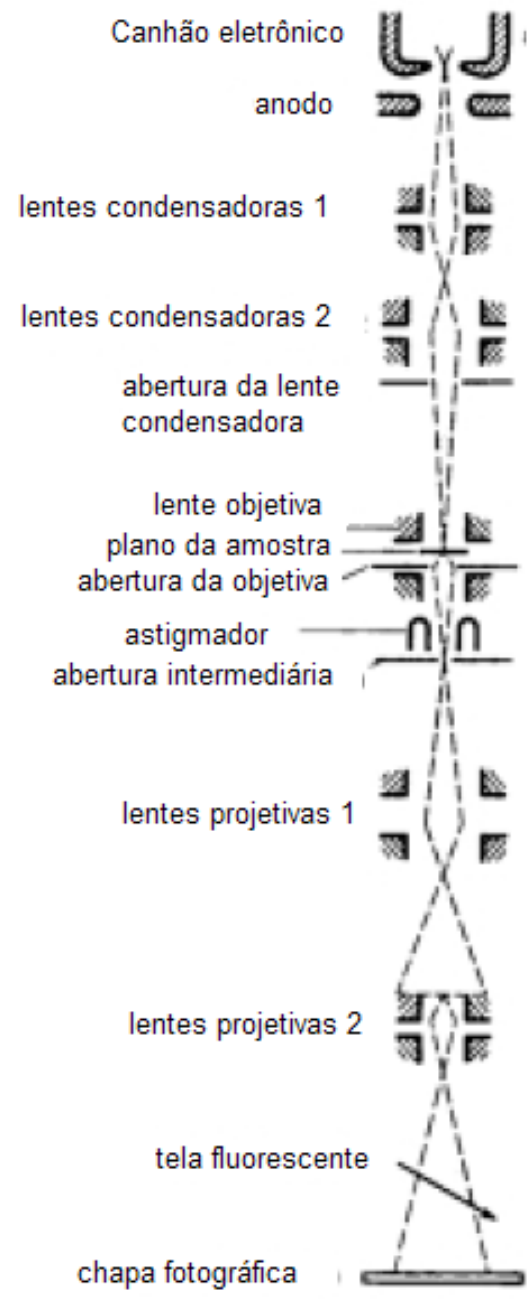

Fig. 27 - Esquema de um microscópio eletrônico de transmissão [51]

\subsubsection{Espectrometria de fluorescência de raios-X por energia dispersiva (EDX)}

Os filmes finos foram analisados pelo aparelho EDX disponível no IPEN-SP. O EDX é uma técnica de caracterização usada para a análise da estequiometria de uma amostra.

Seu princípio de funcionamento utiliza bombardeamento da amostra por um feixe de raios-X.

Cada elemento químico responde de forma particular à ação dos raios-X, devido à quantidade de elétrons e sua distribuição nos diversos níveis (K, L, M, N, ...) e subníveis (s, p, d, f) de energia. Elétrons livres bombardeados na amostra interagem com os elétrons de cada átomo presente, gerando elétrons secundários e raios-X, frutos do deslocamento dos elétrons 
de um subnível mais energético para o nível K (o mais baixo). Por conta disso, elementos mais pesados, que possuem mais subníveis de energia, são mais fáceis de serem detectados por este método. Os raios-X produzidos são coletados por um detector, e interpretados por conversão da energia radiativa em sinais elétricos. O gráfico gerado é uma sucessão de picos correspondentes a cada elemento químico, embora a altura desses picos não corresponda, necessariamente, à sua proporção em massa, pois utilizou-se o procedimento chamado QuanFP. As porcentagens de cada material são calculadas segundo modelos previamente programados no software e fornecidas por meio de uma lista.

\subsubsection{Espectrometria de transmissão e absorção óptica no UV-VIS}

Foi utilizado um espectrofotômetro para avaliar a absorbância e a transmitância dos filmes em um substrato transparente - vidro de sílica - na faixa correspondente entre o ultravioleta próximo e o infravermelho próximo, passando pelo espectro visível (luz). A transmissão e a absorção foram feitas pelo espectrofotômetro do Laboratório de Tecnologia em Materiais Fotônicos e Optoeletrônicos da FATEC-SP.

No gráfico obtido pelo espectrofotômetro, é possível detectar a presença de nanopartículas devido às bandas de absorção do plasmon; também é possível verificar a incorporação dos íons de terras-raras por meio das bandas de absorção associadas às transições eletrônicas.

Tanto a absorção quanto a transmissão óptica foram feitas no espectrofotômetro Ocean Optics da FATEC-SP adquirido com recursos da Rede Nanofoton do CNPq.

\subsubsection{Difração de raios-X (XRD)}

A difração de raios-X (XRD) é uma técnica não-destrutiva que avalia a estrutura de um material. É baseada na lei de Bragg [52], dada pela equação 4.1.: 


\section{$\mathbf{n} \lambda=2 \mathbf{d} \operatorname{sen} \theta(4.1$.}

onde

$\mathrm{n}=$ número correspondente a uma harmônica do comprimento de onda $(\lambda)$ do raio $\mathrm{X}$

$\mathrm{d}=$ distância interplanar

$\theta=$ ângulo do feixe.

A análise de difração é feita num difratômetro, que gera raios-X que incidem na amostra com um ângulo que varia ao longo do tempo. Os raios difratados são detectados e convertidos em um sinal elétrico, que gera o gráfico no programa do computador. O gráfico pode ser visualizado enquanto é desenhado.

Pode-se avaliar a cristalinidade do material pelos picos encontrados. Caso não haja picos significativos, o material pode ser considerado amorfo.

Foi usado um programa chamado PANalytical X'pert HighScore, para avaliação dos materiais correspondentes aos picos do gráfico. O programa fornece a composição e a estrutura cristalina do material.

Para as medições de DRX, foi utilizado equipamento localizado no Laboratório de Materiais da Fatec-SP.

\subsubsection{Caracterização óptica dos guias}

Na caracterização óptica dos guias, avalia-se a capacidade de transmissão de certo feixe de laser no interior da camada de guiamento, e também a possibilidade de espalhamento e perdas por refração, que podem atrapalhar a transmissão do feixe.

Foi utilizada a técnica de vista superior, com o uso de uma fibra óptica para o acoplamento do feixe de $\mathrm{He}-\mathrm{Ne}(\lambda=632,8 \mathrm{~nm})$ e duas câmaras CCD: uma para verificar o feixe durante o guiamento e a outra para detecção do feixe após o guiamento, conforme a fig. 28. Esta técnica foi usada em trabalhos anteriores [31, 53]. 


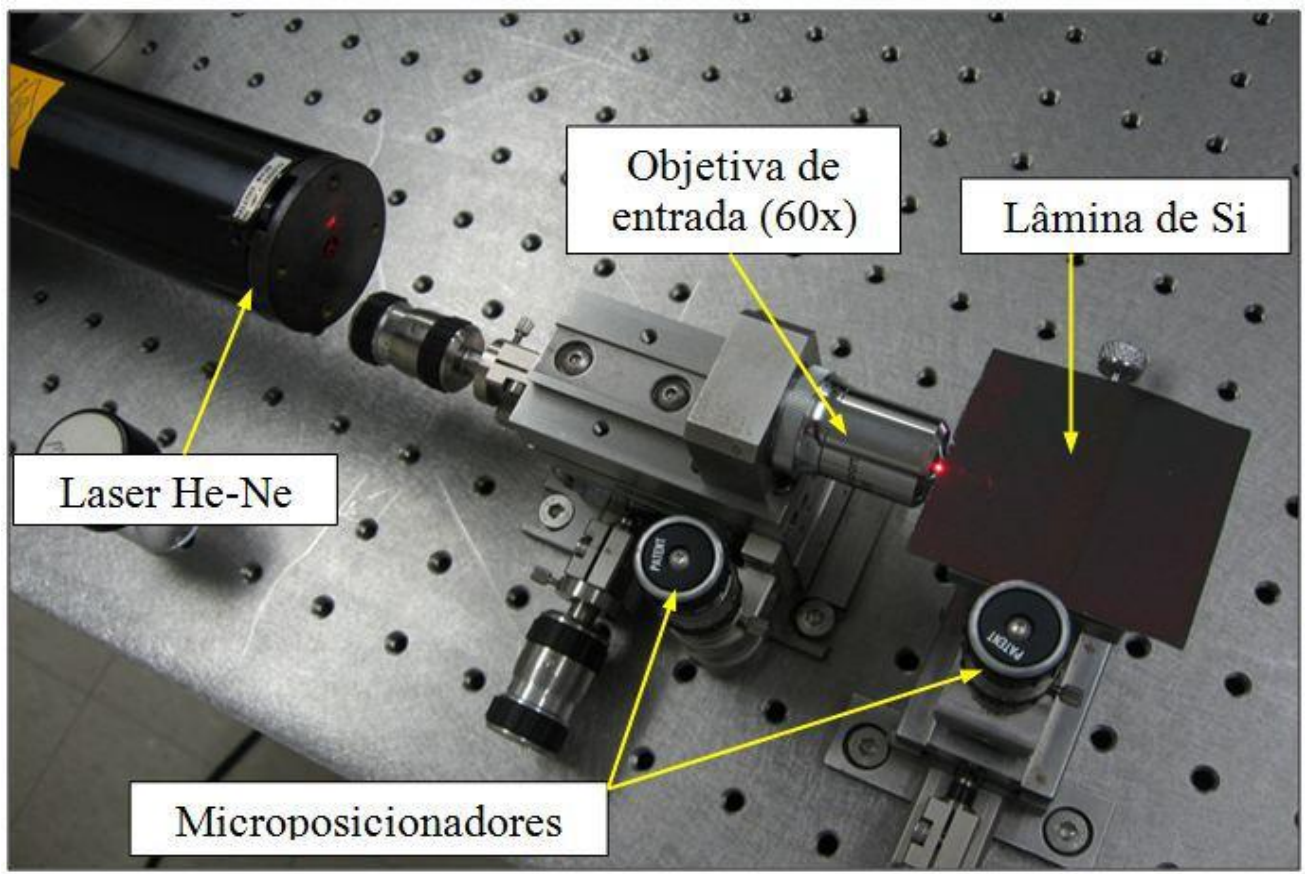

Fig. 28 - Montagem experimental empregada para o acoplamento do laser e medidas de atenuação óptica [53]

Com o auxílio da câmara CCD e de um programa de tratamento de imagens que possibilita medir a variação luminosa no guia de onda, é possível avaliar o dist"rib"uted loss, ou seja, a perda por propagação $\alpha$ (Eq. 4.2.), dada por [22]:

$$
\alpha=-10 \frac{\log \frac{P_{2}}{P_{1}}}{Z_{2}-Z_{1}} \text { (Eq. 4.2.) }
$$

Onde $\mathrm{P}_{1}$ e $\mathrm{P}_{2}$ são as intensidades medidas em dois pontos $\mathrm{Z}_{1}$ e $\mathrm{Z}_{2}$ correspondentes.

O uso da fibra ótica é recomendável para introdução de feixes de laser em guias com menor largura $(\leq 4 \mu \mathrm{m})$. Neste caso, os guias estão próximas do limite da resolução obtida pela litografia óptica, no LSI-EPUSP, que é de $1 \mu \mathrm{m}$.

Os guias ópticos são do tipo "rib" e apresentam largura de 3 a $10 \mu \mathrm{m}$ de acordo com a máscara usada na litografia. Abaixo, na tabela 5, temos a descrição das dimensões dos guias de ondas medidos, de acordo com o esquema da fig. 29: 


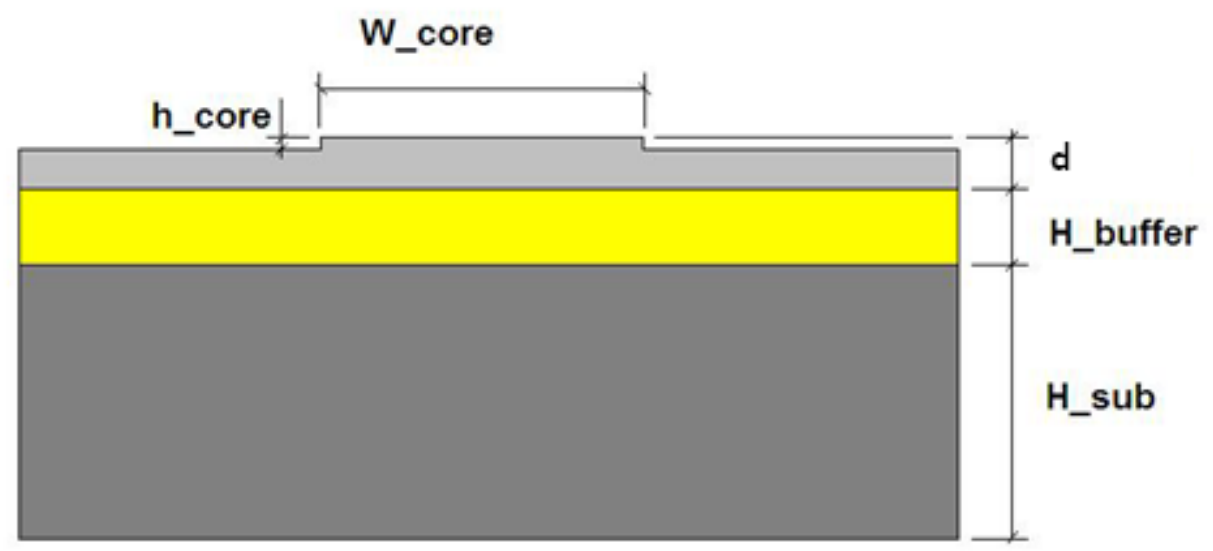

Fig. 29 - Perfil estrutural utilizado na caracterização dos guias de onda [2, 31]

Tabela 5 - Descrição das dimensões dos guias de onda BWT tipo "rib" medidos. A camada de cobertura (H_clad) considerada foi o ar

\begin{tabular}{|c|c|c|}
\hline Parâmetros & Guias de onda BWT & Guias de onda BWT \\
\hline Fluxo nominal de $\mathrm{SF}_{6}$ & $15 \mathrm{sccm}$ & $25 \mathrm{sccm}$ \\
\hline $\begin{array}{c}\text { Espessura da camada de } \\
\text { isolação (H_buffer) }\end{array}$ & $1 \mu \mathrm{m}$ & $1 \mu \mathrm{m}$ \\
\hline $\begin{array}{c}\text { Espessura da camada de } \\
\text { guiamento }(d)\end{array}$ & $311 \mathrm{~nm}$ & $311 \mathrm{~nm}$ \\
\hline Largura (W_core) & $3 \mu \mathrm{m} \mathrm{a} 10 \mu \mathrm{m}$ & $3 \mu \mathrm{m} \mathrm{a} 10 \mu \mathrm{m}$ \\
\hline Corrosão parcial (h_core) & $63 \mathrm{~nm}$ & $380 \mu \mathrm{m}$ \\
\hline Espessura do substrato & $380 \mu \mathrm{m}$ & \\
(H_sub) & & \\
\hline
\end{tabular}

Nota-se que o valor de ' $h$ _core', correspondente ao que foi corroído da camada de guiamento, depende do fluxo de $\mathrm{SF}_{6}$ utilizado na produção dos guias.

Utilizando estes valores, é possível realizar uma simulação dos modos de propagação em polarização TE dentro dos guias, e classificá-los como guias do tipo multímodo ou monomodo. O programa utilizado é o Selene 3.2.02, da BBV Software [27], que simula o guiamento de um feixe de luz. Neste programa, é preciso determinar todos os parâmetros constantes da tabela 5, com exceção do fluxo do gás utilizado na corrosão do filme, que influencia diretamente nas dimensões do h_core. Foram simulados os guiamentos a $\lambda=632,8$ nm e na região do infravermelho (1050 e $1530 \mathrm{~nm})$. 
Por meio do programa Selene 3.2.02 simulamos os modos de propagação em polarização TE para os guias do tipo "rib", supondo um feixe de entrada tipo gaussiano $\left(1 / \mathrm{e}^{2}\right)$ com largura de $4,75 \mu \mathrm{m}$, que é equivalente a uma fibra óptica monomodo de $4 \mu \mathrm{m}$ de diâmetro interno $[54,55]$, e comprimento de onda $(\lambda)$ de $632,8 \mathrm{~nm}$. O modo de propagação TE foi escolhido devido à facilidade na interpretação do sinal de saída quando os guias tipo "rib" forem analisados experimentalmente pelas medidas de atenuação no guiamento.

A espessura da camada de isolação do substrato utilizada foi fixada em $1 \mu \mathrm{m}$, pois proporciona a menor atenuação por "leakage", conforme os resultados obtidos na simulação dos guias planares apresentados no item anterior. A largura do guia (W_core) foi variada em 3, 5 e $10 \mu \mathrm{m}$. A estrutura utilizada na simulação do guia tipo "rib" está representada na Fig. 30. O filme de cobertura (Clad), nesta figura, apresenta índice de refração igual a 1, para ficar de acordo com o perfil dos guias produzidos.

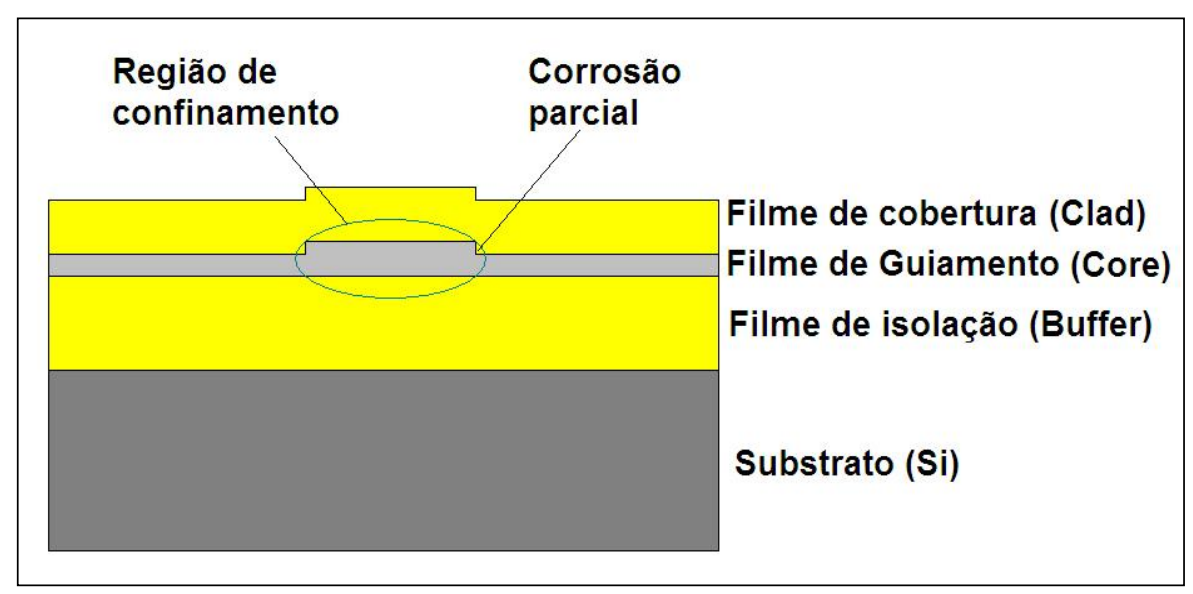

Fig. 30 - Desenho esquemático do guia de onda tipo "rib” usado na simulação [31]. 


\section{Resultados e discussões}

\subsection{Medidas de transmissão e absorção óptica}

\subsubsection{Matriz BWT}

Seguem os resultados das medidas de absorção e transmissão do filme BWT sem nanopartículas, produzido com e sem $\mathrm{O}_{2}$ (fig. 31 a 35):

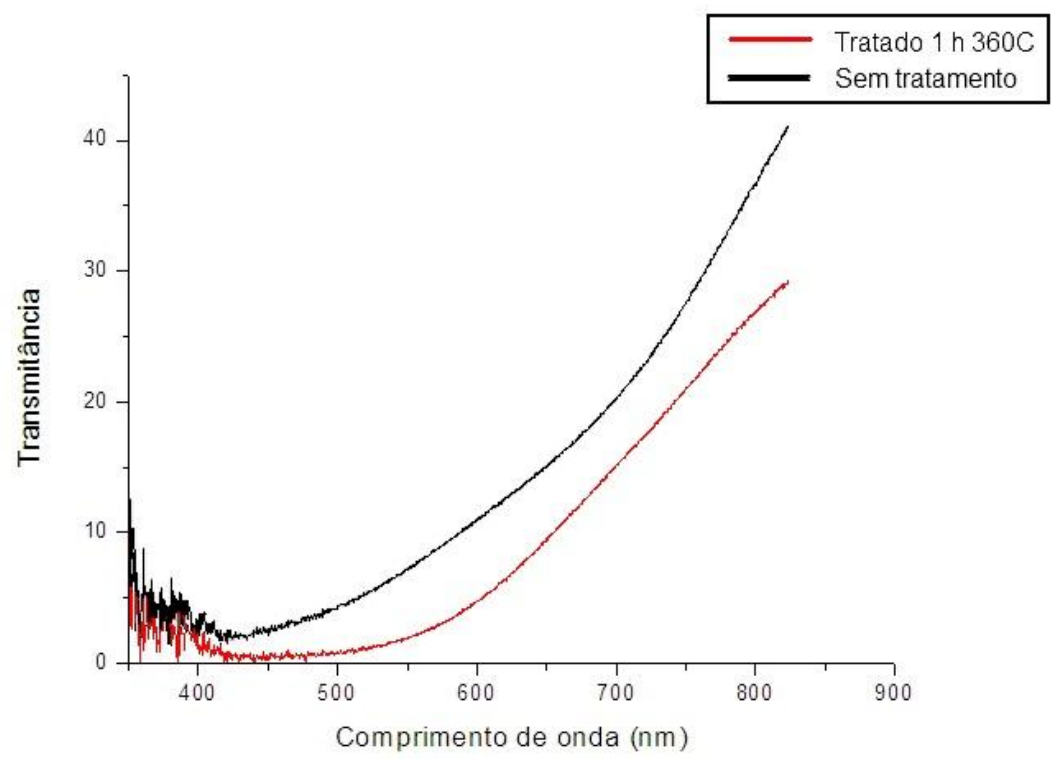

Fig. 31 - Transmitância de amostras BWT fabricadas sem oxigênio

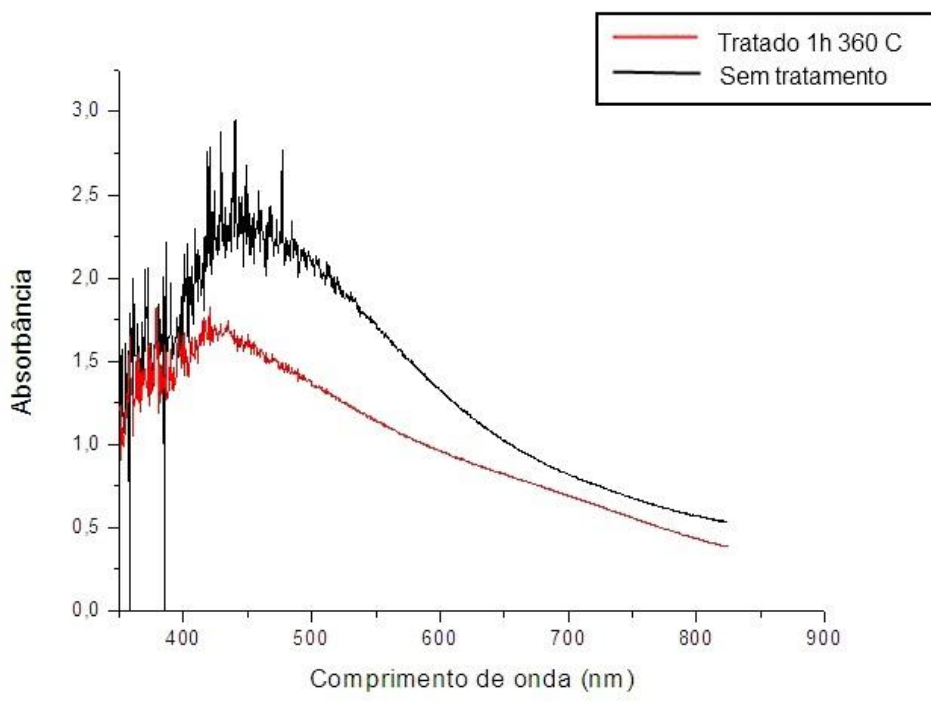

Fig. 32 - Absorbância de amostras BWT fabricadas sem oxigênio 


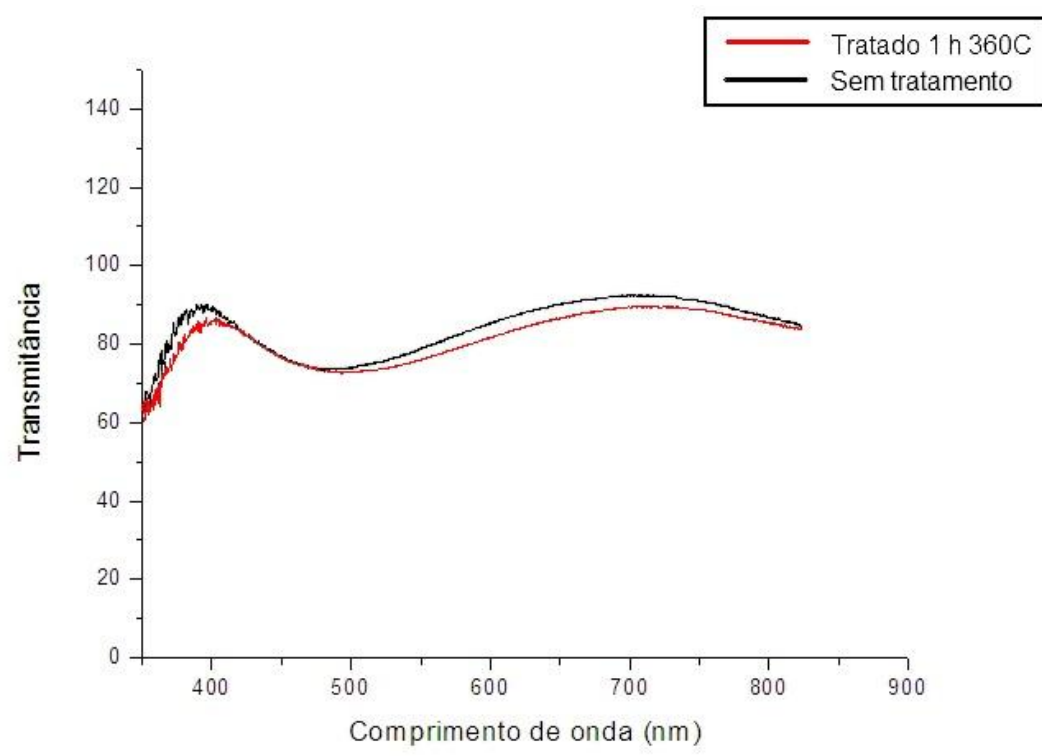

Fig. 33 - Transmitância de amostras BWT fabricadas com oxigênio

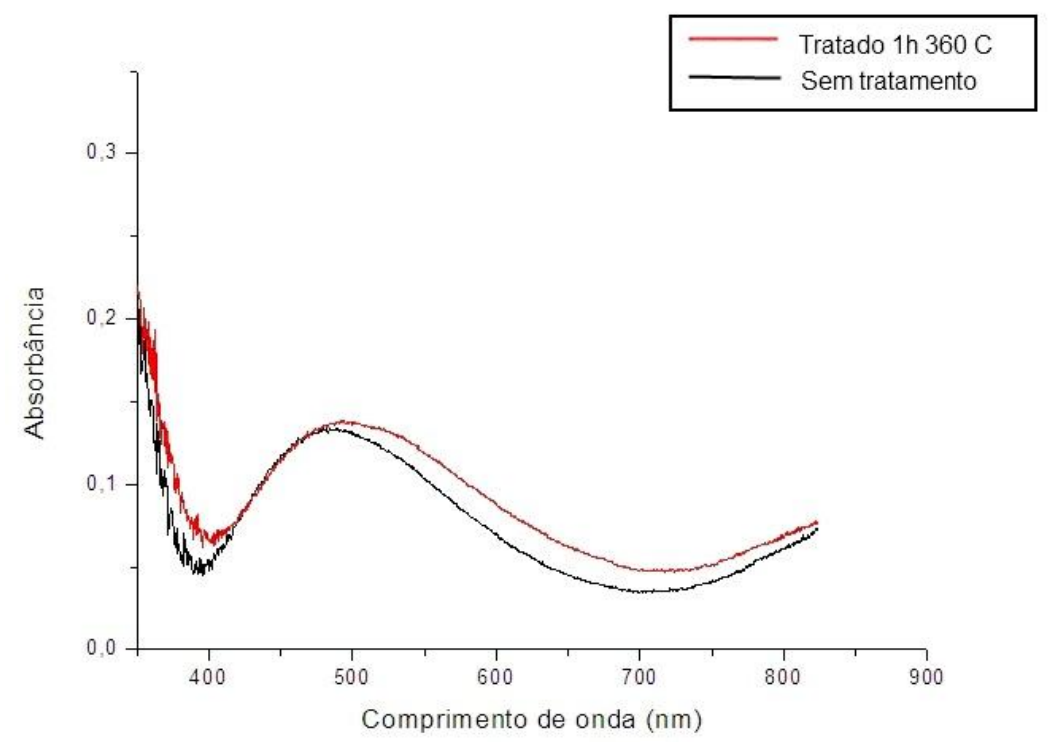

Fig. 34 - Absorbância de amostras BWT fabricadas com oxigênio

Os resultados anteriores mostram que, para a matriz BWT, a presença ou ausência de tratamento térmico não altera o espectro. Entretanto, as maiores transmissões e, portanto, as menores absorções ocorrem para os filmes produzidos com fluxo de $\mathrm{O}_{2}$. Isto pode ser facilmente verificado na fig. 35 abaixo: 


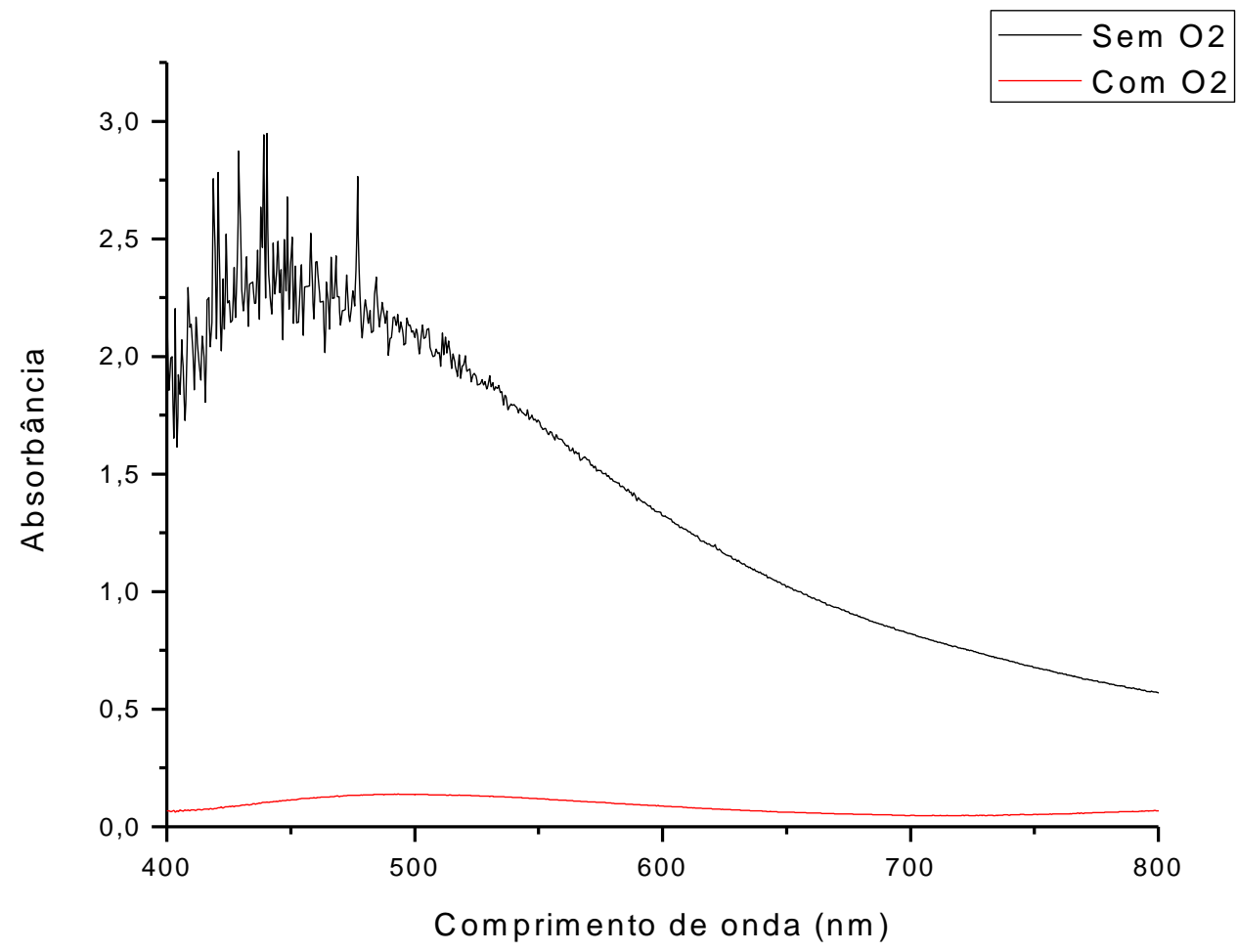

Fig. 35 - Comparação das absorbâncias de amostras BWT tratadas com oxigênio (vermelho) e sem oxigênio (preto). Ambas as amostras foram tratadas por $1 \mathrm{~h}$.

\subsubsection{BWT com nanopartículas de ouro}

Apresentamos a seguir (Fig. 36) os resultados para o filme BWT com nanopartículas de $\mathrm{Au}$, produzido com $\mathrm{O}_{2}$, submetido a tratamento térmico por $2 \mathrm{~h}$ a $20 \mathrm{~h}$, e a tratamento térmico por $2 \mathrm{~h}$ a $20 \mathrm{~h}$ em exposição simultânea ao UV. O tratamento térmico foi fornecido por uma chapa aquecida, denominada hotplate.

Devido aos melhores resultados do BWT produzido com $\mathrm{O}_{2}$, o co-sputtering com $\mathrm{Au}$ foi realizado também na presença do gás, juntamente com o argônio. 


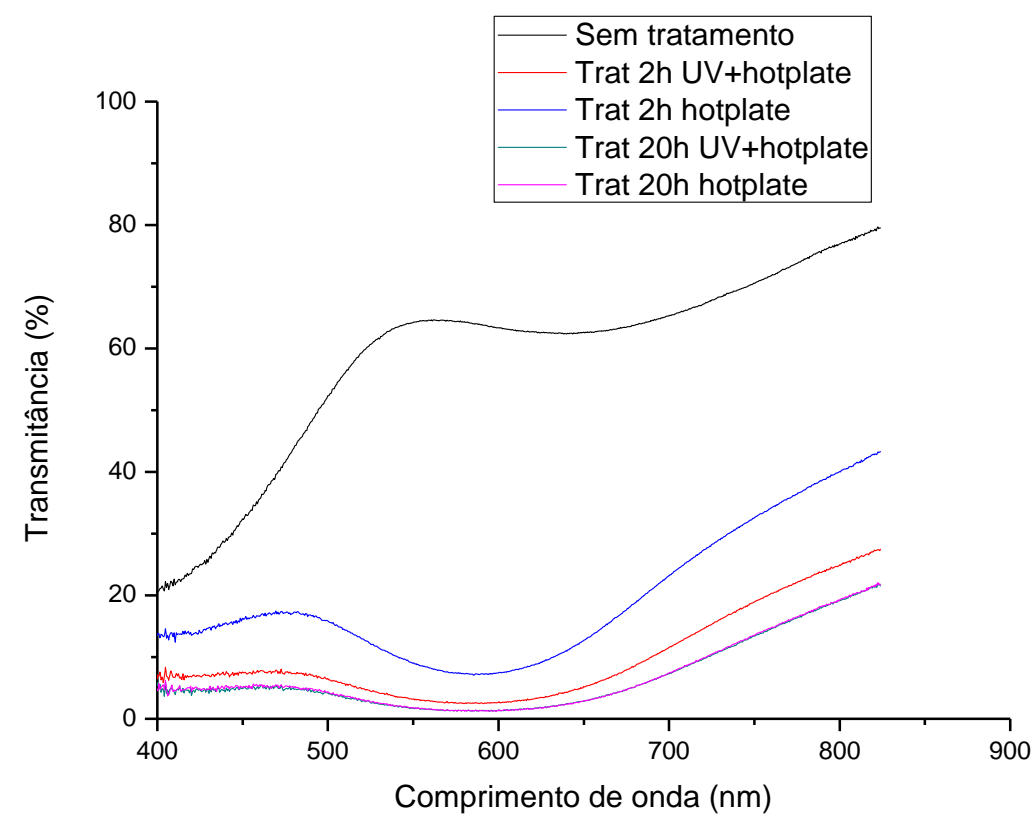

Fig. 36 - Transmitância do BWT com Au sem tratamento, tratado apenas no hotplate a $340^{\circ} \mathrm{C}$ e tratado com hotplate e UV a $340^{\circ} \mathrm{C}$ simultaneamente

Nota-se que o filme mais transparente é aquele que não foi submetido a tratamento. Isto pode ser explicado pela nucleação, que cresce com o aumento do tratamento. Por esse motivo as bandas de absorção do plasmon do ouro situado em $600 \mathrm{~nm}$ crescem com o aumento do tratamento, como pode ser visto na Fig. 37 a seguir.

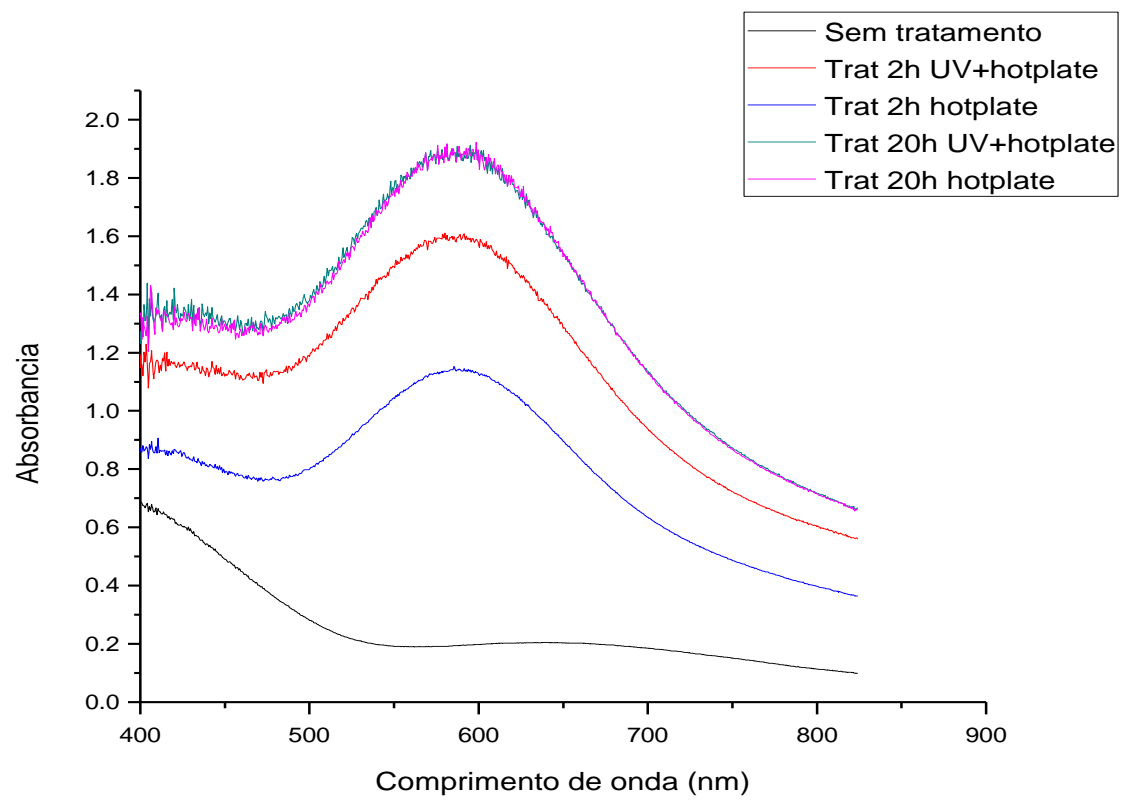

Fig. 37 - Absorção óptica das amostras de BWT sem tratamento, tratadas com hotplate a $340^{\circ} \mathrm{C}$ e tratadas com chapa aquecida (hotplate) a $340^{\circ} \mathrm{C}$ e UV simultaneamente 
Os resultados do tratamento com UV são notáveis para pequenos períodos de tratamento térmico; para períodos mais longos, como 20h, não há diferença significativa. O plasmon do $\mathrm{Au}$ em $600 \mathrm{~nm}$ pode ser notado nos gráficos, principalmente nas curvas que representam maior tratamento térmico.

Pelo gráfico mostrado na Fig. 37 acima, pode-se notar que a ação simultânea do UV e do aquecimento é bastante expressiva quando ocorrem tratamentos térmicos de curta duração. As diferenças nos resultados dos tratamentos térmicos com $2 \mathrm{~h}$ de duração devem-se aos efeitos mais rápidos do UV em relação ao calor, cuja propagação se faz por difusão. Quando se emprega UV, existe aquecimento mais rápido das moléculas irradiadas. Isto pode ser notado comparando-se os resultados do tratamento por $2 \mathrm{~h}$ com UV e chapa aquecida simultaneamente com os do tratamento pelo mesmo período utilizando-se apenas a chapa. A maior nucleação do Au ocorre para tratamento térmico de $20 \mathrm{~h}$ com ou sem exposição simultânea de UV.

\subsection{Perfilometria e elipsometria}

Foram medidas as espessuras dos filmes BWT por meio do perfilômetro e seus respectivos índices de refração, medidos pelo elipsômetro.

Os resultados podem ser vistos na tabela 6 abaixo:

Tabela 6 - Filme de BWT matriz produzida com $\mathrm{O}_{2}$ tratado $(1 \mathrm{~h})$

$\begin{array}{cc}\mathbf{n} & \begin{array}{c}\text { Espessu } \\ (\mathbf{\AA})\end{array} \\ 2,12 & 1101 \\ 2,15 & 1062 \\ 2,12 & 1085\end{array}$

Espessura média: $(1083 \pm 20) \AA$

Índice de refração: $2,13 \pm 0,02$

Tempo de processo: $360 \mathrm{~min}$.

Taxa de deposição média: $(3,00 \pm 0,05) \AA / m i n$. 


\subsection{Espectrometria de Fluorescência de Raios-X}

A tabela 7 abaixo mostra os resultados da estequiometria, em porcentagem de massa, do EDX para os filmes finos de BWT produzidos:

Tabela 7 - Porcentagem em massa dos elementos obtidos pelo EDX. O valor teórico é dado como referência.

\begin{tabular}{ccccc}
\hline Amostra & $\begin{array}{c}\text { Te } \\
(\boldsymbol{\%})\end{array}$ & $\begin{array}{c}\text { W } \\
(\boldsymbol{\%})\end{array}$ & $\begin{array}{c}\text { Bi } \\
(\mathbf{\%})\end{array}$ & $\begin{array}{c}\text { Metallic } \\
(\mathbf{\%})\end{array}$ \\
\hline $\begin{array}{c}\text { BWT teórico } \\
\text { (alvo) }\end{array}$ & 53,2 & 21,9 & 24,9 & - \\
\hline $\begin{array}{c}\text { BWT (feito com } \\
\text { Ar) }\end{array}$ & 44,2 & 22,9 & 32,9 & - \\
$\begin{array}{c}\text { BWT/Au (feito } \\
\left.\text { com Ar }+\mathrm{O}_{2}\right)\end{array}$ & 87,9 & 1,8 & 6,1 & 4,2
\end{tabular}

Fatores como o sputtering yield e a presença de outros gases afetam consideravelmente a estequiometria, durante o processo. O sputtering yield considerando um plasma de Ar, sem qualquer outro gás, é dado na tabela 8:

Tabela 8 - Sputter yield dos elementos para plasma de Ar [56, 57]

\begin{tabular}{cc}
\hline Element & Sputter yield (atoms/ion) \\
\hline $\mathrm{Te}$ & 4,67 \\
$\mathrm{Bi}$ & 2,67 \\
$\mathrm{Au}$ & 1,70 \\
$\mathrm{~W}$ & 0,66 \\
\hline
\end{tabular}

A presença de oxigênio na deposição pode alterar o valor do sputter yield.

Os resultados de EDX mostraram influência do sputtering yield. A taxa de deposição dos diversos elementos, em plasma de Ar, varia bastante, devido ao tamanho do átomo a ser arrancado, isto é, quanto maior o átomo, mais difícil a sua remoção e, portanto, menor o sputtering yield. Os átomos de $\mathrm{Bi}$ e $\mathrm{W}$, cujos raios e massas atômicos são maiores do que os de Te, são mais difíceis de arrancar. 


\subsection{Difração de raios- $X$}

A difração de raios-X mostra-nos resultados que nos permitem analisar a presença ou não de cristalização nos filmes.

Pode-se determinar a natureza do cristal formado, por meio do programa PanAnytical X'Pert Highscore.

No gráfico da matriz BWT produzida apenas com argônio (Fig. 38), houve cristalização dos componentes deste elemento, como pode ser visto a seguir.

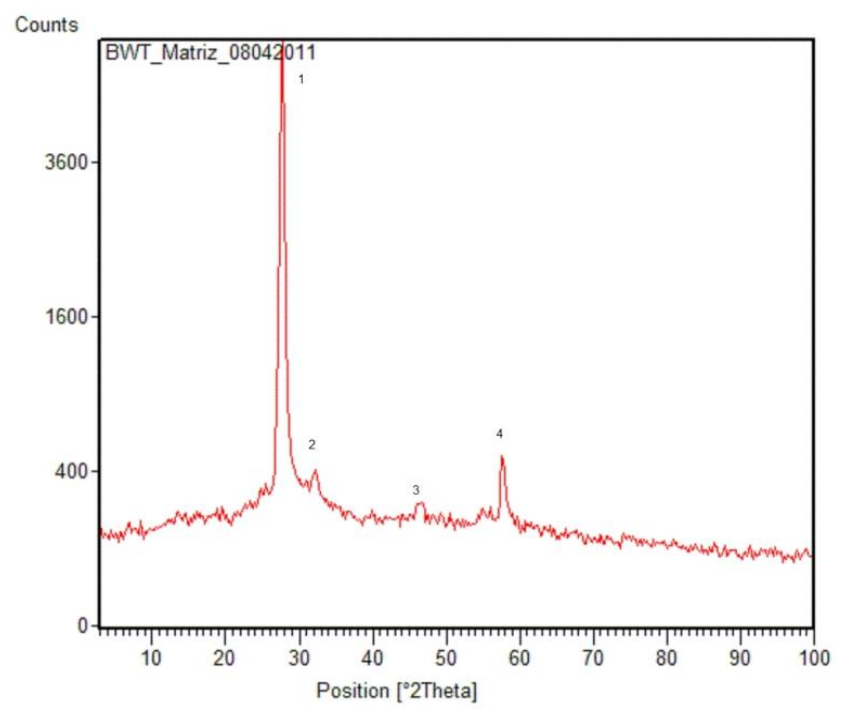

Fig. 38 - Difração referente à amostra de BWT matriz feita apenas com atmosfera de argônio e tratada por 10h a $360 \mathrm{C}$.

Os picos foram extraídos do programa e reproduzidos na tabela 9 abaixo:

Tabela 9 - Picos encontrados na difração do filme de BWT

\begin{tabular}{|c|c|c|c|}
\hline Número do pico & $2 \theta$ (graus) & Cristal e estrutura & Ficha de referência \\
\hline 1 & 27,7 & $\begin{array}{c}\mathrm{Bi}_{2} \mathrm{~W}_{3} \mathrm{Te}_{2} \mathrm{O}_{16} \\
\text { monoclínico }\end{array}$ & $\begin{array}{c}00-052-0053 \text { [58] } \\
01-086-1545[58]\end{array}$ \\
\hline 2 & 32,2 & $2 \mathrm{Bi}_{2} \mathrm{O}_{3}-\mathrm{TeO}_{2}$ & $00-024-0157[59]$ \\
\hline 3 & 46,4 & $\mathrm{Bi}_{0,833} \mathrm{Te}_{0,167}{ }^{\circ} 1,584$ & $00-036-1301[60]$ \\
\hline 4 & 57,6 & $\begin{array}{c}\text { Oxido de telúrio e } \\
\text { bismuto } \\
\left(\mathrm{Bi}_{0,969} \mathrm{Te}_{0,031}{ }^{\circ} 1,584\right. \\
\text { tetragonal }\end{array}$ & $00-037-1174[60]$ \\
& & \multicolumn{2}{|c}{} \\
\hline
\end{tabular}


Os resultados acima indicam tendência de cristalização dos elementos da matriz.

As fichas de referências são dados fornecidos pelo programa PanAnytical X'Pert Highscore. Nelas constam informações como a estrutura e a composição dos cristais [58, 59, 60].

Por outro lado, os resultados da difratometria para os filmes BWT produzidos com $\mathrm{O}_{2}$ não mostraram cristalização. O programa PanAnytical X'Pert não indicou os picos de cristalização durante a análise.

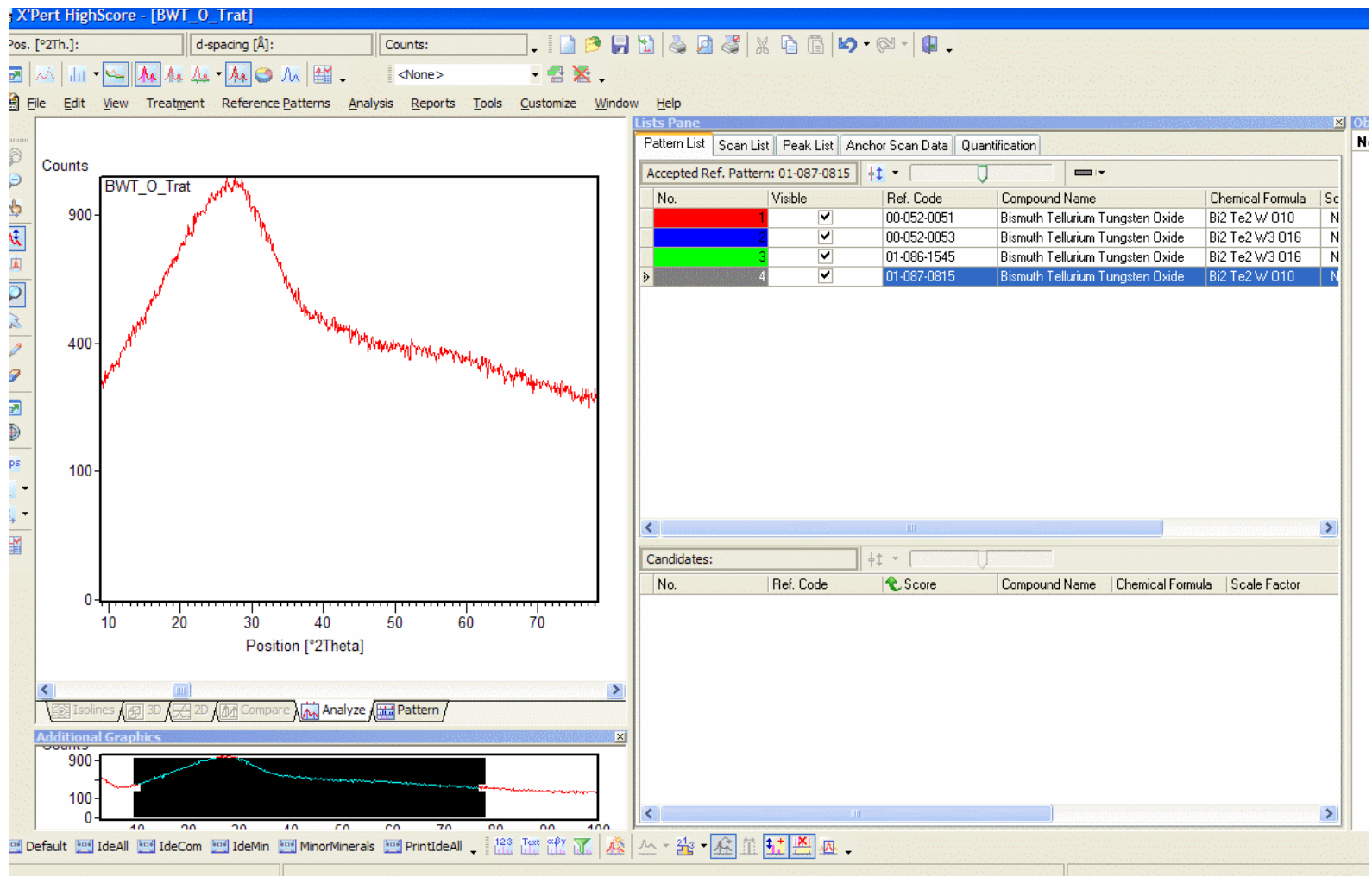

Fig. 39 - Análise da difração de uma amostra BWT produzida com $\mathrm{O}_{2}$ e tratada por $1 \mathrm{~h}$, feita pelo programa PanAlytical.

No gráfico do BWT com ouro (Fig. 40), foram encontrados cristais apenas do Au, segundo as referências contidas no referido programa [61, 62]. A amostra foi produzida com $\mathrm{O}_{2}$, como no caso anterior. Da mesma forma, não se verificou cristalização da matriz. 


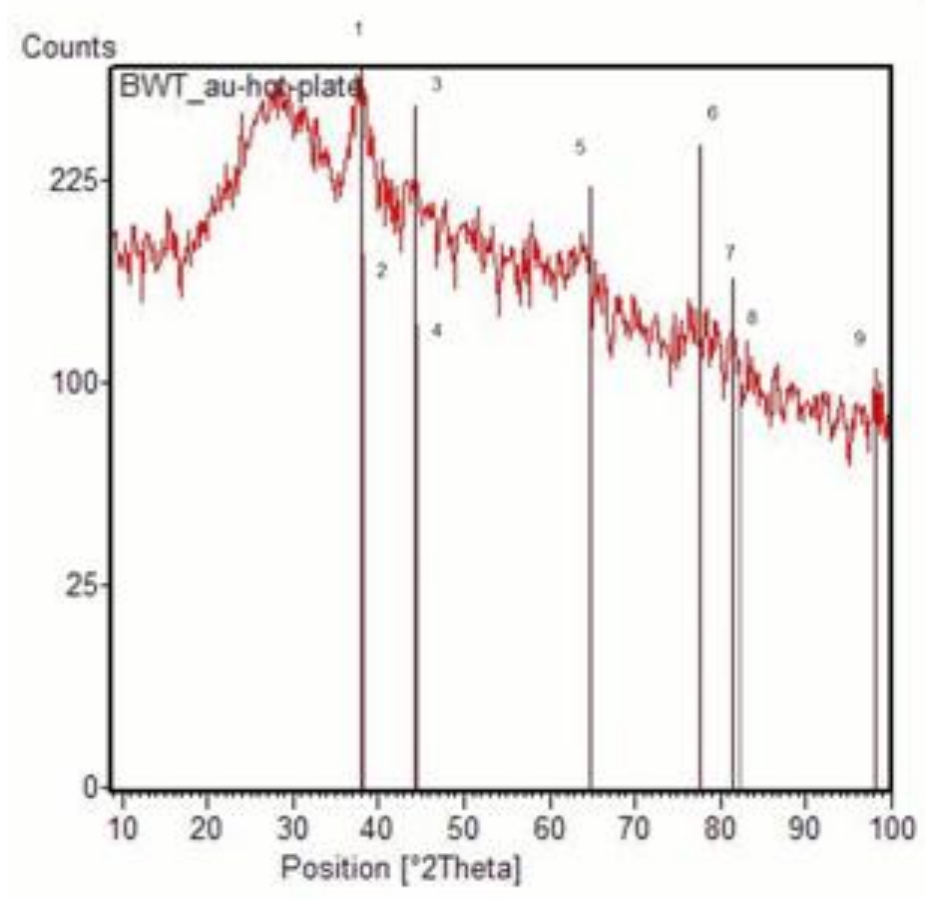

Fig. 40 - Difração do BWT+Au tratado 20h no hotplate com UV.

Os picos encontrados no gráfico acima são identificados pelo programa e reproduzidos na tabela 10 abaixo. Todos os picos da fig. 40 indicam apenas o elemento $\mathrm{Au}$, em sua forma cúbica.

Tabela 10 - Picos encontrados no gráfico BWT+Au

\begin{tabular}{|c|c|}
\hline Número & Pico $(2 \theta)$ \\
\hline 1 & 38,101 \\
\hline 2 & 38,269 \\
\hline 3 & 44,370 \\
\hline 4 & 44,600 \\
\hline 5 & 64,678 \\
\hline 6 & 77,549 \\
\hline 7 & 81,506 \\
\hline 8 & 82,532 \\
\hline 9 & 98,085 \\
\hline
\end{tabular}

Conclui-se que:

- houve cristalização dos elementos da matriz $(\mathrm{Bi}, \mathrm{W}, \mathrm{Te})$ nas análises das amostras de BWT (matriz) feitas sem oxigênio; 
- não houve cristalização dos elementos da matriz nas análises do BWT feito com oxigênio;

- a difração de raios X mostrou a presença de nanopartículas de Au nas análises de BWT-Au produzido com oxigênio; não houve cristalização do BWT nas amostras com Au.

\subsection{Microscopia eletrônica de transmissão e de varredura}

\subsubsection{Microscopia eletrônica de transmissão}

Foram feitas várias análises de microscopia eletrônica de transmissão no filme BWT com nanopartículas de $\mathrm{Au}$, utilizando fragmentos colhidos de uma amostra depositada em substrato de Si. Os resultados são tratados a seguir.

\section{Fragmento 1 de $B W T+A u$}
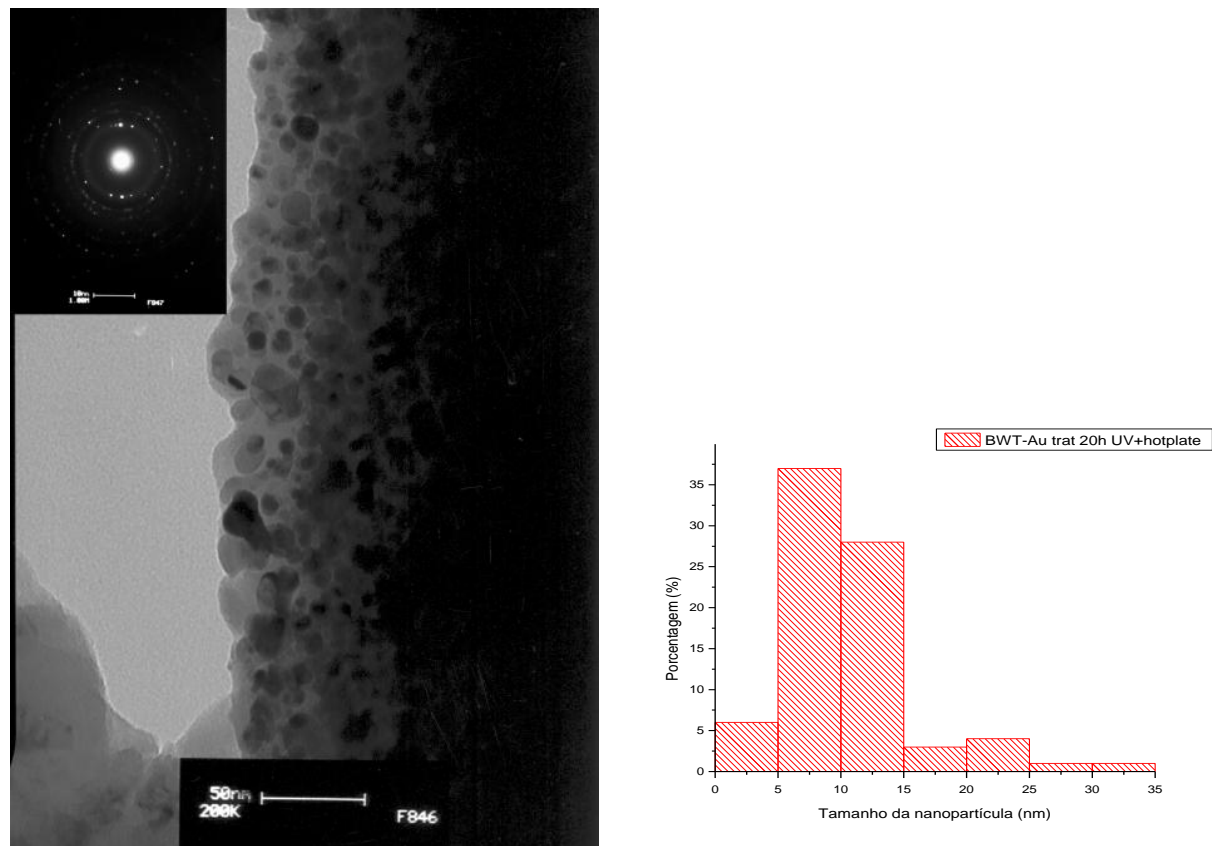

Fig. 41 - Microscopia eletrônica de transmissão do fragmento 1 de filme fino de BWT com nanopartículas de ouro tratado $20 \mathrm{~h}$ com hotplate. A imagem de difração de elétrons e o histograma referente à distribuição por tamanho das nanopartículas são também mostrados. 
A difração de elétrons presente no canto superior esquerdo da Fig. 41 está relacionada aos nanocristais de Au presentes na amostra. Pode-se verificar no histograma nanopartículas que variam de $3 \mathrm{~nm}$ a $32 \mathrm{~nm}$, predominando aquelas na faixa de $5 \mathrm{~nm}$ a $15 \mathrm{~nm}$. A análise por EDS (Fig. 42) mostra presença de cobre, proveniente da telinha na qual a amostra é preparada.

\section{Label A:}

d:\{dx4\}mthin\}usrif846.spc

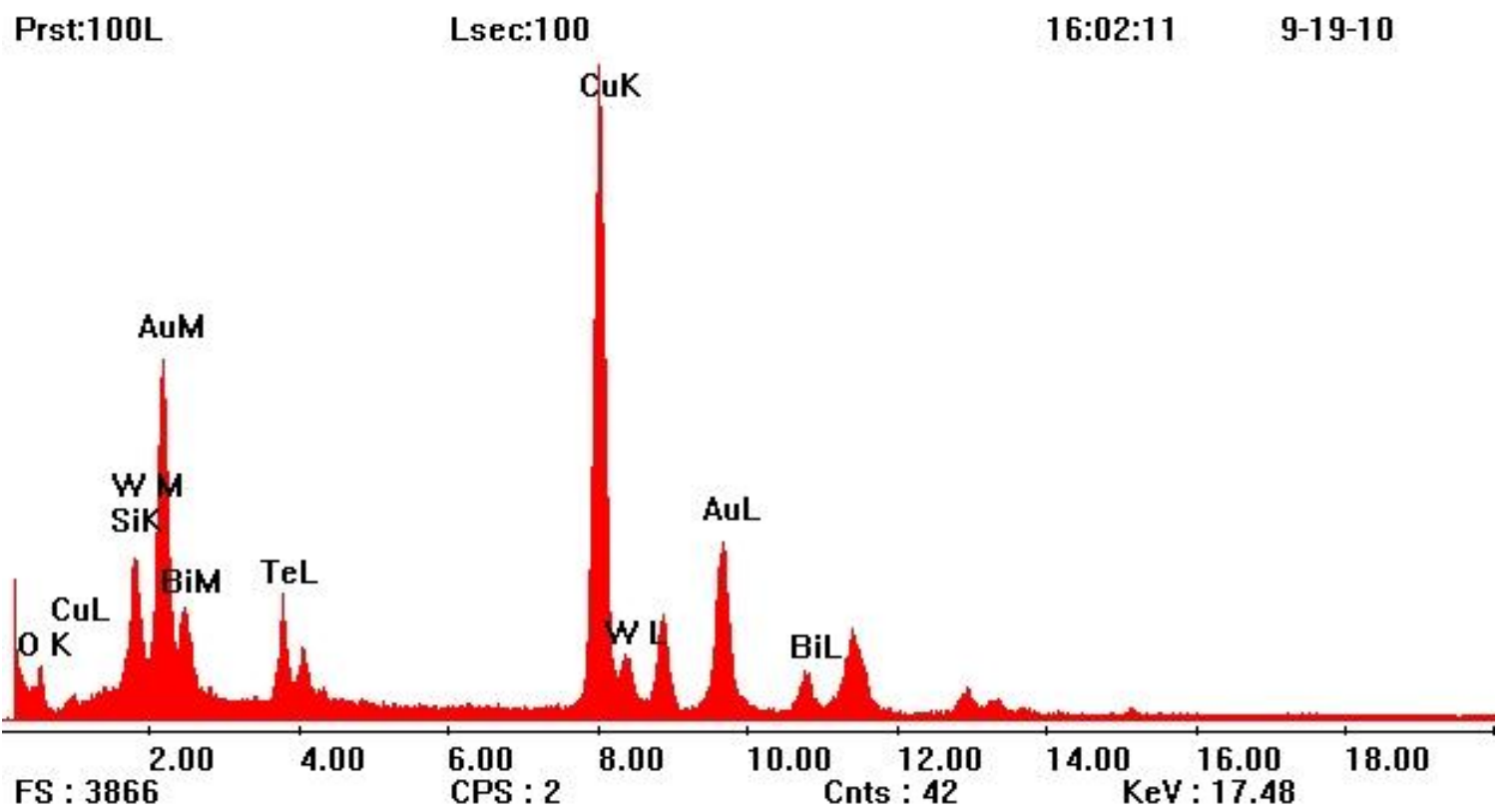

Fig. 42 - EDS do fragmento 1 do filme BWT+Au tratado 20h com hotplate

O espectro do EDS acima mostra os picos referentes aos elementos da matriz ( $\mathrm{Bi}, \mathrm{W}$ e Te) bem como a presença de Au.

Fragmento 2 de $B W T+A u$

Os resultados do fragmento 2 da mesma amostra de BWT com Au são mostrados a seguir, na Fig. 43. 

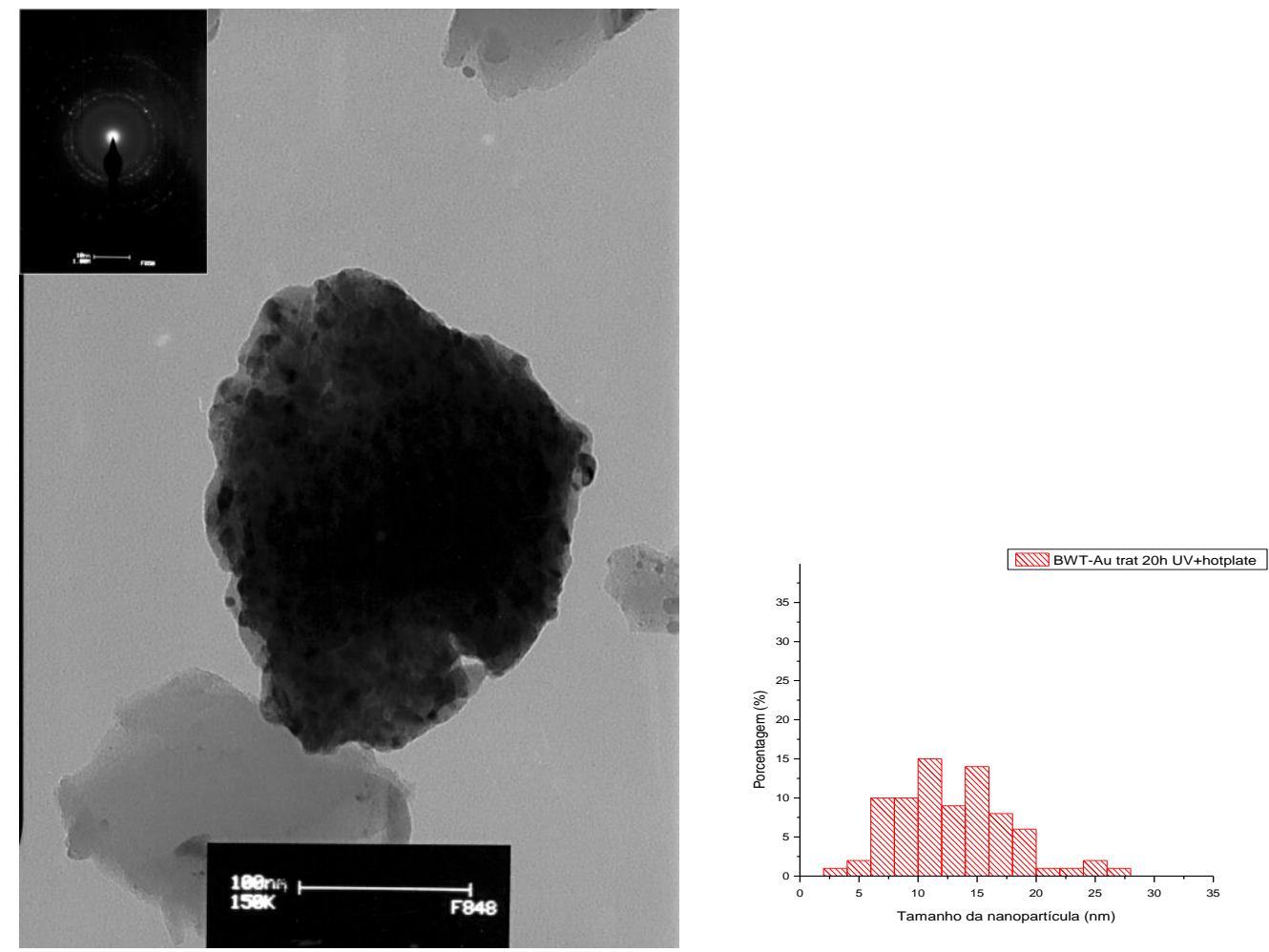

Fig. 43 - Microscopia eletrônica de transmissão do fragmento 2 de filme fino de BWT com nanopartículas de ouro tratado $20 \mathrm{~h}$ com hotplate. A imagem de difração de elétrons e o histograma referente à distribuição por tamanho das nanopartículas são também mostrados.

Podemos observar a presença de nanopartículas com tamanho de $4 \mathrm{~nm}$ a $26 \mathrm{~nm}$.

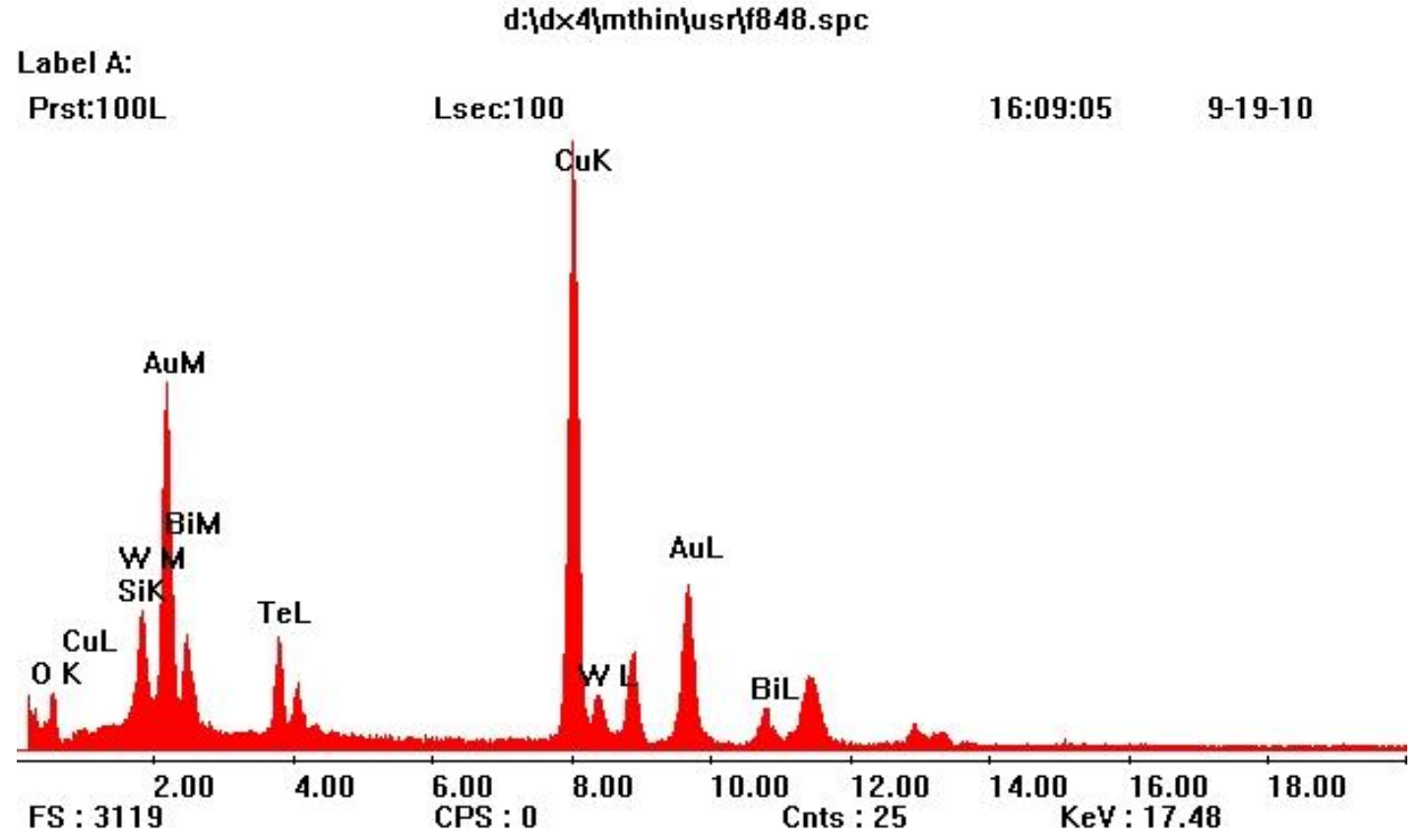

Fig. 44 - EDS do fragmento 2 do filme BWT+Au tratado 20h com hotplate 
O espectro do EDS (Fig. 44) acima mostra os picos referentes aos elementos da matriz ( $\mathrm{Bi}, \mathrm{W}$ e $\mathrm{Te}$ ) bem como a presença de $\mathrm{Au}$, tal como no primeiro fragmento.

\section{Fragmento 3 de $B W T+A u$}

Para o fragmento 3, conforme mostra a Fig. 45 a seguir, notamos nanopartículas com tamanho de $5 \mathrm{~nm}$ a $24 \mathrm{~nm}$.
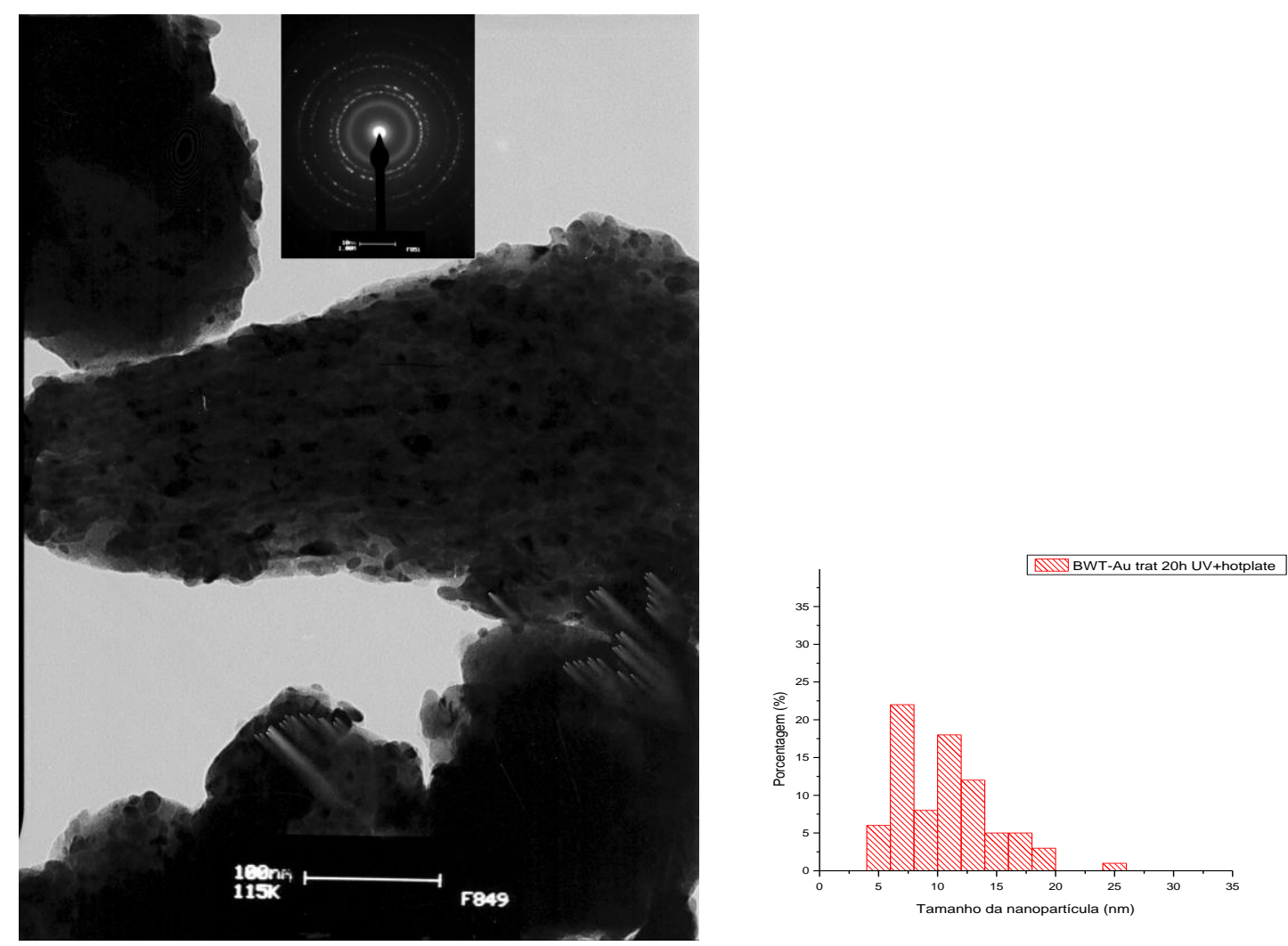

Fig. 45 - Microscopia eletrônica de transmissão do fragmento 2 de filme fino de BWT com nanopartículas de ouro tratado $20 \mathrm{~h}$ com hotplate. A imagem de difração de elétrons e o histograma referente à distribuição por tamanho das nanopartículas são também mostrados. 


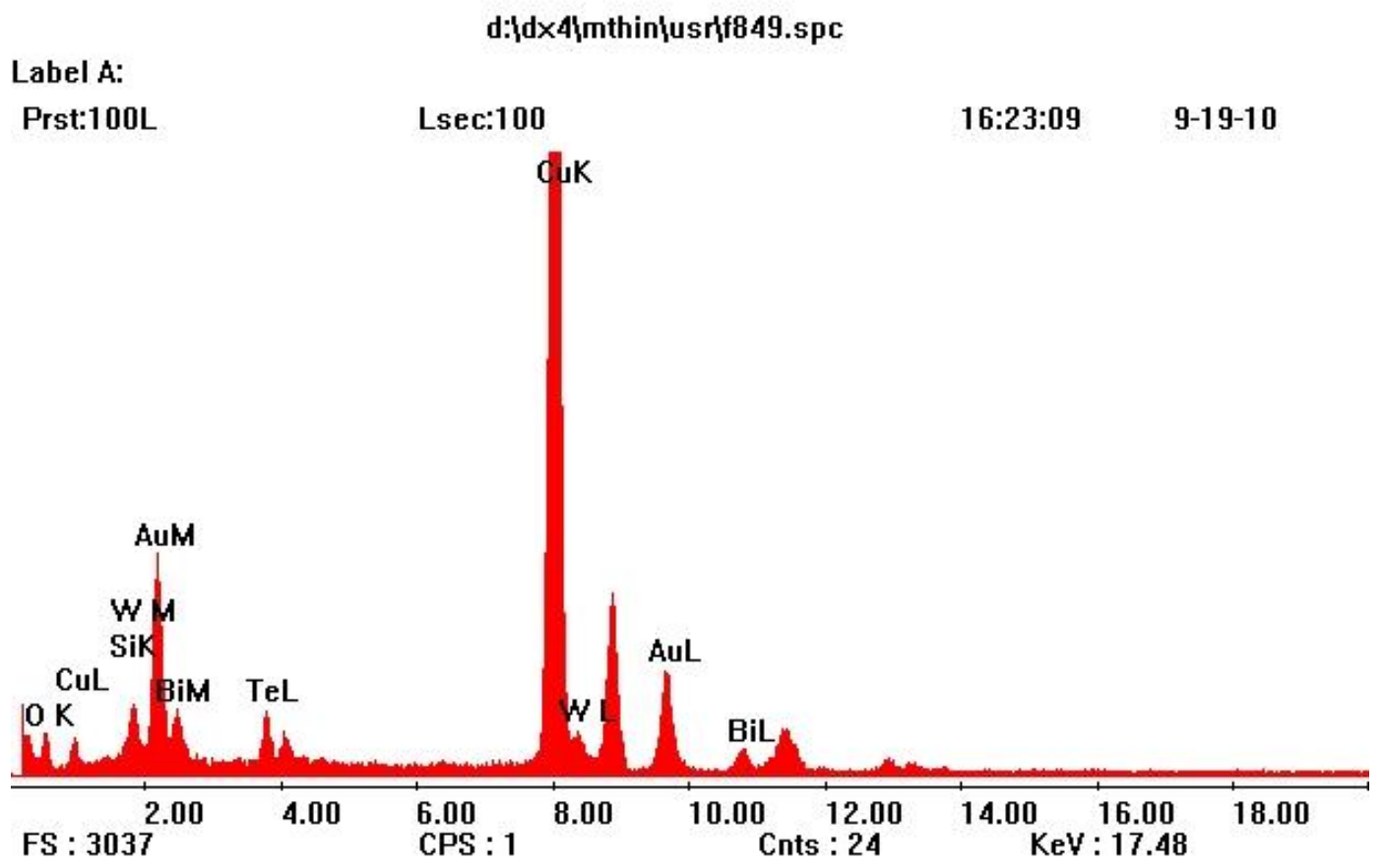

Fig. 46 - EDS do fragmento 3 do filme BWT+Au tratado 20h com hotplate

O espectro do EDS (Fig. 46) acima mostra os picos referentes aos elementos da matriz ( $\mathrm{Bi}, \mathrm{W}$ e $\mathrm{Te}$ ) bem como a presença de $\mathrm{Au}$, tal como nos fragmentos anteriores.

Nas imagens de difração dos três fragmentos, existem vários anéis de difração, o que indica a formação de nanopartículas de ouro policristalinos ou com diferentes estruturas monocristalinas.

Portanto, as medidas feitas a partir da microscopia eletrônica de transmissão mostraram presença de nanopartículas de $\mathrm{Au}$, de acordo com as espectativas.

\subsubsection{Microscopia eletrônica de varredura}

Seguem os resultados obtidos por microscopia eletrônica de varredura para o filme BWT antes (Fig. 47) e após (Fig. 48) a remoção do fotorresiste. 


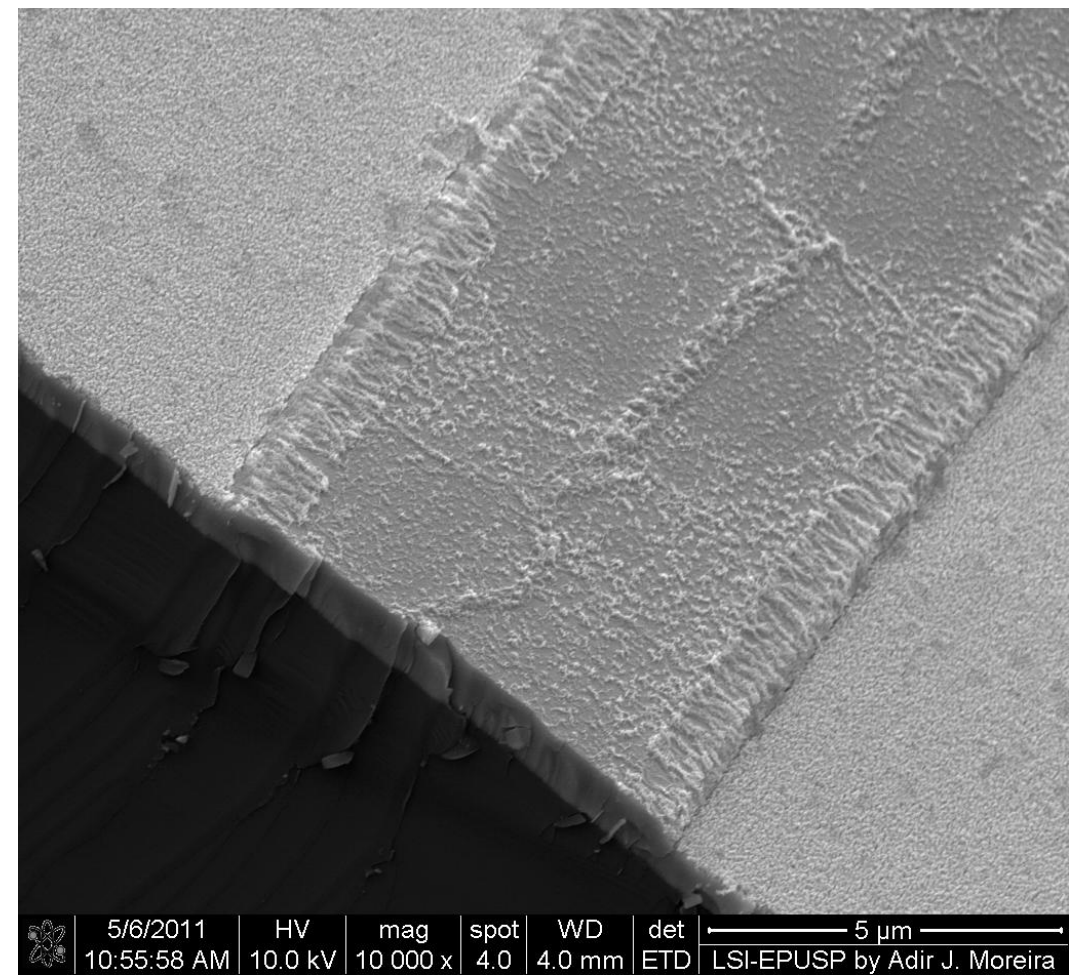

Fig. 47 - Imagem do guia de onda planar de BWT do tipo "rib" antes da remoção do fotorresiste. O guia é de 6 $\mu \mathrm{m}$ de largura e sofreu corrosão RIE com $25 \mathrm{sccm}$ de $\mathrm{SF}_{6}$

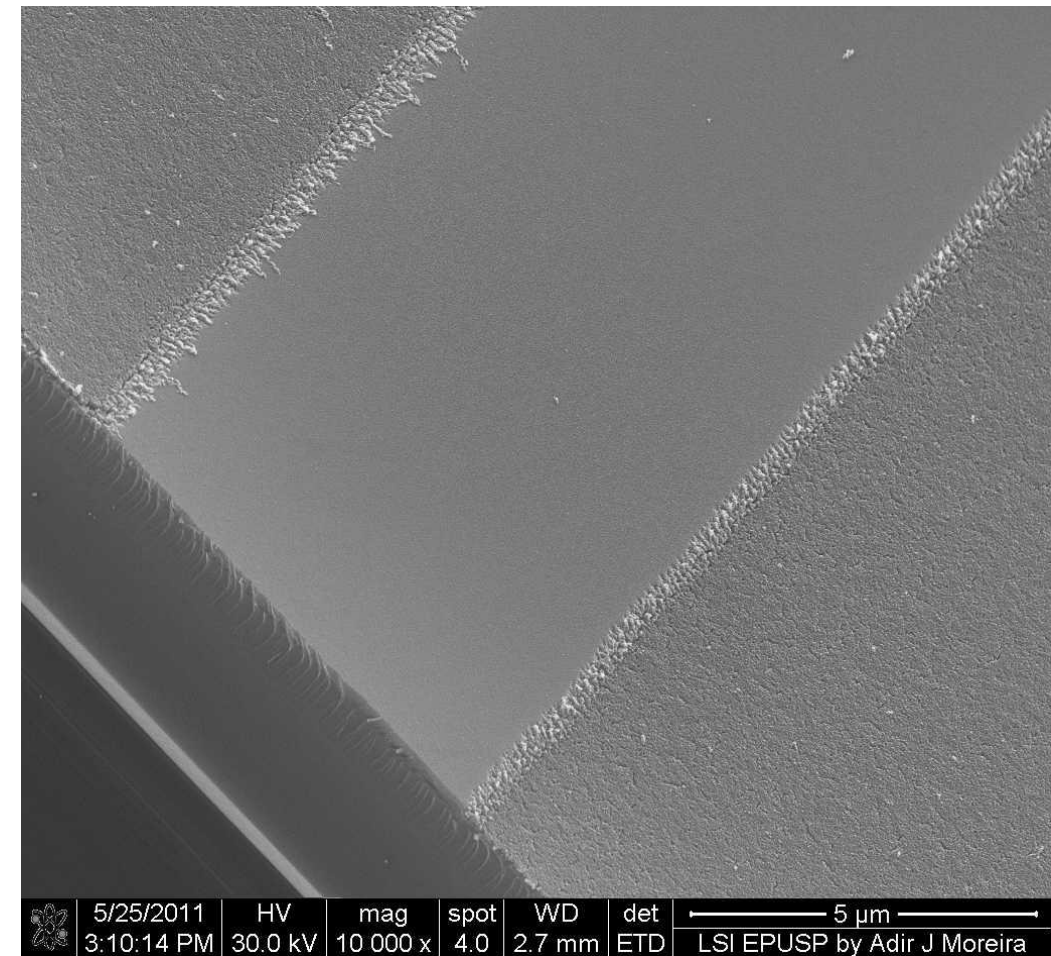

Fig. 48- Imagem do guia de onda planar do tipo "rib" com $5 \mu \mathrm{m}$ de largura e após corrosão RIE com 25 sccm de $\mathrm{SF}_{6}$, após remoção do fotorresiste. 
A imagem do guia de onda após a remoção do fotorresiste mostrou rugosidade pouco significativa no guia. Isso mostra a eficácia do processo de sputtering para fabricar filmes finos para dispositivos fotônicos. Por outro lado, a rugosidade foi mais significativa na região fora do "rib". Dois fatores podem ter contribuído para isso: a dificuldade em retirar totalmente o fotorresiste com o Microstripper 2001 ou o processo anterior de corrosão RIE do filme para a formação do 'rib'.

A baixa rugosidade dos guias produzidos na superfície do guia contribuiu para o bom guiamento do feixe de luz a $632,8 \mathrm{~nm}$.

\subsection{Caracterização óptica dos guias de onda e simulações}

Foram caracterizados os guias de onda de BWT com larguras entre 3 e $10 \mu \mathrm{m}$, por meio do arranjo mostrado no item 3.5.7.. Os guias foram identificadas pelo fluxo de $\mathrm{SF}_{6}$ utilizado durante a remoção do filme BWT: 15 e $25 \mathrm{sccm}$.

Mostramos a seguir os resultados das perdas por propagação obtidos nos guias preparados nas condições acima descritas, ou seja, usando $15 \mathrm{sccm}$ de $\mathrm{SF}_{6}$ e $25 \mathrm{sccm}$ de $\mathrm{SF}_{6}$ :

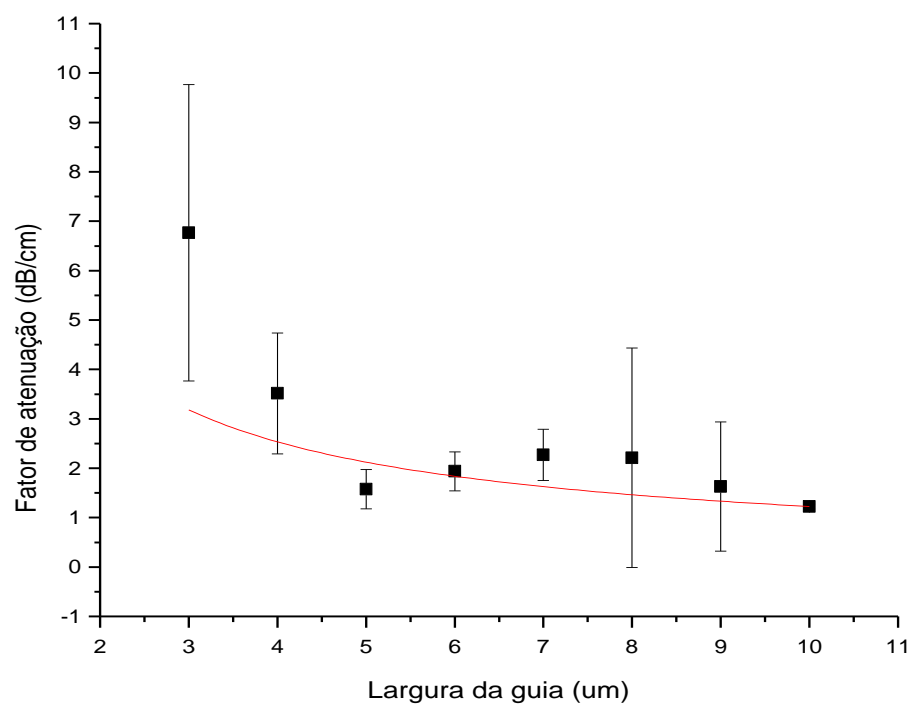

Fig. 49 - Perdas por propagação (em dB/cm) nos guias de onda BWT obtidos após litografia e corrosão do filme com $15 \mathrm{sccm}$ de $\mathrm{SF}_{6}$, para um feixe de laser de $632,8 \mathrm{~nm}$. 


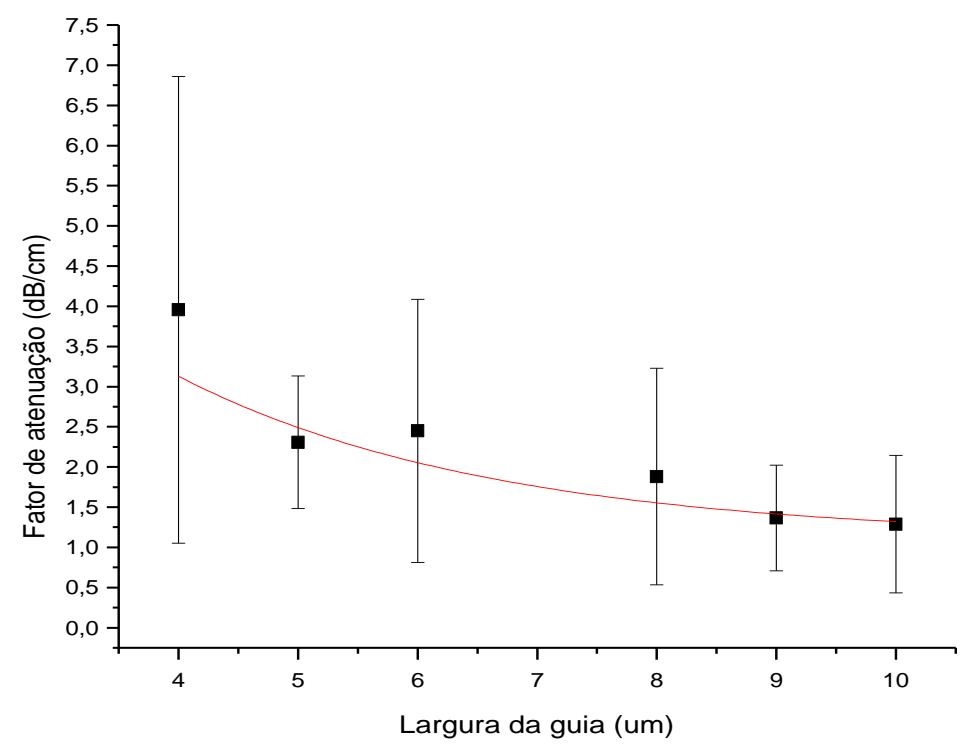

Fig. 50 - Perdas por propagação (em dB/cm) nos guias de onda BWT obtidos após litografia e corrosão do filme com $25 \mathrm{sccm}$ de $\mathrm{SF}_{6}$, para um feixe de laser de 632,8 $\mathrm{nm}$.

Pode-se notar que a perda por propagação diminui com o aumento da largura dos guias. Notamos que os resultados das atenuações para os guias de $3 \mu \mathrm{m}$ de largura produzidos com $15 \mathrm{sccm}$ de $\mathrm{SF}_{6}$ (Fig. 49) e os guias de igual largura, mas produzidos com $25 \mathrm{sccm}$ de $\mathrm{SF}_{6}$ (Fig. 50) são consideravelmente diferentes. Isto é decorrente das limitações da litografia. Os resultados encontrados são similares aos obtidos em filmes $\mathrm{PbO}-\mathrm{GeO}_{2}$ e $\mathrm{TeO}_{2}-\mathrm{ZnO}$ em trabalho de doutorado realizado pelo grupo [2]. Também notamos que a presença do espalhamento da luz contribuiu para as medidas terem variâncias significativas.

De qualquer forma, os valores das perdas por propagação, em torno de 2,0 dB/cm, podem ser considerados satisfatórios para guias de ondas passivos.

Na Fig. 51 a seguir mostramos uma das imagens obtidas durante o guiamento de luz em $632,8 \mathrm{~nm}$. 


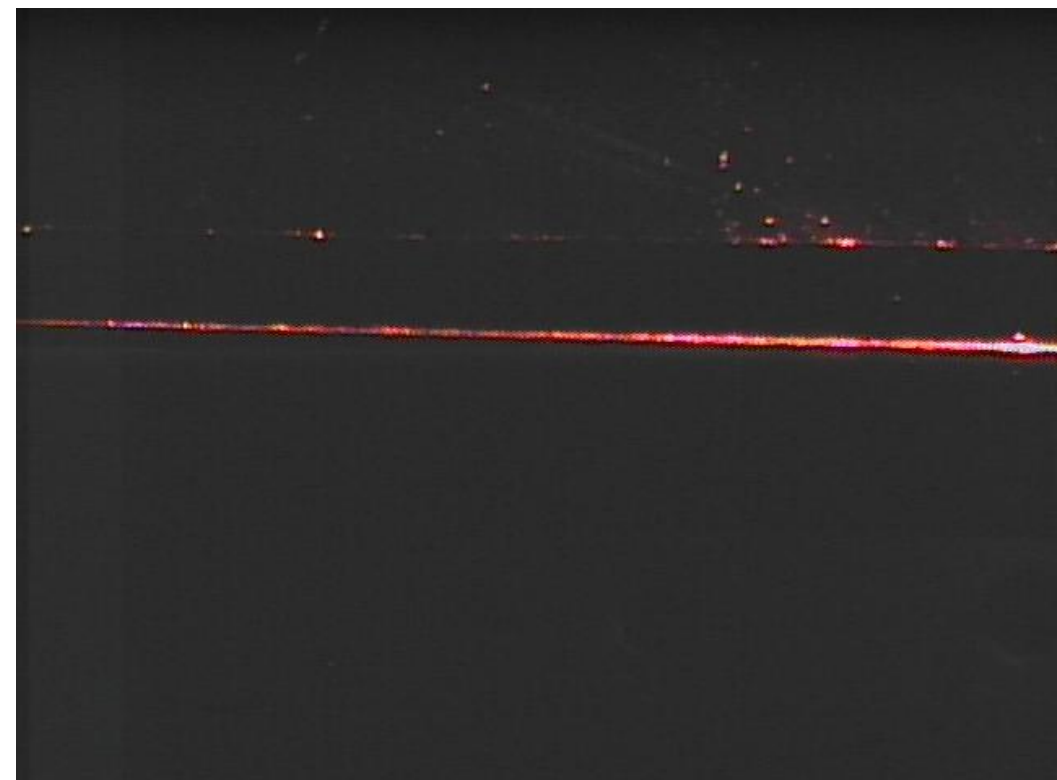

Fig. 51 - Transmissão de um feixe de laser de 632,8 nm em um guia BWT de $9 \mu \mathrm{m}$ de largura, produzida utilizando $25 \mathrm{sccm}$ de $\mathrm{SF}_{6}$ para remoção do filme.

Foram feitas, também, medições com laser de itérbio cujo comprimento de onda está situado no infravermelho próximo $(1050 \mathrm{~nm})$. As atenuações medidas para $1050 \mathrm{~nm}$ foram, em geral, ligeiramente maiores do que as encontradas no guiamento a $632,8 \mathrm{~nm}$, conforme demonstram os resultados apresentados nas fig. 52 e 53 abaixo:

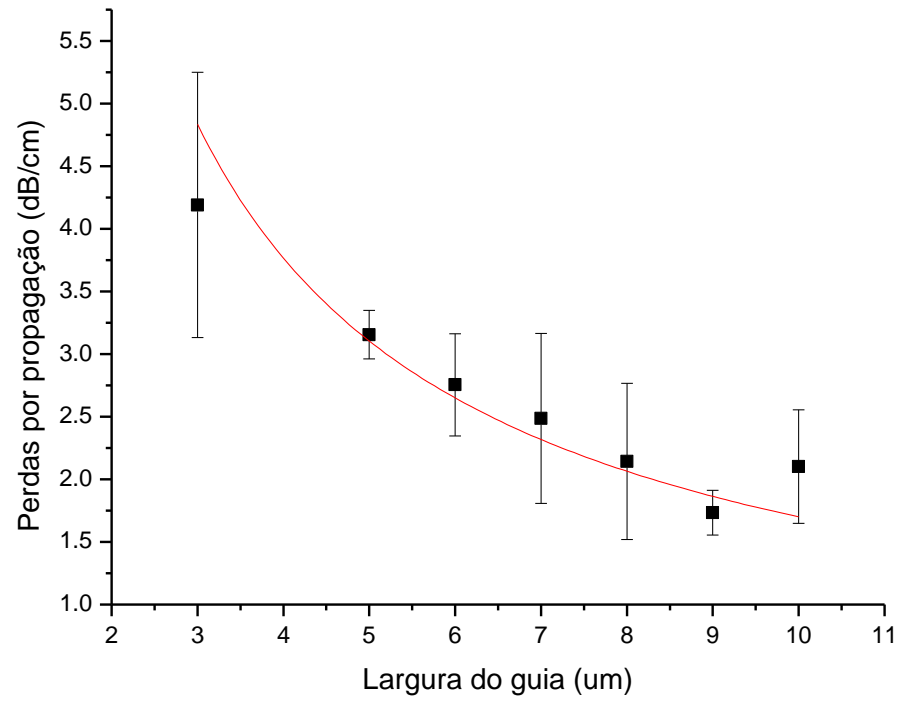

Fig. 52 - Perdas por propagação $(\mathrm{em} \mathrm{dB} / \mathrm{cm}$ ) nos guias de onda BWT obtidos após litografia e corrosão do filme com $15 \mathrm{sccm}$ de $\mathrm{SF}_{6}$, para comprimento de onda de $1050 \mathrm{~nm}$. 


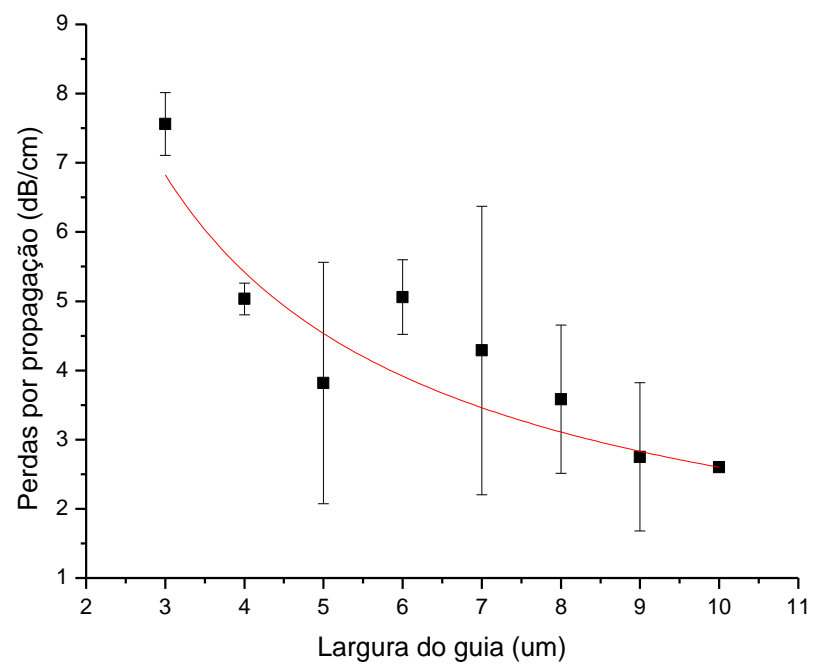

Fig. 53 - Perdas por propagação $(\mathrm{em} \mathrm{dB} / \mathrm{cm}$ ) nos guias de onda BWT obtidos após litografia e corrosão do filme com $25 \mathrm{sccm}$ de $\mathrm{SF}_{6}$, para um feixe de laser de $1050 \mathrm{~nm}$

Como no caso do guiamento do laser de 632,8 nm, observamos uma diminuição nos valores de atenuação com o aumento da largura dos guias. Para os guias produzidos com 15 sccm de $\mathrm{SF}_{6}$ observamos atenuação em torno de $2,0 \mathrm{~dB} / \mathrm{cm}$, para larguras superior a $6 \mu \mathrm{m}$. Para os guias feitos com $25 \mathrm{sccm}$ de $\mathrm{SF}_{6}$ observamos atenuação em torno de $3,5 \mathrm{~dB} / \mathrm{cm}$ para guias com largura superior a $6 \mu \mathrm{m}$.

Os guias produzidos foram submetidos à simulação, para determinar a natureza do guiamento, segundo os modos de propagação da luz (TE): multimodo ou monomodo. Para tanto, conforme explicado anteriormente, foi usado o programa Selene 3.2.02 da BBV Software.

Quanto ao modo de propagação, os guias de ondas BWT simulados, apresentaram um guiamento multimodo (TE). Foram consideradas nas simulações, larguras de linhas de 3 a 10 $\mu \mathrm{m}$, pois um fator limitante para as construção dos guias é a resolução dos processos de fabricação. As linhas com larguras menores do que $3 \mu \mathrm{m}$ não apresentam uma boa definição para os processos convencionais de litografia óptica e corrosão.

Nota-se que o número de modos aumenta de acordo com a largura dos guias. Os resultados das simulações dos guias com mesma largura, porém com diferentes fluxos de $\mathrm{SF}_{6}$ também diferem. Para os guias produzidos com $25 \mathrm{sccm}$ de $\mathrm{SF}_{6}$, o número de modos tende a aumentar; isto pode ser atribuído ao fato destes guias terem h_core maior. As figuras 54 e 55 
mostram o perfil de confinamento do campo elétrico $(\mathrm{V} / \mathrm{m})$ e os modos de propagação na estrutura dos guias tipo "rib" de BWT em função da largura do guia (W_core), para comprimento de onda de $632,8 \mathrm{~nm}$ :
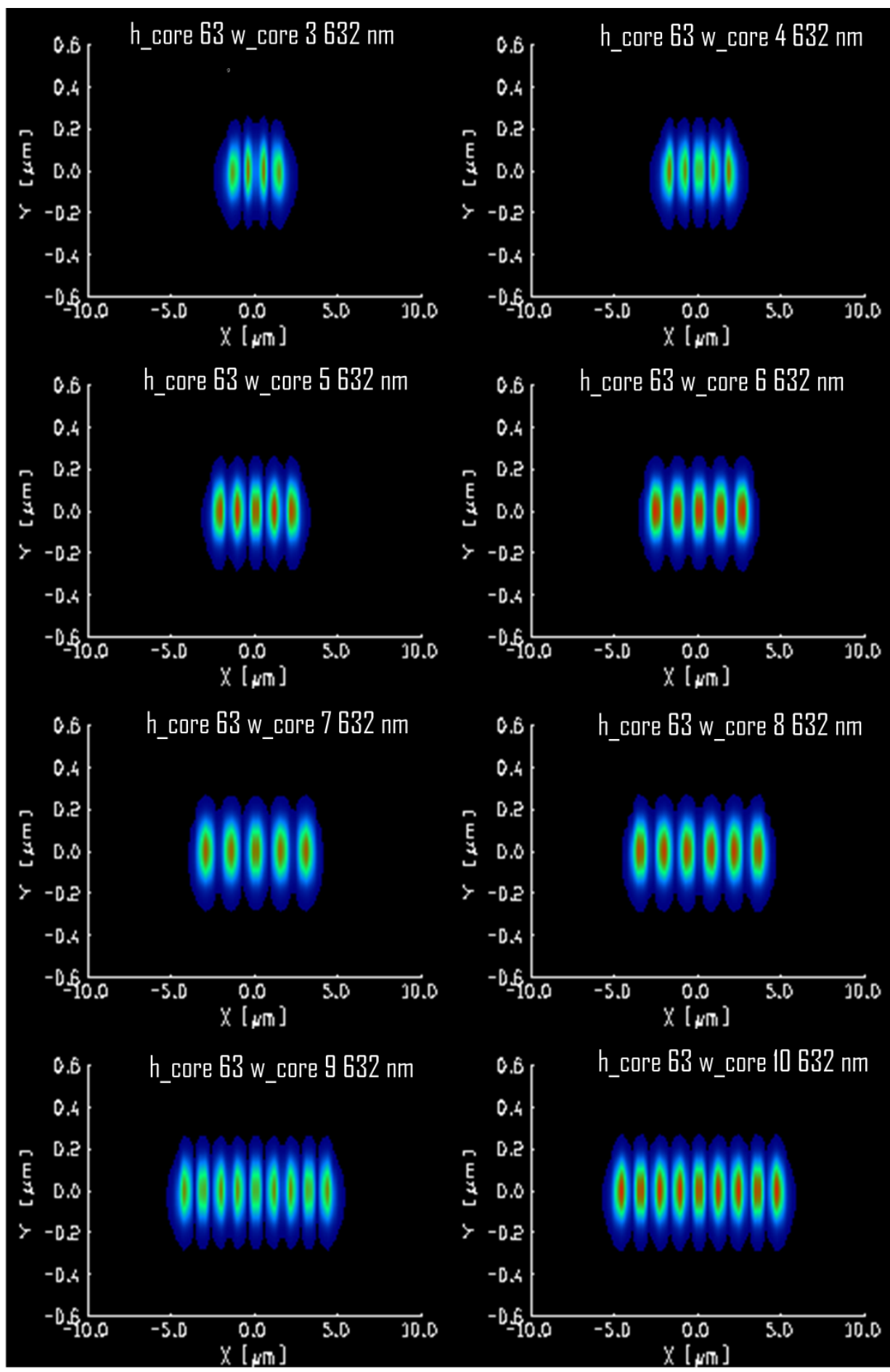

Fig. 54 - Simulação dos modos de propagação do campo elétrico para comprimento de onda de 632,8 nm nos guias de onda BWT produzidos com $15 \mathrm{sccm}$ de $\mathrm{SF}_{6}$ para diferentes $\mathrm{W} \_$core. $\mathrm{O}$ h_core dos guias é de $63 \mathrm{~nm}$. 

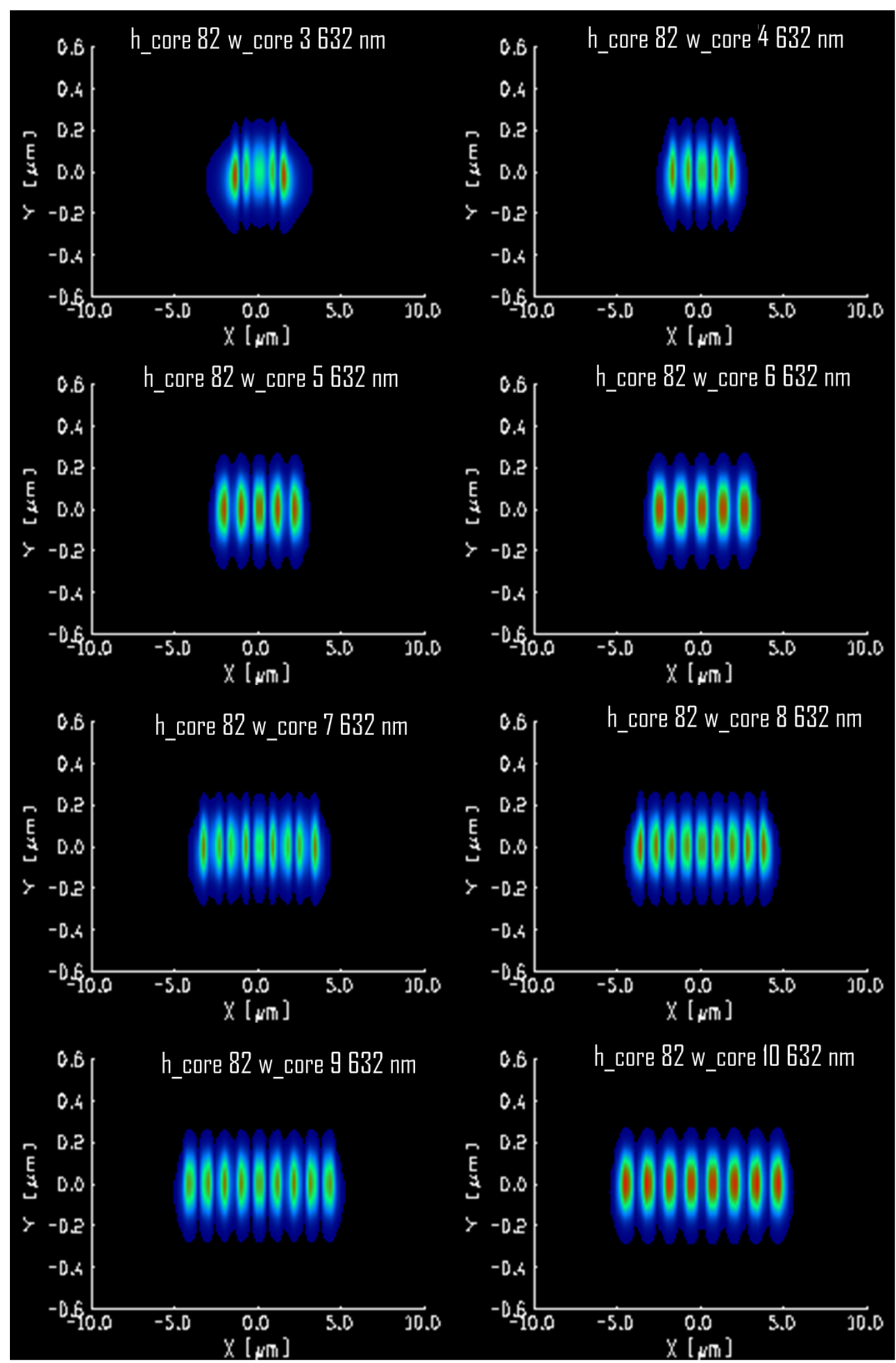

Fig. 55 - Simulação dos modos de propagação do campo elétrico para comprimento de onda de 632,8 nm nos guias de onda BWT produzidos com $25 \mathrm{sccm}$ de $\mathrm{SF}_{6}$ para diferentes W_core. O h_core dos guias é de $82 \mathrm{~nm}$. 
Para guiamento em $\lambda=1050 \mathrm{~nm}$, os resultados podem ser vistos nas fig. 56 e 57 :
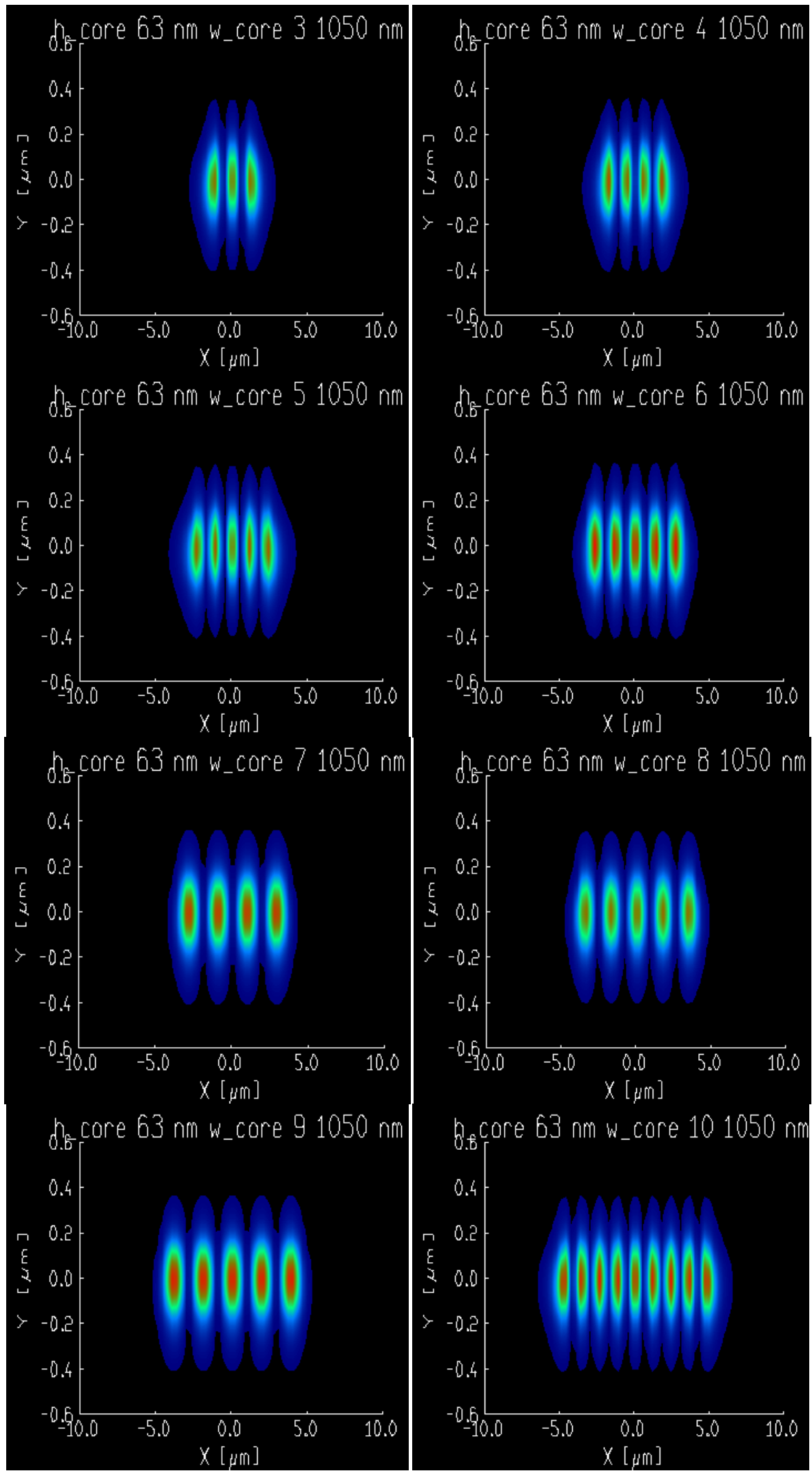

Fig. 56 - Simulação dos modos de propagação do campo elétrico nos guias de onda BWT produzidos com 15 sccm de $\mathrm{SF}_{6}$ para diferentes $\mathrm{W} \_$core, em comprimento de onda de $1050 \mathrm{~nm}$. 

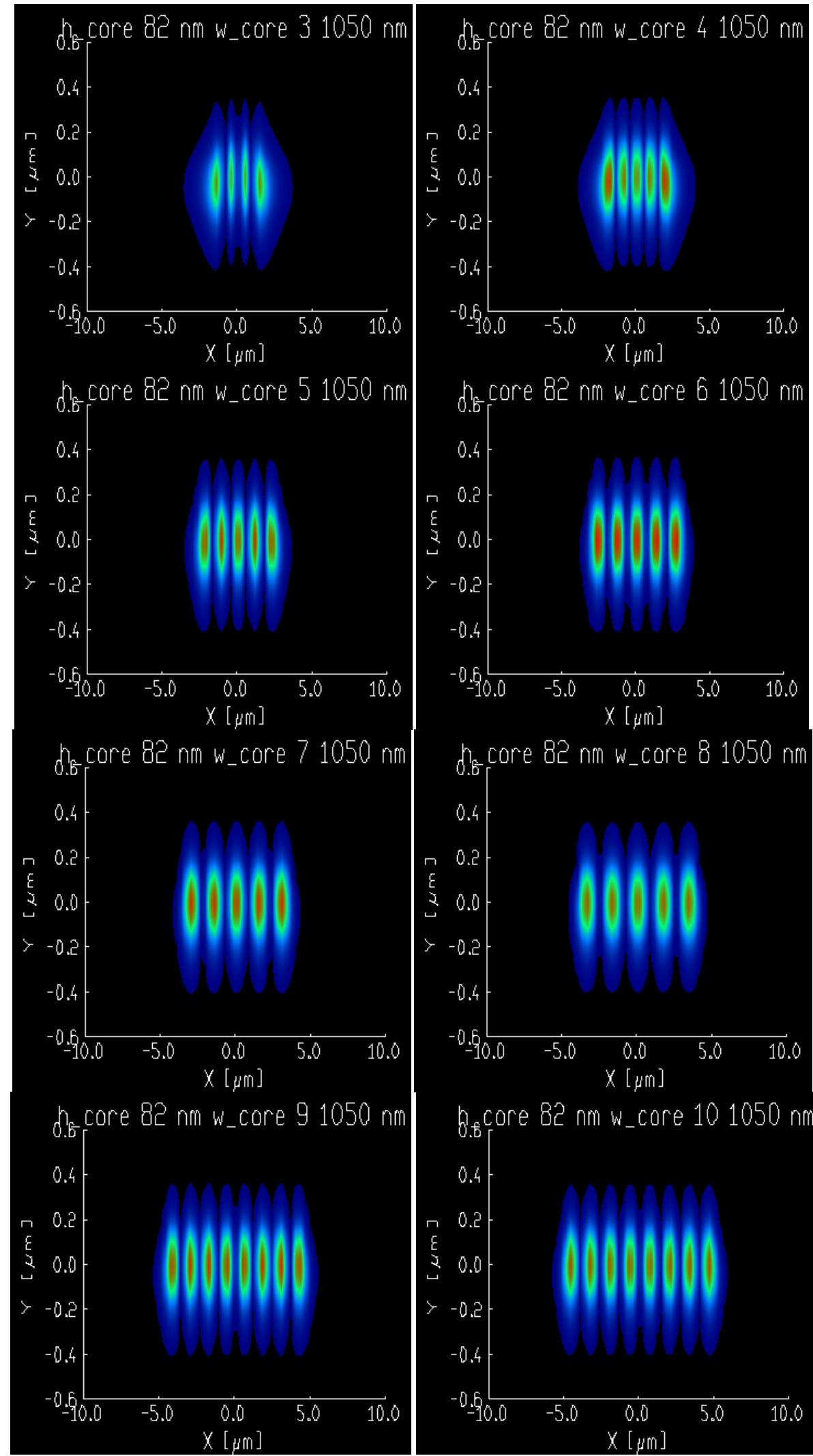

Fig. 57 - Simulação dos modos de propagação do campo elétrico nos guias de onda BWT produzidos com 25 sccm de $\mathrm{SF}_{6}$ para diferentes $\mathrm{W}_{\text {_core, }}$ em comprimento de onda de $1050 \mathrm{~nm}$. 
Para guiamento em $\lambda=1530 \mathrm{~nm}$, os resultados estão mostrados a seguir (Fig. 58 e 59):
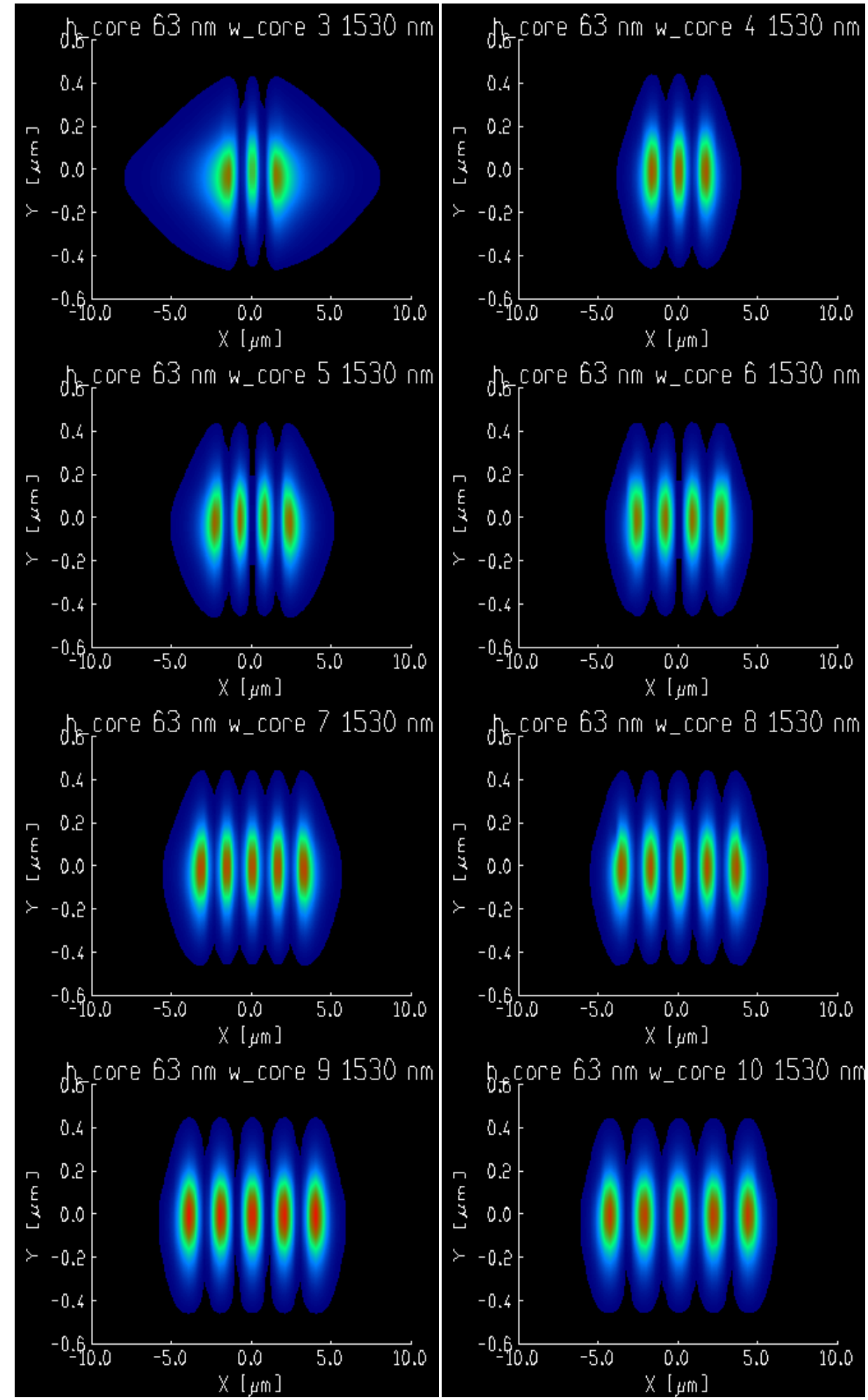

Fig. 58 - Simulação dos modos de propagação do campo elétrico nos guias de onda BWT produzidos com 15 sccm de $\mathrm{SF}_{6}$ para diferentes W_core, em comprimento de onda de $1530 \mathrm{~nm}$. 

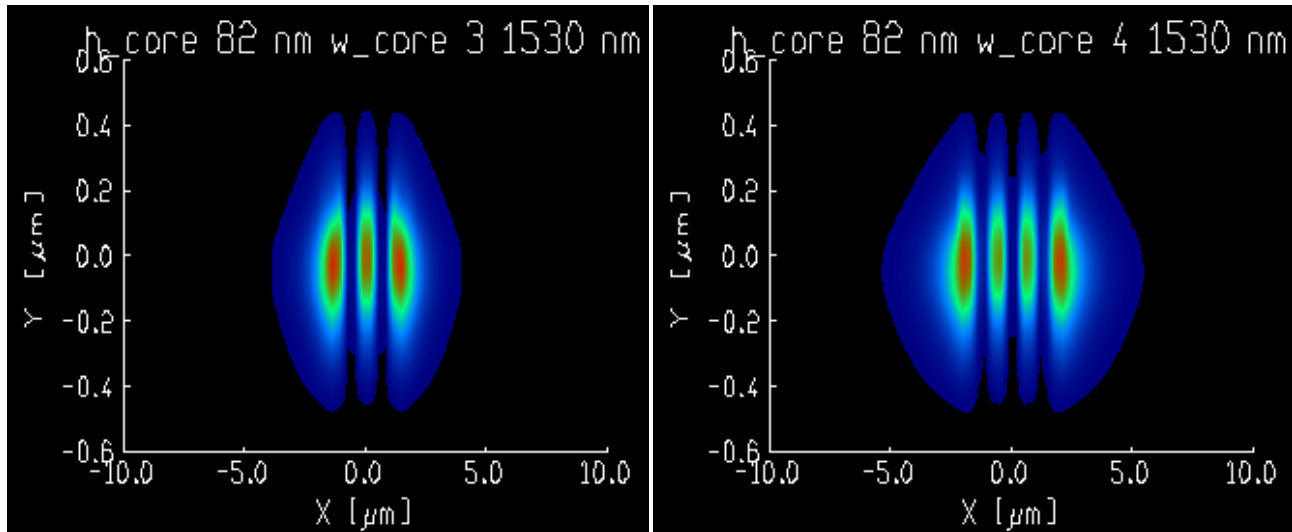

d. core 82 nm $w_{-}$core 51530 nm d.t. core $82 \mathrm{~nm} \mathrm{w}_{-}$core $61530 \mathrm{~nm}$ 0.4

$\begin{array}{cc}7 & 0.2 \\ E & \\ z & 0.0\end{array}$

$\succ-0.2$

$-0.4$

$-0.6$

$-5.0$

0.0

10.0

d. core $82 \mathrm{~nm} w_{\text {_core }} 71530 \mathrm{~nm}$
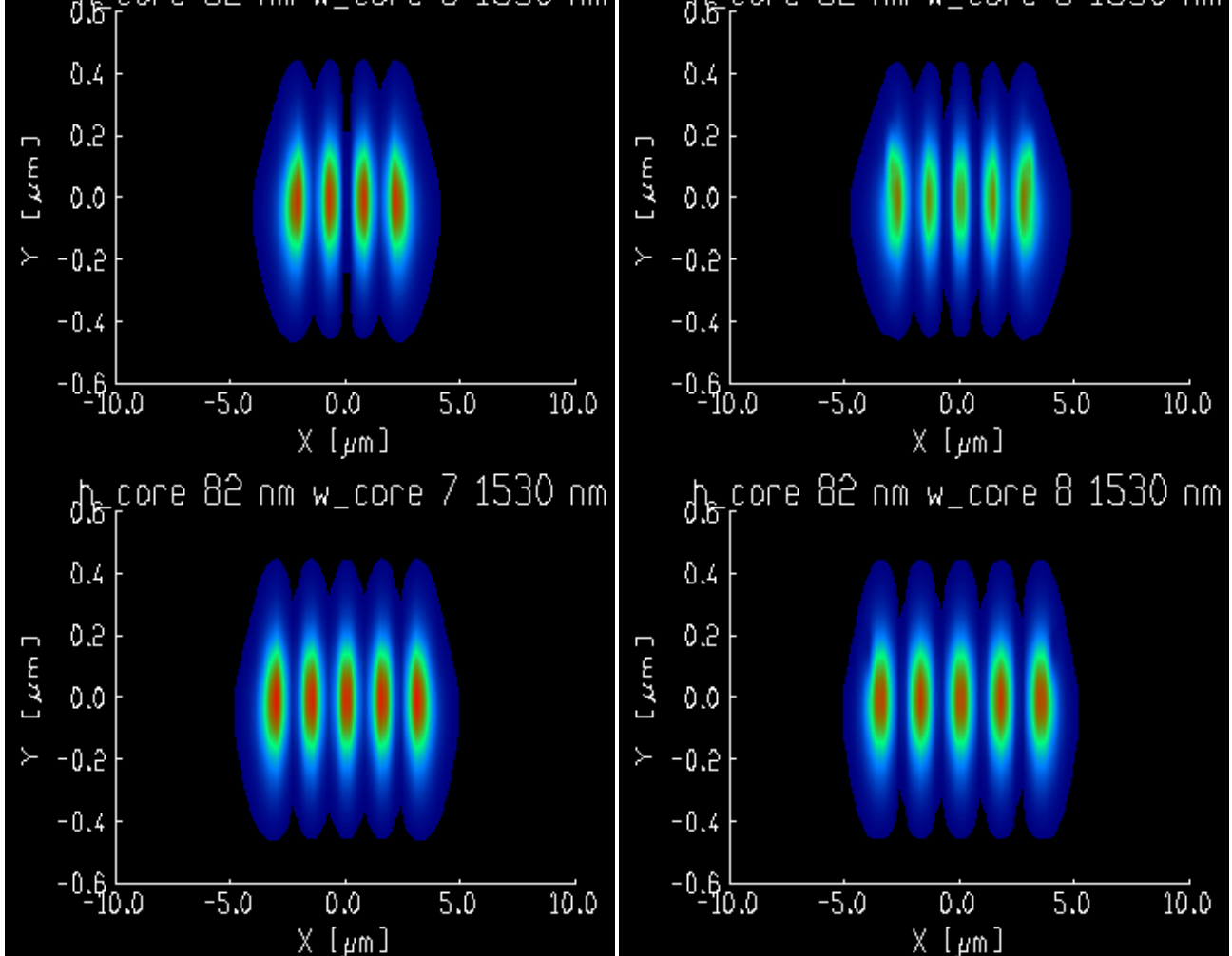

d. core 82 nm $w_{-}$core 91530 nm b.6core 82 nm w_core 101530 nm 0.4

$\begin{array}{ll} & 0.2 \\ \xi & \\ \text { 省 } & 0.0\end{array}$

工 0.0

$\succ-0.2$

$-0.4$

$-0.60 .0$

$-5.0$
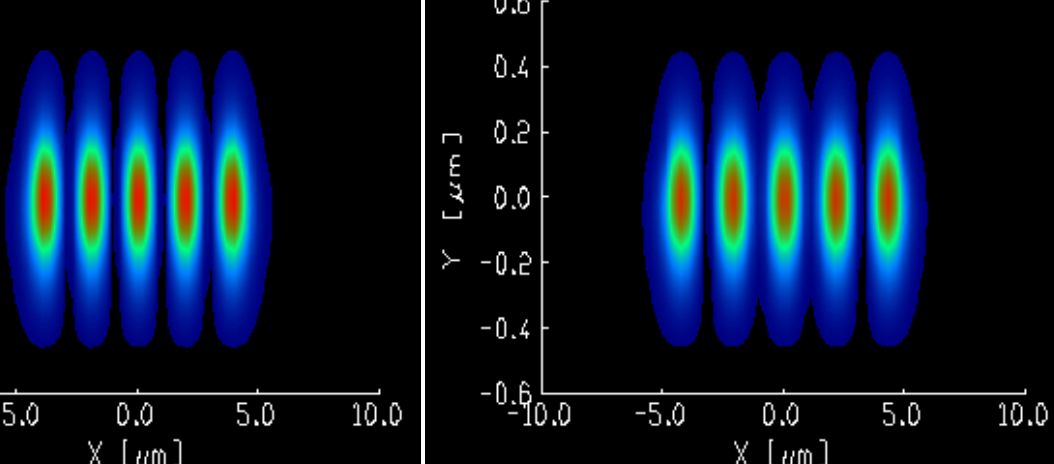

Fig. 59 - Simulação dos modos de propagação do campo elétrico nos guias de onda BWT produzidos com 25

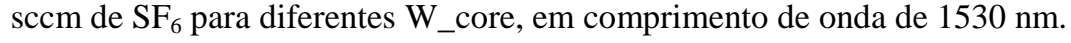


Foram feitas simulações para determinar os valores de h_core necessários para guiamento monomodo nos comprimentos de onda de 632,8 nm, $1050 \mathrm{~nm}$ e $1530 \mathrm{~nm}$. Os resultados são mostrados a seguir, na tabela 11:

Tabela 11 - Resultados de h_core para guias monomodos, em função do comprimento de onda da luz guiada

\begin{tabular}{|c|c|c|c|}
\hline W_core $(\mu \mathrm{m})$ & $\begin{array}{c}h \_c o r e(\mathrm{~nm}) \text { para } \lambda= \\
632,8 \mathrm{~nm}\end{array}$ & $\begin{array}{c}h \_c o r e(\mathrm{~nm}) \text { para } \\
\lambda=1050 \mathrm{~nm}\end{array}$ & $\begin{array}{c}h \_ \text {core }(\mathrm{nm}) \text { para } \\
\lambda=1530 \mathrm{~nm}\end{array}$ \\
\hline 3 & 5,5 & 8,6 & 14,8 \\
\hline 5 & 1,9 & 3,3 & 5,3 \\
\hline 7 & 0,9 & 1,7 & 2,7 \\
\hline 10 & 0,4 & 0,8 & 1,3 \\
\hline
\end{tabular}

Existe o risco de haver espalhamento lateral do campo, para guias monomodos, particularmente nos mais largos, independente do comprimento de onda da luz guiada, como se pode verificar na simulação de um guia monomodo de $7 \mu \mathrm{m}$ de largura guiando luz de 632,8 nm (Fig. 60-a), 1050 nm (Fig. 60-b) e 1530 nm (Fig. 60-c).
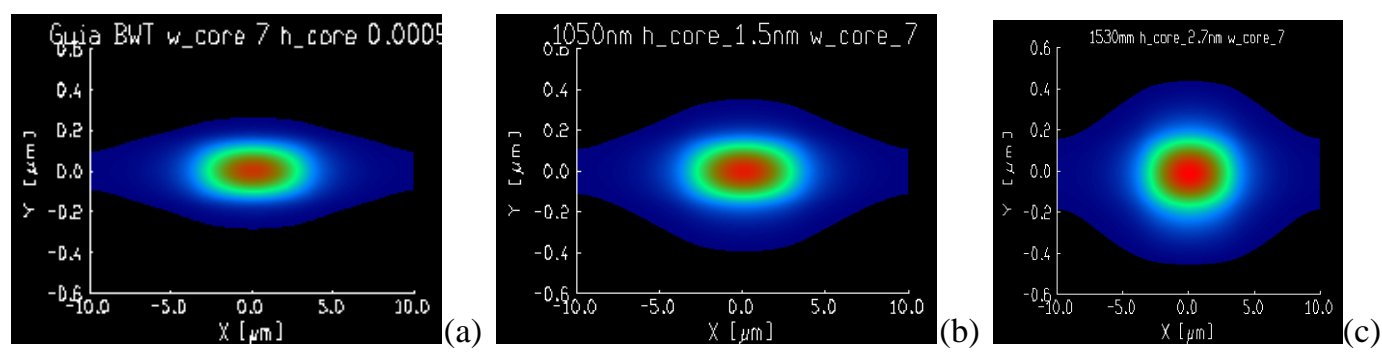

Fig. 60 - Resultado da simulação de um guia monomodo de $7 \mu \mathrm{m}$ para guiamento de luz a: (a) 632,8 nm; (b) $1050 \mathrm{~nm}$; (c) $1530 \mathrm{~nm}$

O referido alargamento é menos acentuado em guias com larguras de $5 \mu \mathrm{m}$, como se pode ver na Fig. 61 para luz guiada de $1530 \mathrm{~nm}$ :

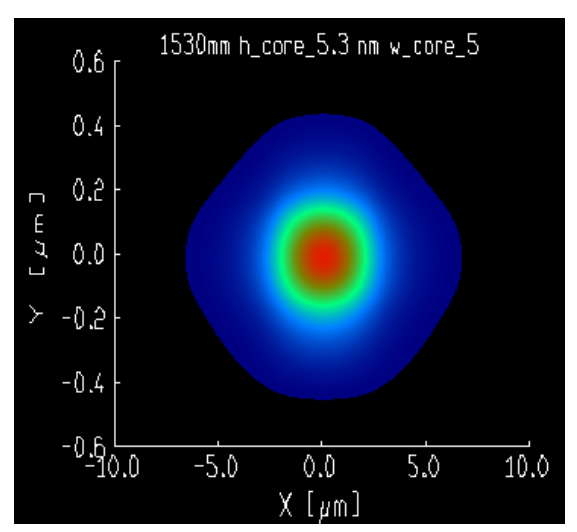

Fig. 61 - Resultado da simulação de um guia monomodo de $5 \mu \mathrm{m}$ para a guiamento de luz a $1530 \mathrm{~nm}$ 
Como se pode ver nas figuras 54 e 55, nas simulações para determinar os modos de guiamento, os resultados, para luz guiada de $632,8 \mathrm{~nm}$ mostraram que todos os guias são multímodo (TE). Comprimentos de onda maiores (1050 nm e $1530 \mathrm{~nm})$ resultaram em menos modos de guiamento, conforme pode ser visto nas figuras 56, 57, 58 e 59 nos três casos (632, 1080 e $1530 \mathrm{~nm}$ ). O número de modos tende a aumentar nos guias mais largos. Os valores de h_core são maiores nos guias de onda produzidos com maior fluxo de $\mathrm{SF}_{6}$, e também influem no guiamento.

Para guiamento monomodo, conforme visto anteriormente, os valores de h_core teriam que ser bem menores (para os comprimentos de 632,8, 1050 e 1530nm). Nestes casos os guias não poderiam possuir larguras superiores a $5 \mu \mathrm{m}$, pois as simulações indicaram espalhamento lateral do campo para guias de $7 \mu \mathrm{m}$. Menores fluxos de $\mathrm{SF}_{6}$, potências menores no plasma ou menor tempo de exposição poderiam fabricar guias com valores mostrados na tabela 11 .

Pelos motivos expostos acima, conclui-se que o material BWT é promissor para aplicações em dispositivos fotônicos. 


\section{Conclusões e perspectivas}

Por serem materiais relativamente pouco pesquisados, o que se traduz em literatura pouco extensa, foi preciso avaliar o material BWT por meio de várias caracterizações.

Foi assim desenvolvida tecnologia adequada para produção de filmes finos de BWT por sputtering, para nucleação de nanopartículas de ouro e para a produção de guias de onda passivos.

Guias de ondas passivos foram produzidos com filmes finos depositados por sputtering, empregando $\mathrm{O}_{2}$ e Ar, a partir de matriz BWT.

Para a fabricação dos guias de onda de BWT, todo o processo de fabricação, formado pela deposição, litografia até a remoção do fotorresiste, interfere na qualidade dos guias de onda produzidas. Faz-se necessário um controle de impurezas durante o processo de sputtering e no tratamento térmico, para evitar que elas se agreguem no material e interfiram no guiamento. A remoção adequada do fotorresiste permite a fabricação de guias mais lisos, pois a rugosidade é fator importante para o espalhamento da luz guiada.

Os testes de guiamento do BWT mostraram resultados apreciáveis, com índices de atenuação da luz guiada, em torno de $2 \mathrm{~dB} / \mathrm{cm}$ para guias de ondas com largura superior a 6 $\mu \mathrm{m}$, para comprimentos de onda de 632,8 e $1050 \mathrm{~nm}$. Guias mais estreitos apresentaram atenuações maiores.

Os resultados obtidos pelas simulações mostram guiamento multímodo (TE) para os comprimentos de onda de 632, 1050 e $1530 \mathrm{~nm}$. Para a fabricação de guias monomodo (TE), os valores de $h \_c o r e$, isto é, da corrosão parcial dos filmes, devem ser significativamente menores do que os obtidos com o emprego de 15 e $25 \mathrm{sccm}$ de $\mathrm{SF}_{6}$ durante a etapa de corrosão por RIE.

Conclui-se que os objetivos primordiais foram satisfatoriamente alcançados, isto é, a produção de filmes finos de BWT por sputtering com e sem nanopartículas metálicas, assim como os guias de ondas passivos. O material BWT pode ser usado para produção de guias de onda do tipo "rib" e apresenta-se como material promissor para a produção de dispositivos fotônicos, como os amplificadores ópticos, para guiamentos monomodo e multimodo. 


\section{Sugestões para trabalhos futuros}

Como sugestões para trabalhos futuros, podemos apresentar:

- Estudar as propriedades ópticas não-lineares dos filmes BWT;

- Obter a nucleação das NPs utilizando diversos tratamentos térmicos;

- Produzir guias de ondas BWT contendo NPs metálicas e dopadas com íons de $\mathrm{Er}^{3+}$, por meio de co-sputtering;

- Verificar o guiamento e os modos de propagação dos guias produzidos, empregando diversos comprimentos de onda. 


\section{Bibliografia}

[1] J. S. WZANG et al., Tellurite glass: a new candidate for fiber devices, Optical Materials, 3, 187, 1994.

[2] V. D. CACHO, Produção e caracterização de guias de onda de telureto e germanato para aplicações em optoeletrônica, Tese de Doutorado, Escola Politécnica, Universidade de São Paulo (2010).

[3] F. IZUMI, Deposição de filmes finos vítreos de telureto pela técnica 'sputtering', Trabalho de Conclusão de Curso, Faculdade de Tecnologia de São Paulo, São Paulo (2009).

[4] A. C. SEABRA, Deposição de filmes finos, Universidade de São Paulo, (2003).

[5] P. J. TATSCH, Deposição de filmes finos, V Oficina de Microeletrônica, FEEC/Unicamp, Brasil (1996).

[6] OHRING, M. - The Materials Science of Thin Films, Academic Press Inc., $2^{\mathrm{a}}$ ed., (2001)

[7] W. G. HORA, Produção e caracterização de filmes finos de $\mathrm{GeO}_{2}-\mathrm{PbO}$, Universidade de São Paulo (2008).

[8] Y. CHEN, Q. NIE, T. XU, S. DAI, X. WANG, X. SHEN, Journal of Non-Crystalline Solids, 354, 3468 (2007/2008).

[9] L. R. P. KASSAB, W. G. HORA, B. W. LOZANO, M. A. S. OlIVEIRA, and G. S. MACIEL, Journal of Optics Communications, 269, 2, 356 (2007)

[10] Y. RUAN, S. AFHSAR, T. M. MONRO, IEEE Photonics Journal, 3, 1, pg. 129 (2011).

[11] B. E. A. SALEH, M. C. TEICH, Fundamentals of Photonics, ISBN 0-471-2-1374-8, John Wiley \& Sons Inc., New York (1991).

[12] D. M. SILVA, Produção e caracterização de Filmes Finos Vítreos Dopados com $\mathrm{Er}^{3+} e$ contendo nanopartículas metálicas para a produção de guias de onda, Qualificação de Doutorado, Escola Politécnica, Universidade de São Paulo (2010). 
[13] T. A. ASSUMPÇÃO, Desenvolvimento de técnica para nucleação de nanopartículas metálicas em vidros de germanato dopados com ions de túlio para aplicações em dispositivos fotônicos, Dissertação de mestrado da Escola Politécnica da Universidade de São Paulo (2010)

[14] T. P. R. OLIVEIRA, Não linearidades de Terceira ordem de nanocolóides, filmes finos e vidros fotônicos, Universidade Federal de Pernambuco, Recife (2010).

[15] M. CARDONA, P. Y. YU, Fundamentals of semiconductors: Physics and Materials Properties, Springer (2005).

[16] T. UETA, Photon-phonon interaction in photonic crystals, IOP Conf. Series: Materials Science and Engineering, 10, 012103 (2010).

[17] F. GAN, L. XU, Photonic Glasses, World Scientific Publishing, Singapore (2006).

[18] N. V. NIKORONOV, G. T. PETROVSKI, Glass Phys, Chem., 25, 1, 16 (1998).

[19] R. R. GONÇALVES, Preparação e Caracterização de filmes óxidos contendo componentes opticamente ativos, Tese de doutorado, UNESP, Araraquara-SP (2001).

[20] B.E.A. SALEH, M. C. TEICH, Fundamentals of Photonics, Wiley-Interscience, 1 ed. (1991).

[21] D. O. CARVALHO, Estudo e desenvolvimento de guias de onda ARROW, com camadas anti-ressonantes de a-SiC:H e TiOx, para aplicação em dispositivos de óptica integrada, Dissertação (Mestrado), Escola Politécnica, Universidade de São Paulo (2008).

[22] H. NISHIHARA, M. HARUNA, T. SUHARA, Optical Integrated Circuits, New York, McGraw-Hill (1989).

[23] C. POLLOCK, Fundamentals of Optoelectronics, Chicago, Irwin (1995).

[24] F.LADOUCER, J. D. LOVE, Silica-based Buried Channel Waveguides and Devices, Chapman \& Hall (1996).

[25] A. YARIV, Coupled-Mode Theory for Guide-wave Optics, IEEE J. Quantum Electron (1973). 
[26] R. G. HUNSPERGER, Integrated Optics: Theory and Technology, Berlin, SpringerVerlag (1985).

[27] BBV - Programas registrados por BBV Software BV, Enschede, 1998.

[28] S. L. OLIVEIRA, L. A. O. NUNES, Investigação espectroscópica de sistemas vítreos dopados com $\mathrm{Tm}^{+3}, \mathrm{Ho}^{+3}$ e $\mathrm{Nd}^{+3}$. Dissertação de mestrado do Instituto de Física de São Carlos, Universidade de São Paulo, São Carlos (2004).

[29] E. LALLIER, Appl. Opt., 31, 5276 (1992).

[30] R. J. DERI, E. KAPON, L. M. SCHIAVONE, Applied Physics Letters, 51, 11, 789 (1987).

[31] A. L. SIARKOWSKI, Implantação de sensores ópticos integrados para aplicações em análises químicas e ambientais, Tese de doutorado da Escola Politécnica da Universidade de São Paulo (2007).

[32] H. LIBARDI, Estudo do acoplamento de luz a sistemas multicamadas: plasmons de superfície e guias de onda; Tese de Doutorado do Instituto de Física da Universidade Federal do Rio Grande do Sul, Porto Alegre (2005)

[33], H. A. ATWATER, The promise of plasmonics, Scientific American, April 2007, p.38, New York (2007).

[34] P. N. PRASAD, Nanophotonics, John Wiley \& Sons, Inc., New Jersey (2004).

[35] D. S. SILVA, Vidros de germanato com nanopartículas metálicas e semicondutoras dopados com terras-raras para aplicações em fotônica, Dissertação de Mestrado da Escola Politécnica da Universidade de São Paulo, São Paulo (2010).

[36] J. J. MOCK, M. BARBIC, D. R. SMITH, D. A. SCHULTZ, S. SCHULTZ, Journal of Chemical Physics, 116, 6755 (2002).

[37] R. A. PINTO, Síntese e caracterização de vidros de telureto dopados com íons de Eu ${ }^{3+} e$ $\mathrm{Tb}^{3+}$ com nanopartículas metálicas. Dissertação de Mestrado da Escola Politécnica da Universidade de São Paulo, São Paulo (2009). 
[38] L. BONTEMPO, S. G. SANTOS FILHO, A. SIARKOWSKI, L. R. P. KASSAB, ECS Transactions, 39, 1, 137, Pennigton, NJ (2011).

[39] W. KERN, Journal of Eletrochemical Society, 137, 6, 1887, San Diego, California (1990).

[40] W. KERN, D. A. PUOTINEM, RCA Review, 31, 187 (1970).

[41] S. M. SZE, L. E. KATZ, Oxidation; VLSI Technology, Singapura, McGraw-Hill Book Company, 131 (1983).

[42] S. WOLF, R. N. TAUBER, Silicon processing for the VLSI Era, 1 - Process Technology, Lattice Press (1986).

[43] C. A. R. de ARAÚJO, Manutenção e Caracterização do Equipamento Fotoalinhador AL4-2, Trabalho de Conclusão de Curso, Faculdade de Tecnologia de São Paulo, São Paulo (2007)

[44] W. S. RUSKA, Etching, Microelectronic Processing, McGraw-Hill, New York, (1987).

[45] A. NUNES, Corrosão por plasma de filmes de silício policristalino e nitreto de silício para tecnologia MEMS e CMOS, Dissertação de Mestrado, Faculdade de Engenharia Elétrica e Computação, Universidade Estadual de Campinas, Campinas-SP (2005)

[46] A. J. van ROOSMALEN, J. A. G. BAGGERMAN, S. J. H. BRADER, Dry Etching for VLSI, Plenum Press, New York (1991).

[47] J. D. PLUMMER, M. D. DEAL, P. B. GRIFFIN, Silicon VLSI Technology fundamental practice and modeling, Prentice Hall, Upper Saddle River (2000).

[48] C. CARDINAUD, M. C. PEIGNON, P. Y. TESSIER, Appl. Surf. Sci., 164, 72 (2000), [49] A. GRILL, Cold Plasma in Materials Fabrication, IEEE Press, New York (1994)

[50] Microscopia Eletrônica de Varredura, Apostila da disciplina PMI-2201 (Microscopia Eletrônica de Varredura e Microanálise Química), Escola Politécnica da USP, São Paulo. 
[51] A. F. PADILHA, Microscopia Eletrônica de Transmissão http://www.sorocaba.unesp.br/professor/jrborto2008S2/POSMAT/MET_notes.pdf (2008)

[52] B. D. CULLITY, Elements of X-Ray Diffraction, 2a ed., pg. 84-86, Addison-Wesley Publishing Company (1978).

[53] D. A. P. BULLA, Desenvolvimento e caracterização de Filmes Finos de Óxido de Silício e Nitreto de Silício para a Fabricação de Guias e Sensores Ópticos, Tese de Doutorado, Escola Politécnica da USP, São Paulo (1999).

[54] A. WITKOWSKA, J. RYBICKI, S. de PANFILIS, A. di CICCO, Journal of NonCrystalline Solids, 352, 4356 (2006).

[55] C. B. de ARAÚJO, E. L. FAlCÃO-FIlHO, A. HUMEAU, D. GUiCHAOUA, G. BOUDEBS, L. R. P. KASSAB, Appl. Phys. Lett., 87, 221904 (2005).

[56] NEYCO, Sputtering targets, 2, 69, Paris, France (2010)

[57] F. IZUMI, L. R. P. KASSAB, S. G. SANTOS FILHO, J. R. MARTINELLI, ECS Transactions, 39, 1, 117, Pennigton, NJ (2011).

[58] J. CHAMPARNAUD-MESJARD, B. Frit, A. Chagraoui, A. Tairi, Journal of Solid State Chemistry, 127, 248 (1996)

[59] B. FRIT, M. JAYMES, G. PEREZ, P. HAGENMULLER, Rev. Chim. Miner., 8, 453 (1971)

[60] L. DEMINA, V. A. DOLGIKH, Russ. J. Inorg. Chem. (Engl. Transl.), 29, 547 (1984)

[61] HANAWALT et al., Analytical Chemistry Journal, 10, 475 (1938)

[62] W. P. DAVEY, Zeitschrift fuer Kristallographie, Kristallgeometrie, Kristallphysik., Kristallchemie, 63, 316 (1926) 


\section{APÊNDICE A - Participações em eventos e publicações}

\section{Apresentações em Congressos}

- Fábio Izumi, Luciana Reyes Pires Kassab, Sebastião Gomes dos Santos Filho, José Roberto Martinelli, Production and Characterization of Bi2O3-WO3TeO2 thin films with Au nanoparticles for applications with micro and nanoelectronic devices - Apresentado em forma oral no "Symposium on Microelectronics Technology and Devices” em agosto de 2011, João Pessoa$P B$.

Publicações em periódicos internacionais

- Fábio Izumi, Luciana Reyes Pires Kassab, Sebastião Gomes dos Santos Filho, José Roberto Martinelli, Production and Characterization of Bi2O3-WO3TeO2 thin films with Au nanoparticles for applications with micro and nanoelectronic devices - ECS Transactions, 39, 1, 117-121, Pennigton, NJ (2011). (Aceito para publicação) 